Article

\title{
Design and Microwave Synthesis of New (5Z) 5-Arylidene-2-thioxo-1,3-thiazolinidin-4-one and (5Z) 2-Amino-5-arylidene-1,3-thiazol-4(5H)-one as New Inhibitors of Protein Kinase DYRK1A
}

\author{
Khadidja Bourahla ${ }^{1}$ (D), Solène Guihéneuf ${ }^{1}$, Emmanuelle Limanton ${ }^{1,2}$ D, Ludovic Paquin ${ }^{1,2}$, Rémy Le Guével ${ }^{3}$, \\ Thierry Charlier ${ }^{3,4}$, Mustapha Rahmouni ${ }^{5}$, Emilie Durieu ${ }^{6,7}$, Olivier Lozach ${ }^{7} \mathbb{D}$, François Carreaux ${ }^{1}$, \\ Laurent Meijer ${ }^{6}$ and Jean-Pierre Bazureau ${ }^{1,2, *}$
}

check for updates

Citation: Bourahla, K.; Guihéneuf, S.; Limanton, E.; Paquin, L.; Le Guével, R.; Charlier, T.; Rahmouni, M.; Durieu, E.; Lozach, O.; Carreaux, F.; et al. Design and Microwave Synthesis of New (5Z) 5-Arylidene-2thioxo-1,3-thiazolinidin-4-one and (5Z) 2-Amino-5-arylidene-1,3-thiazol$4(5 H)$-one as New Inhibitors of Protein Kinase DYRK1A. Pharmaceuticals 2021, 14, 1086. https://doi.org/10.3390/ ph14111086

Academic Editor: Daniela Catarzi

Received: 5 July 2021

Accepted: 22 October 2021

Published: 27 October 2021

Publisher's Note: MDPI stays neutral with regard to jurisdictional claims in published maps and institutional affiliations.

Copyright: (c) 2021 by the authors. Licensee MDPI, Basel, Switzerland. This article is an open access article distributed under the terms and conditions of the Creative Commons Attribution (CC BY) license (https:// creativecommons.org/licenses/by/ $4.0 /)$.
1 Institut des Sciences Chimiques de Rennes ISCR UMR CNRS 6226, Université de Rennes 1, Bât. 10A, Campus de Beaulieu, CS 74205, 263 Avenue du Général Leclerc, CEDEX, 35042 Rennes, France; bkhadije@yahoo.fr (K.B.); solene.guiheneuf@univ-rennes1.fr (S.G.); emmanuelle.limanton@univ-rennes1.fr (E.L.); ludovic.paquin@univ-rennes1.fr (L.P.); francois.carreaux@univ-rennes1.fr (F.C.)

2 S2Wave Platform, ScanMAT UMS 2001 CNRS, Université de Rennes 1, Bât. 10A, Campus de Beaulieu, CS 74205, 263 Avenue du Général Leclerc, CEDEX, 35042 Rennes, France

3 ImPACcell Platform, SFR Biosit, Université de Rennes 1, Bât. 8, Campus Villejean, 2 Avenue du Prof. Léon Bernard, CS 34317, CEDEX, 35043 Rennes, France; remy.leguevel@univ-rennes1.fr (R.L.G.); thierry.charlier@univ-rennes1.fr (T.C.)

4 Institut de Recherche en Santé, Environnement et Travail, IRSET Inserm U1085, Université de Rennes 1, 9 Avenue du Prof. Léon Bernard, 35000 Rennes, France

5 Laboratoire de Synthèse et de Catalyse, Université Ibn Khaldoun, Tiaret 14000, Algeria; m.rahmouni@mesrs.dz

6 Perha Pharmaceuticals \& ManRos Therapeutics, "From Sea to Pharmacy", Hôtel de Recherche, 29680 Roscoff, France; emilie.durieu@univ-nantes.fr (E.D.); meijer@perha-pharma.com (L.M.)

7 Protein Phosphorylation \& Human Disease Group, Station Biologique, 29680 Roscoff, France; olivier.lozach@univ-brest.fr

* Correspondence: jean-pierre.bazureau@univ-rennes1.fr; Tel.: +33-223-236-603

\begin{abstract}
Here, we report on the synthesis of libraries of new 5-arylidene-2-thioxo-1,3-thiazolidin-4ones 3 (twenty-two compounds) and new 2-amino-5-arylidene-1,3-thiazol-4(5H)-ones 5 (twenty-four compounds) with stereo controlled Z-geometry under microwave irradiation. The 46 designed final compounds were tested in order to determine their activity against four representative protein kinases (DYR1A, CK1, CDK5/p25, and GSK3 $\alpha / \beta$ ). Among these 1,3-thiazolidin-4-ones, the molecules (5Z) 5-(4-hydroxybenzylidene)-2-thioxo-1,3-thiazolidin-4-one 3e ( $\left.\mathrm{IC}_{50} 0.028 \mu \mathrm{M}\right)$ and $(5 Z)$ 5-benzo[1,3]dioxol-5-ylmethylene-2-(pyridin-2-yl)amino-1,3-thiazol-4(5H)-one 5s ( $\left.\mathrm{IC}_{50} 0.033 \mu \mathrm{M}\right)$ were identified as lead compounds and as new nanomolar DYRK1A inhibitors. Some of these compounds in the two libraries have been also evaluated for their in vitro inhibition of cell proliferation (Huh7 D12, Caco2, MDA-MB 231, HCT 116, PC3, and NCI-H2 tumor cell lines). These results will enable us to use the 1,3-thiazolidin-4-one core as pharmacophores to develop potent treatment for neurological or oncological disorders in which DYRK1A is fully involved.
\end{abstract}

Keywords: microwave; Knoevenagel condensation; sulphur/nitrogen displacement; 1,3-thiazolidin4-one; inhibition; protein kinase; DYRK1A; cell lines

\section{Introduction}

Protein kinases represent an important class of enzymes that play an important role in the regulation of various cellular processes. These enzymes catalyze proteinphosphorylation on serine, threonine, and tyrosine residues, which are frequently deregulated in human diseases. Only a small fraction of the 538 human kinases have been 
investigated as potential therapeutic targets [1]. Consequently, the search of protein kinase inhibitors represents an interesting target for the pharmaceutical industry for new therapeutic agents. Over the past decade, drug discovery has consisted of the empirical approach of random screening of large synthetic molecule libraries (or derivative of natural products) using high-throughput cell-based cytotoxicity assays to screening against clinical validated molecular targets. This approach has been successful in the area of oncology with small-molecule inhibitors of kinases, particularly in cancer progression and metastasis [2]. Among the 538 human kinases, DYRKs (dual-specificity tyrosine phosphorylation regulated kinases, 5 members) are a family of eukaryotic kinases that belong to a larger CMGC family of proline/arginine directed serine/threonine kinases. In this DYRK family, there are five mammalian subtypes $(1 \mathrm{~A}, 1 \mathrm{~B}, 2,3$, and 4$)$. The Dyrk1A gene is located within the human chromosome 21 Down Syndrome Critical Region (DSCR) [3]. According to recent literature, DYRK1A appears to be involved in various diseases, including Alzheimer's disease (AD), Down syndrome (DS) [4], and cancer [5-7], and many efforts have evolved over the last five years toward the identification of potent and selective DYRK1A inhibitors [8,9]. Few potent and selective Dyrks inhibitors have been described (Figure 1). As example, TG003 (I) has been demonstrated as a potent inhibitor of DYRK1A (12 nM), as well as DYRK1B (130 nM) [10,11]. In 2011, KH-CB19 (II) was identified as a specific and interesting inhibitor of DYRK1A (33 nM) [12]. Harmine (III), a plant-derived $\beta$-carboline alkaloid, is an ATP-competitive DYRK1A (55 nM) and DYRK1B (166 nM) [13]. A series of thiazolone-substituted aminopyrimidines $(\boldsymbol{I V})$ has been patented as DYRK1A inhibitors with potencies < $100 \mathrm{nM}$ [14]. A structure activity relationship (SAR) study around the quinazoline core was carried out at the NIH, and their efforts culminated in the identification of compound $(\boldsymbol{V})$ as a potent inhibitor of DYRK1A (62 nM) [15]. Revisiting the quinazoline chemistry, the same authors have also identified a new derivative (VI) (compound 46: $14 \mathrm{nM}$ ) [16]. Recently, a series of tricyclic pyrimidines (VII) was evaluated for their ability to inhibit DYRK1A $(0.16 \mathrm{nM})$ and DYRK1B [17]. Meridianines are marine alkaloids isolated from the South Atlantic tunicate Aplidium meridanium, and the synthesis of new analogues [18] substituted at the C-4 to C-7 position either by iodide atom or by nitro or amino groups induced the identification of meridianine 74 (VIII) as an interesting inhibitor of DYRK1A (compound 74: $66 \mathrm{nM}$ ). The chemical structure resemblance between the marine alkaloids meridianines and variolin $B$ encouraged the synthesis of a hybrid structure named meriolins [19], and compound (IX) provided good inhibition against DYRK1A (meriolin 2: $29 \mathrm{nM}$ ). The V-shaped 2-(pyridin-3-yl)-1H-indol-6-ol (X) was discovered to inhibit DYRK1A (60 nM) [20].

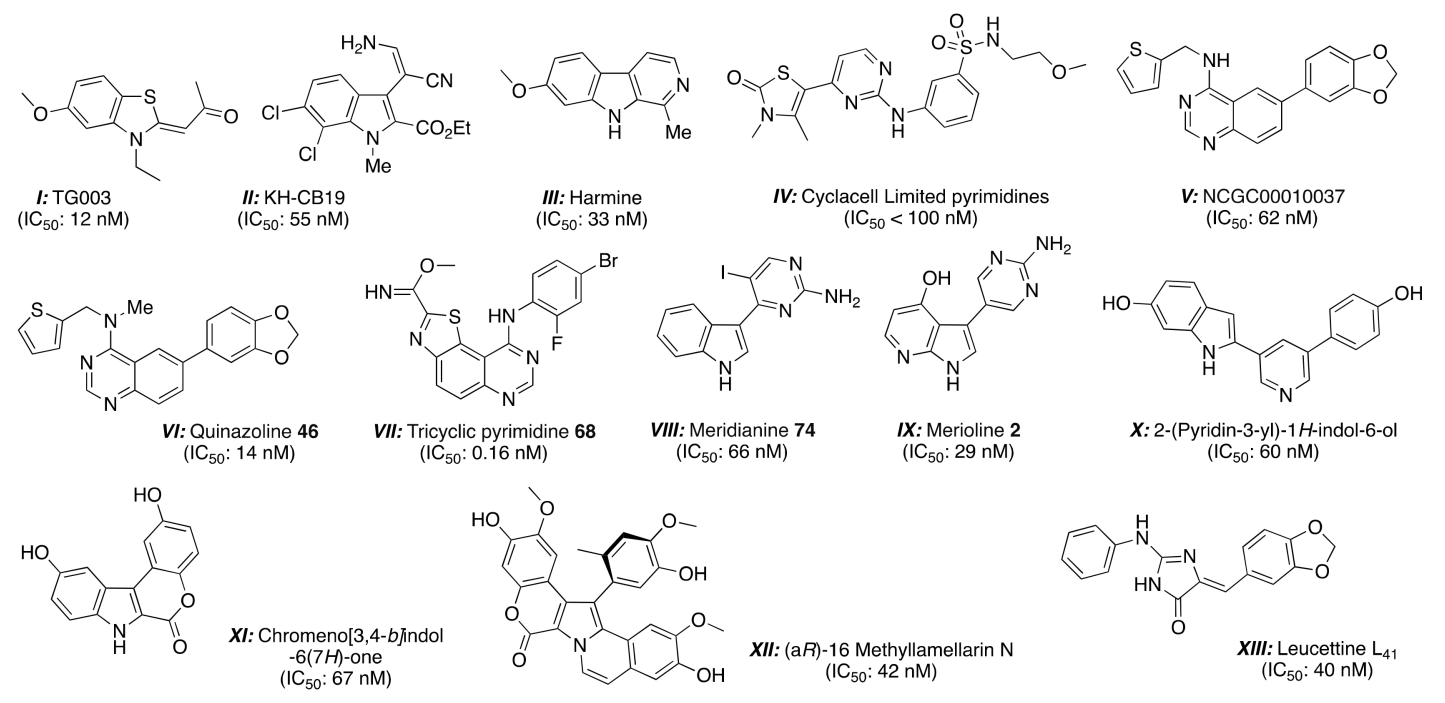

Figure 1. Reported small molecules as DYRK1A kinase inhibitors with their $\mathrm{IC}_{50}$ values in nM. 
Efforts for the synthetic preparation of new chromeno[3,4-b]indoles as Lamellarin D isosteres [21] have been developed, and compound (XI: $67 \mathrm{nM}$ ) emerged among the Lamellarin D derivatives. In 2013, the first successful synthesis and separation of the atropoisomeric $(\mathrm{a} R)$ - and $(\mathrm{aS})$-16-methyl lamellarins $\mathrm{N}$ and their different kinase inhibitory action against DYRK1A were reported [22]. The isomer (aR) (XII) showed potent but nonselective inhibition of DYRK1A ( $42 \mathrm{nM})$. The 2-amino imidazolone core is present in several marine sponges [23], such as polyandrocarpamines [24], dispacamides [25,26], aplysinopsine [27,28], clathridine [29], hymenialdisine [30-36], and Leucettamine B. This last alkaloid was isolated in 1993 from the marine calcareous sponge Leucetta microraphis Hæckel of the Argulpelu Reef in Palau [37], and no significant biological activity has been reported. From a biological screening, we discovered that the Leucettamine B analogues [38], named leucettines, exerted a selective inhibition toward protein kinases. A detailed structureactivity relationship (SAR) led to the identification of leucettine $\mathrm{L}_{41}$ (XIII) as good inhibitor of DYRKs and cdc2-like kinases (CLKs), which are involved in Alzheimer's disease/Down syndrome [39]. We also demonstrated that leucettine L41 inhibits DYRK1A and CLKs in a cellular context and displayed neuropropective properties [40].

The 2-amino 5-arylidene-5 $\mathrm{H}$-thiazol-4-ones and their 5-arylidene rhodanine precursors are a class of five-membered heterocyclic rings (FMHRs) considered as "privileged scaffolds" in the medicinal chemistry community [41], and considerable work has been published over decades about their chemistry and biology. Some of them exhibited antiinflammatory [42], anti-tumor effects [43], or have been identified as selective inhibitors of the dual specificity phosphatase (DSP) family [44].

Continuing in the effort to identify new DYRK1A inhibitors, we decided to explore the synthesis of new 5-arylidene- $5 \mathrm{H}$-thiazol-4-ones and new 5-arylidene-2-thioxo-1,3thiazolidin-4-ones. We also studied their effects on some protein kinases (DYRK1A, CK1, CDK5-p25, and GSK-3 $\alpha / \beta$ ) and on six representative tumor cell lines. Herein, we present the building of this thiazolone/thiazolidinone library, mostly carried out under microwave irradiation, and the biological activities of these compounds.

\section{Results and Discussion}

\subsection{Chemistry}

Retrosynthetic strategy toward new (5Z) 2-amino-5-arylidene-1,3-thiazol-4(5H)-ones $\mathbf{5 a}-\mathbf{q}$ is based on the use of secondary cyclic amines building blocks $4 \mathbf{a}-\mathbf{h}$ in sulfur/nitrogen displacement reaction and the use of various 2-thioxo-1,3-thiazolidin-4-ones 1a-i as starting platforms in Knoevenagel condensation (Figures 2 and 3).

\subsubsection{Synthesis of 5-Arylidene-2-thioxo-1,3-thiazolidin-4-one Library}

In order to synthesize a library of 5-arylidene-2-thioxo-1,3-thiazolidin-4-ones 3 (Scheme 1) for a systematic structure-activity relationship (SAR) study, we have examined the reactivity of 2-thioxo-1,3-thiazolidin-4-ones 1a-i with a series of various aromatic aldehydes $\mathbf{2 a -} \mathbf{p}$. We selected commercial aldehydes substituted by phenol function at various positions $(\mathbf{2} \mathbf{f}, \mathbf{2} \mathbf{g}, \mathbf{2} \mathbf{i}$, and $\mathbf{2 n}$ ) and/or methoxy groups ( $\mathbf{2 d}, \mathbf{e}, \mathbf{2 h})$ and cyclic ether function $(\mathbf{2 a}-\mathbf{c}, \mathbf{2 l}, \mathbf{2} \mathbf{\mathbf { o }}, \mathbf{2} \mathbf{p})$ to evaluate how the protic character and steric nature of the substituents on the phenyl ring will influence the biological activity of compounds 3 . We also examined the bio-isosteric replacement of the benzene ring of $\mathbf{3}$ with pyridine (2k) or benzofuran $(2 \mathrm{~m})$ moieties. Compounds $\mathbf{3}$ are designed to evaluate whether the $\mathrm{NH}$ function in position $N-1^{\prime}$ or a functional group with similar $\mathrm{H}-$ bond interactions will retain the activity.

For the 2-thioxo-1,3-thiazolidin-4-one platforms 1, rhodanine 1a, 2-(4-oxo-2-thioxothiazolidin-3-yl)acetic acid $\mathbf{1 b}$ and 3-amino rhodanine $\mathbf{1 d}$ are commercially available. Access to the 3-(4-oxo-2-thioxo-thiazolidin-3-yl)propanoic acid 1c could be accomplished by a recent patented protocol [45]. For introduction of the arylsulfonamide functionality on the rhodanine moiety in compound 1e, we used the Power's method [46]. Starting from commercial 3-amino-rhodanine $\mathbf{1 d}$, compounds $\mathbf{1} \mathbf{f}-\mathbf{i}$ were synthesized easily, according to a recent published procedure developed in our laboratory [47]. 

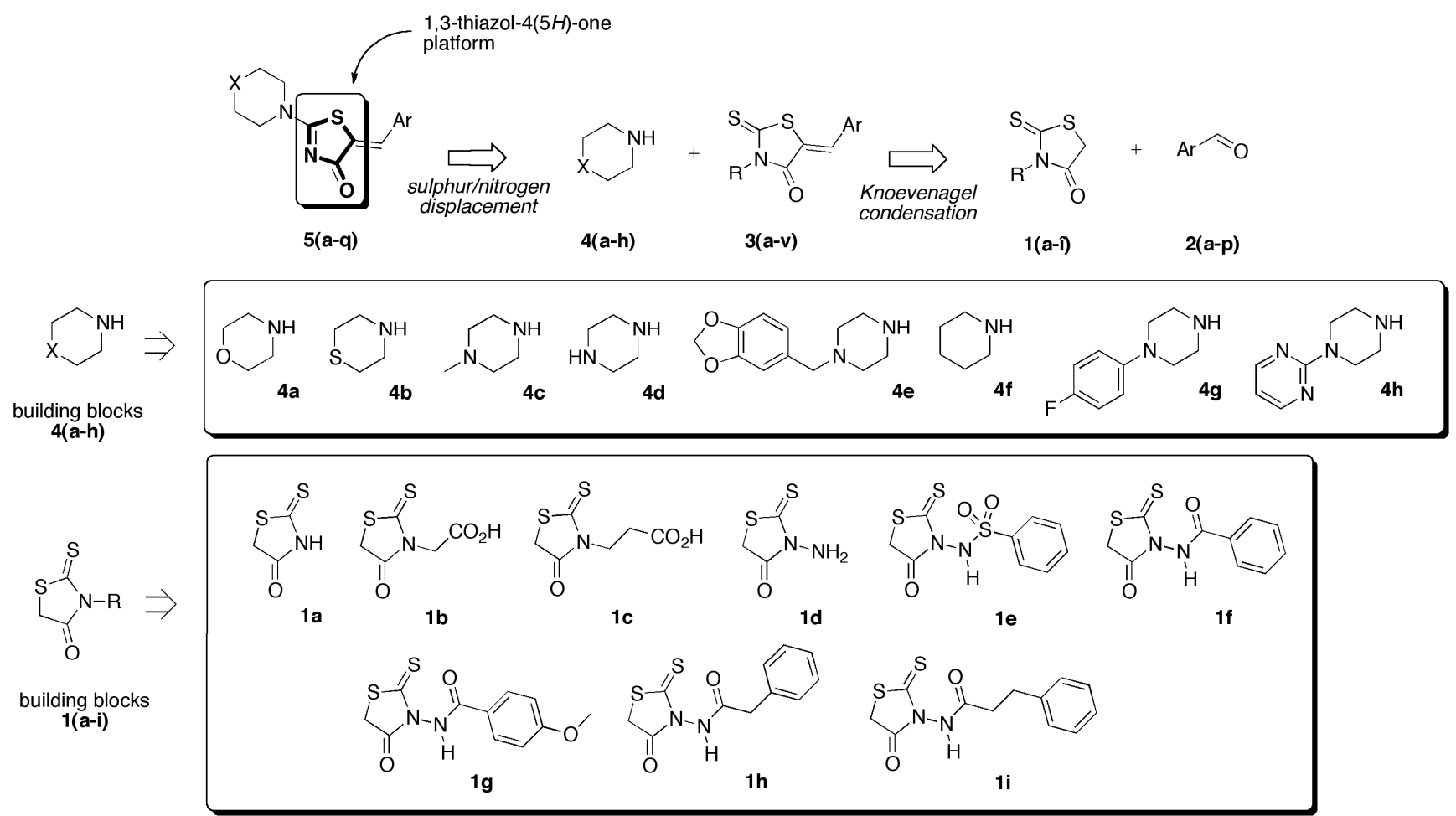

Figure 2. Retrosynthetic strategy toward new (5Z) 2-amino-5-arylidene-1,3-thiazol-4(5H)-ones 5a-q based on the use of secondary cyclic amines building blocks $4 \mathbf{a}-\mathbf{h}$ in sulfur/nitrogen displacement reaction and the use of various 2-thioxo-1,3thiazolidin-4-ones 1a-i as starting platforms in Knoevenagel condensation.

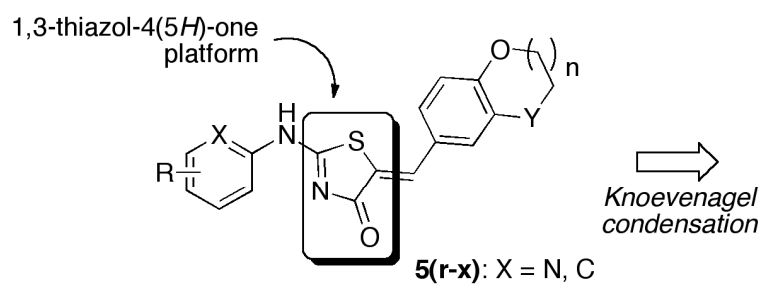

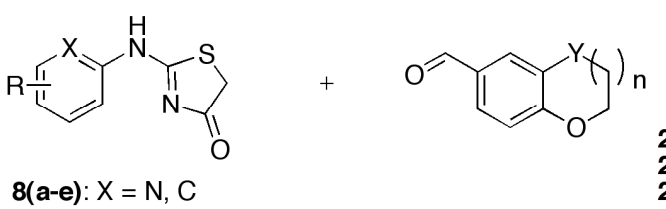

2a: $Y=O, n=0$
2b: $Y=C, n=0$

8(a-e): $X=N, C$

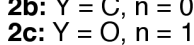

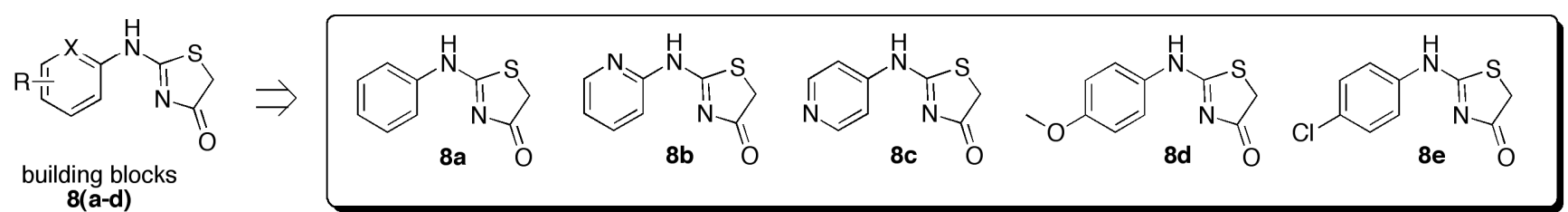

Figure 3. Retrosynthetic strategy toward new (5Z) 2-N-heteroarylamino-5-arylidene-1,3-thiazol-4(5H)-ones $5 \mathbf{r}-\mathbf{x}$ based on the use of aromatic aldehydes $\mathbf{2} \mathbf{a}-\mathbf{c}$ and various $2-N$-heteroarylamino-1,3-thiazolidin-4-one $\mathbf{8 a}-\mathbf{e}$ as other starting platforms in Knoevenagel condensations.

With the aim to develop a more efficient synthetic process for the synthesis of highly functionalized 5-arylidene rhodanines $3 \mathbf{a}-\mathbf{v}$ from the building blocks $\mathbf{1 a}-\mathbf{i}$ and $\mathbf{2} \mathbf{a}-\mathbf{p}$, microwave irradiation was employed to shorten the reaction times in comparison to conventional heating. For the reported methods, the Knoevenagel condensations have been realized in the presence of catalyst with various solvents: sodium acetate in glacial acetic acid [48] or in ethanol [46], piperidinium benzoate in toluene [49], tetrabutylammonium bromide in water [50], and piperidine in ethanol [51], using conventional heating in an oil bath. These older protocols suffer from one or more limitations, such as requiring harsh reaction conditions, low moderate yields, cumbersome experimental process, and long reaction time. Considering the latter aspect, we reasoned that microwave dielectric 
heating assisted chemistry might be an interesting approach for the synthesis of 5-arylidene rhodanine derivatives as potential biological molecules.

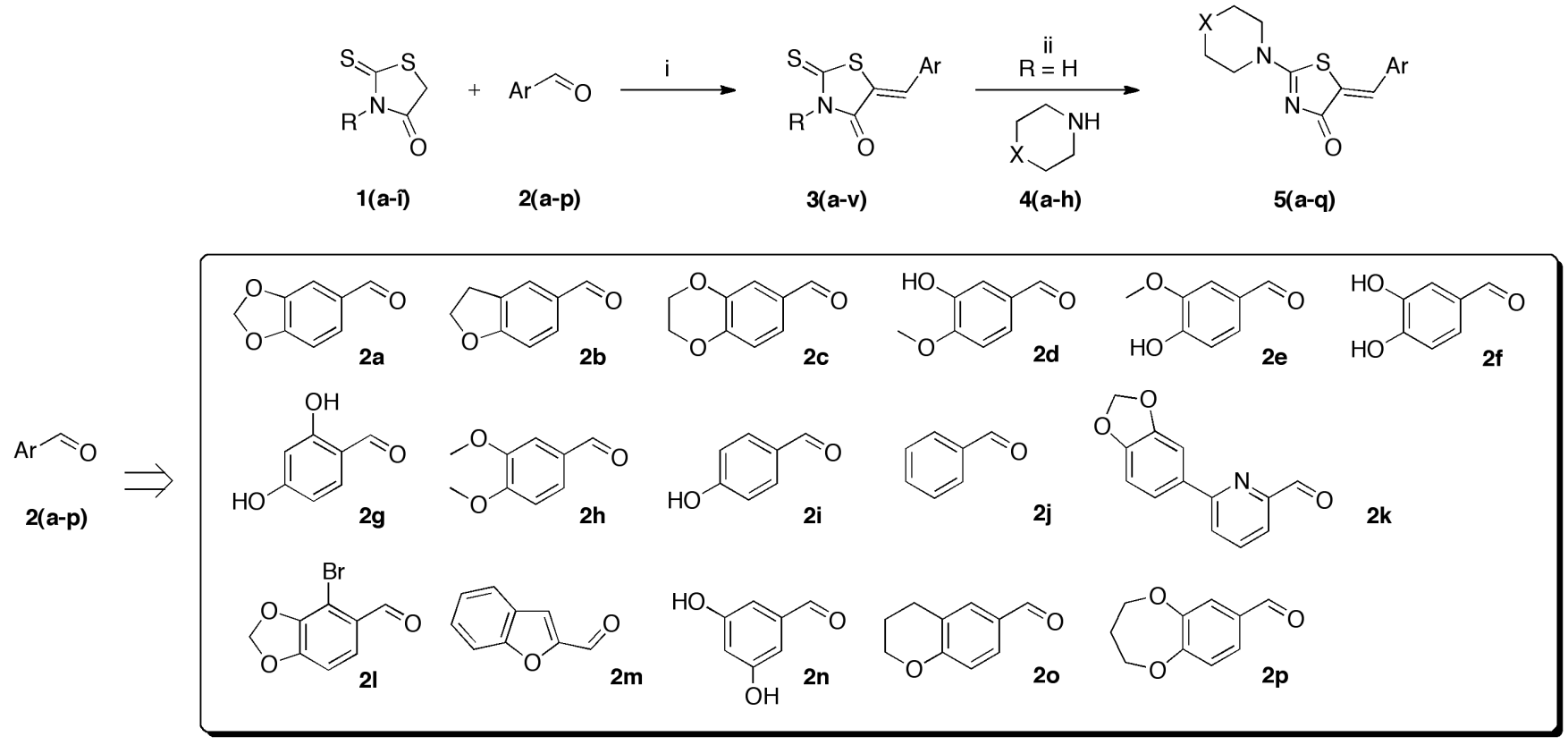

Scheme 1. General synthetic approach for the (5Z) 5-arylidene-2-thioxo-1,3-thiazolidin-4-one derivatives $3(\mathbf{a}-\mathbf{v})$ and for the (5Z) 2-amino-5-arylidene-1,3-thiazol-4(5H)-one 5a-q. Reagents and reaction conditions: (i) $n$ - $\mathrm{PrNH}_{2} 2 \mathrm{eq}, 80^{\circ} \mathrm{C}, 30 \mathrm{~min}$ for compounds 3a- 1 in open vessel using Synthewave ${ }^{\circledR} 402$ reactor for MWI; $\mathrm{Et}_{3} \mathrm{~N} 0.1$ eq or piperidine 0.1 eq or $\mathrm{AcONa} 1$ eq, AcOH 0.1-6.6 eq, $85-150{ }^{\circ} \mathrm{C}, 20-210 \mathrm{~min}$ for compounds $3 \mathbf{m}-\mathbf{v}$ in closed vessel using Explorer $24^{\circledR}$ CEM or Monowave ${ }^{\circledR}$ 300 Anton-Paar reactors for MWI. (ii) 4a-h 1.2 eq, MWI in Synthewave ${ }^{\circledR} 402$ microwave reactor, $80{ }^{\circ} \mathrm{C}, 20-60 \mathrm{~min}$.

For this study, we investigated the use of three microwave reactors: the Synthewave ${ }^{\circledR}$ 402 and the Explorer ${ }^{\circledR} 24$ apparatus with continuous irradiation power from 0 to $300 \mathrm{~W}$ and the Monowave ${ }^{\circledR} 300$ with continuous power from 0 to $800 \mathrm{~W}$. These three microwave irradiation reactors comprise a mono-mode microwave cavity that operates at a frequency of $2.45 \mathrm{GHz}$; the reaction temperature in the microwave cavity was controlled with a calibrated infrared sensor, and the microwave irradiation parameters (power and temperature) were monitored by a software package. For optimization of the experimental reaction conditions (selection of the appropriate reactor, reaction temperature and irradiation power), we have not realized a comparative study between these three reactors because we focused only our work on the microwave apparatus, which lead us to better results.

As can be seen in Table 1, the experiments revealed that the optimal reaction conditions for the 5-arylidene-2-thioxo-1,3-thiazolidin-4-ones 3a-1 were obtained in an open vessel after $60 \mathrm{~min}$ at $80{ }^{\circ} \mathrm{C}$ (with a power of $90 \mathrm{~W}$ ) in the Synthewave ${ }^{\circledR} 402$ apparatus with a stoichiometry of 1/1-4 of aryl aldehyde 2 and the volatile propylamine in order to be able to develop one-pot tandem reactions (aldimine synthesis/Knoevenagel condensation) [52]. According to this microwave method, the compounds $3 \mathbf{a}-\mathbf{1}$ were synthesized in yields ranging from 62 to $89 \%$. For the other compounds, $3 \mathbf{m}, 3 \mathbf{n}$, and $\mathbf{3 p}-\mathbf{v}$, we screened a range of another reaction condition parameters in a closed vessel (a tube sealed with a snap cap) with the appropriate microwave reactors. With the conditions shown in Table 1, AcONa ( 0.1 or $1-1.2 \mathrm{eq})$ and $0.1 \mathrm{eq}$ of piperidine in glacial acetic acid (0.1-6.6 eq) were identified to execute the Knoevenagel reactions in good yields (62-98\% excepted for 3p). Unfortunately, we are not able to use this protocol for the preparation of compound 2o. It was obtained in moderate yield (2o: 26\%) using classical heating in an oil bath. The structures of the desired 5-arylidene-2-thioxo-1,3-thiazolidin-4-ones $3 \mathbf{3 a - v}$ were substantiated by ${ }^{1} \mathrm{H},{ }^{13} \mathrm{C}$ NMR (Supplementary Materials), and HRMS analyses, and only the thermodynamically more stable Z-isomers were obtained [50]. 
Table 1. Results for the preparation under microwave irradiation of (5Z) 5-arylidene-2-thioxo-1,3-thiazolidin-4-one derivatives 3a-v from aromatic aldehydes $\mathbf{2} \mathbf{a}-\mathbf{p}$ and 2-thioxo-1,3-thiazolidin-4-ones 1a-i.

\begin{tabular}{|c|c|c|c|c|c|c|c|}
\hline & \multirow[b]{2}{*}{ Compound 3} & \multirow[b]{2}{*}{ Reagents } & \multicolumn{4}{|c|}{ Reactions Conditions Used under Microwave ${ }^{a}$} & \multirow[b]{2}{*}{$\begin{array}{l}\text { Yield }{ }^{b} \text { of } \\
\quad 3(\%)^{d}\end{array}$} \\
\hline & & & $\begin{array}{c}\text { Starting } \\
\text { Aldehyde } 2\end{array}$ & $\begin{array}{c}\text { Reaction } \\
\text { Temp. }\left({ }^{\circ} \mathrm{C}\right)\end{array}$ & $\begin{array}{c}\text { Reaction } \\
\text { Time (min.) }\end{array}$ & Power (W) & \\
\hline $3 a$ & & $n-\mathrm{PrNH}_{2} 2 \mathrm{eq}$ & $2 a$ & 80 & 60 & $90^{c}$ & 79 \\
\hline $3 b$ & & $n-\mathrm{PrNH}_{2} 2 \mathrm{eq}$ & $2 d$ & 80 & 60 & $90^{c}$ & 81 \\
\hline $3 c$ & & $n-\mathrm{PrNH}_{2} 4 \mathrm{eq}$ & $2 e$ & 80 & 60 & $90^{c}$ & 80 \\
\hline $3 d$ & & $n-\mathrm{PrNH}_{2} 2 \mathrm{eq}$ & $2 \mathrm{~h}$ & 80 & 60 & $90^{c}$ & 83 \\
\hline $3 e$ & & $n-\mathrm{PrNH}_{2} 2 \mathrm{eq}$ & $2 \mathbf{i}$ & 80 & 40 & $90^{c}$ & 79 \\
\hline $3 f$ & & $n-\mathrm{PrNH}_{2} 2 \mathrm{eq}$ & $2 c$ & 80 & 60 & $90^{c}$ & 89 \\
\hline $3 g$ & & $n-\mathrm{PrNH}_{2} 2 \mathrm{eq}$ & $2 b$ & 80 & 60 & $90 \mathrm{c}$ & 79 \\
\hline $3 h$ & & $n-\mathrm{PrNH}_{2} 2 \mathrm{eq}$ & $2 k$ & 80 & 60 & $90^{c}$ & 68 \\
\hline $3 \mathbf{i}$ & & $n-\mathrm{PrNH}_{2} 1$ eq & 21 & 80 & 60 & $90^{c}$ & 70 \\
\hline $3 \mathbf{j}$ & & $n-\mathrm{PrNH}_{2} 2 \mathrm{eq}$ & $2 f$ & 80 & 60 & $90^{c}$ & 79 \\
\hline $3 k$ & & $n-\mathrm{PrNH}_{2} 2 \mathrm{eq}$ & $2 n$ & 80 & 60 & $90^{c}$ & 79 \\
\hline 31 & & $n-\mathrm{PrNH}_{2} 2 \mathrm{eq}$ & $2 m$ & 80 & 60 & $90^{c}$ & 62 \\
\hline $3 m$ & & $\begin{array}{c}\mathrm{AcONa} 1.2 \mathrm{eq} \\
\mathrm{AcOH} 1.2 \mathrm{eq}\end{array}$ & 20 & 140 & 20 & $-e$ & 93 \\
\hline
\end{tabular}


Table 1. Cont.

\begin{tabular}{|c|c|c|c|c|c|c|c|}
\hline & \multirow[b]{2}{*}{ Compound 3} & \multirow[b]{2}{*}{ Reagents } & \multicolumn{4}{|c|}{ Reactions Conditions Used under Microwave ${ }^{a}$} & \multirow{2}{*}{$\begin{array}{c}\text { Yield }^{b} \text { of } \\
3(\%)\end{array}$} \\
\hline & & & $\begin{array}{c}\text { Starting } \\
\text { Aldehyde } 2\end{array}$ & $\begin{array}{c}\text { Reaction } \\
\text { Temp. }\left({ }^{\circ} \mathrm{C}\right)\end{array}$ & $\begin{array}{c}\text { Reaction } \\
\text { Time (min.) }\end{array}$ & Power (W) & \\
\hline $3 n$ & & $\begin{array}{l}\mathrm{AcONa} 1.2 \mathrm{eq} \\
\mathrm{AcOH} 1.2 \mathrm{eq}\end{array}$ & $2 p$ & 140 & 30 & $-e$ & 94 \\
\hline 30 & & $\begin{array}{c}\mathrm{Et}_{3} \mathrm{~N} 0.1 \mathrm{eq} \\
\mathrm{AcOH} 0.1 \mathrm{eq} \\
\mathrm{AcOEt}\end{array}$ & $2 a$ & 85 & 210 & $-f$ & 26 \\
\hline $3 p$ & & $\begin{array}{c}\text { piperidine } 0.1 \mathrm{eq} \\
\mathrm{AcOH} 0.1 \mathrm{eq}\end{array}$ & $2 a$ & 150 & 20 & $200^{d}$ & 27 \\
\hline $3 q$ & & $\begin{array}{l}\mathrm{AcONa} 1 \mathrm{eq} \\
\mathrm{AcOH} 6.6 \mathrm{eq}\end{array}$ & $2 a$ & 120 & 20 & $100^{d}$ & 98 \\
\hline $3 r$ & & $\begin{array}{l}\mathrm{AcONa} 1 \mathrm{eq} \\
\mathrm{AcOH} 6.6 \mathrm{eq}\end{array}$ & $2 a$ & 120 & 20 & $-e$ & 68 \\
\hline $3 s$ & & $\begin{array}{l}\mathrm{AcONa} 1 \mathrm{eq} \\
\mathrm{AcOH} 6.6 \mathrm{eq}\end{array}$ & $2 a$ & 120 & 20 & $100^{d}$ & 83 \\
\hline $3 t$ & & $\begin{array}{c}\text { piperidine } 0.1 \mathrm{eq} \\
\mathrm{AcOH} 0.1 \mathrm{eq}\end{array}$ & $2 a$ & 150 & 20 & $200^{d}$ & 64 \\
\hline $3 \mathbf{u}$ & & $\begin{array}{l}\mathrm{AcONa} 0.1 \mathrm{eq} \\
\mathrm{AcOH} 0.1 \mathrm{eq}\end{array}$ & $2 a$ & 150 & 20 & $-e$ & 72 \\
\hline $3 v$ & & $\begin{array}{c}\text { piperidine } 0.1 \mathrm{eq} \\
\mathrm{AcOH} 0.1 \mathrm{eq}\end{array}$ & $2 a$ & 150 & 20 & $-e$ & 62 \\
\hline
\end{tabular}

\footnotetext{
${ }^{a}$ Microwave irradiation (MWI) of the reaction mixture was realized in an open glass microwave reactor or in tube sealed with a snap cap (closed vessel). ${ }^{b}$ Isolated yield after work up, crystallization, and washing using appropriate solvent. ${ }^{c}$ Synthewave ${ }^{\circledR} 402$ (Merck Eurolab Prolabo France) used as microwave reactor (Power max.: $300 \mathrm{~W}$ ). Reaction under microwave was realized in an open glass reactor. ${ }^{d}$ Explorer $^{\circledR} 24$ (CEM $\mu$ Wave France) used as a microwave reactor (Power max.: $300 \mathrm{~W}$ ). Reaction under microwave was realized in a tube sealed with a snap cap. ${ }^{e}$ Monowave ${ }^{\circledR} 300$ (Anton Paar France) used as a microwave reactor (Power max.: 800 W). Reaction under microwave was realized in a tube sealed with a snap cap. ${ }^{f}$ Compound $3 \mathbf{o}$ was synthesized in an oil bath, and initial attempts to obtain $3 \mathbf{o}$ under microwave irradiation were unsuccessful.
}

\subsubsection{Synthesis of (5Z) 2-Amino-5-arylidene-1,3-thiazolidin-4-one Library}

With the compounds $3 \mathbf{a}-\mathbf{v}$ in hand, we investigated the preparation of novel 2-amino5-arylidene-1,3-thiazolidin-4-ones 5, according to Scheme 1. Transformation of 5-arylidenerhodanine derivatives 3 into their 2-amino-5-arylidene-1,3-thiazolidin-4-ones 5 involved a sulfur/nitrogen displacement in the presence of a primary amine [53] or a secondary amine [54]. Commonly, the synthesis of 2-amino-1,3-thiazol-4-one involved activation of the $\mathrm{C}=\mathrm{S}$ bond of the starting 5 -arylidene rhodanine, and reaction with an halogenoalcane (i.e., EtI or MeI) potentially gave the desired $S$-alkyl-5-arylidene-1,3-thiazol-4(5H)-one, together with the $\mathrm{N}$-alkyl-5-arylidene rhodanine derivative, as a side product [55]. In this context, we preferred to directly investigate the sulfur/nitrogen displacement in a faster and more efficient way by using microwave dielectric heating for the synthesis of targeted compounds 5 from the intermediate 3 and a variety of polar cyclic secondary amines 4 . In order to obtain interesting information for the structure-activity relationship (SAR) study 
on these compounds 5 as inhibitors of the protein kinase DYRK-1A, compounds 5 were designed to evaluate how the electrostatic and steric nature of the substituents on the phenyl ring and/or the presence of various amino moieties in position C-2 will influence the biological activity. For this study, we have employed eight polar cyclic secondary amines $\mathbf{4} \mathbf{a}-\mathbf{h}$ as elements of the second point of molecular diversity for the construction of compounds 5. After a preliminary screening of the microwave irradiation conditions (open or closed vessel mode, temperature, power of irradiation, time), the experiments revealed the optimal ratio of $\mathbf{3 / 4}$ under microwave irradiation was obtained with $1.5 \mathrm{eq}$ of amino reagent 5 using the "open vessel mode". For the other parameters (temperature: 80-100 ${ }^{\circ} \mathrm{C}$, power: $80-150 \mathrm{~W}$, time: $20-60 \mathrm{~min}$ ), the results for each product 5 are presented in Table 2. To verify the versatility and efficiency of this open vessel microwave protocol, different starting 5-arylidene rhodanine derivatives 3 and commercially available cyclic secondary amines $\mathbf{4} \mathbf{a}-\mathbf{h}$ were used as building blocks to generate a collection of seventeen new 2-amino-5-arylidene-1,3-thiazolidin-4-ones 5a-q: in all cases, the products were easily isolated in good to high yields (72-96\%) after a simple precipitation from EtOH. The structure identification of all these new compounds 5 were based on the ${ }^{1} \mathrm{H}$ and ${ }^{13} \mathrm{C}$ assignments and was performed extensive 1D and 2D NMR spectroscopy. For the exocyclic double bond $(\mathrm{CH}=\mathrm{C})$ of all the 2-amino-5-arylidene-1,3-thiazolidin-4-ones 5, ${ }^{1} \mathrm{H} \mathrm{NMR}$ spectra show only one signal for the methylene proton $(\mathrm{CH}=)$ in the range of 7.56-7.61 ppm at lower field values than those expected or previously reported in the literature for the $E$-isomers which, strongly indicates that the compounds $\mathbf{5 a - q}$ have the Z-configuration because of the high degree of thermodynamic stability of this isomer [56].

Table 2. Results for the solvent-free synthesis under microwave irradiation of (5Z) 2-amino-5-arylidene-1,3-thiazol-4(5H)-one derivatives $\mathbf{5 a -} \mathbf{q}$ by sulfur/nitrogen displacement reaction from (5Z) 5-arylidene-2-thioxo-1,3-thiazolidin-4-one derivatives $\mathbf{3}$ and cyclic secondary amines $\mathbf{4 a}-\mathbf{h}$.

\begin{tabular}{|c|c|c|c|c|c|c|c|}
\hline & \multirow[t]{2}{*}{ Compound 5} & \multirow[t]{2}{*}{ Starting Compound 3} & \multirow{2}{*}{$\begin{array}{c}\text { Starting } \\
\text { Compound } 4\end{array}$} & \multicolumn{3}{|c|}{$\begin{array}{c}\text { Reactions Conditions Used under } \\
\text { Microwave } \\
{ }^{a}\end{array}$} & \multirow{2}{*}{$\begin{array}{l}\text { Yield }{ }^{b} \text { of } \\
\quad 5(\%)\end{array}$} \\
\hline & & & & Temp. $\left({ }^{\circ} \mathrm{C}\right)$ & Time (min.) & Power $^{c}(W)$ & \\
\hline $5 a$ & & $3 a$ & & 80 & 20 & 80 & 96 \\
\hline $5 b$ & & $3 d$ & & 80 & 25 & 80 & 64 \\
\hline $5 c$ & & $3 \mathbf{b}$ & & 80 & 20 & 80 & 88 \\
\hline $5 d$ & & $3 c$ & & 80 & 20 & 80 & 86 \\
\hline $5 e$ & & $3 a$ & & 80 & 60 & 80 & 78 \\
\hline $5 f$ & & $3 a$ & & 80 & 60 & 80 & 84 \\
\hline
\end{tabular}


Table 2. Cont.

\begin{tabular}{|c|c|c|c|c|c|c|c|}
\hline & \multirow[t]{2}{*}{ Compound 5} & \multirow[t]{2}{*}{ Starting Compound 3} & \multirow{2}{*}{$\begin{array}{c}\text { Starting } \\
\text { Compound } 4\end{array}$} & \multicolumn{3}{|c|}{$\begin{array}{l}\text { Reactions Conditions Used under } \\
\text { Microwave } \\
\text { Mi }^{-}\end{array}$} & \multirow{2}{*}{$\begin{array}{l}\text { Yield }{ }^{b} \text { of } \\
\quad 5(\%)\end{array}$} \\
\hline & & & & Temp. $\left({ }^{\circ} \mathrm{C}\right)$ & Time (min.) & Power $^{c}(\mathrm{~W})$ & \\
\hline $5 g$ & & & & 80 & 30 & 80 & 80 \\
\hline $5 \mathrm{~h}$ & & & & 80 & 35 & 80 & 78 \\
\hline $5 \mathbf{i}$ & & & & 80 & 20 & 80 & 80 \\
\hline $5 \mathbf{j}$ & & & & 100 & 30 & 80 & 75 \\
\hline $5 k$ & & & & 120 & 20 & 150 & 72 \\
\hline 51 & & & & 100 & 25 & 150 & 80 \\
\hline $5 \mathrm{~m}$ & & & & 80 & 20 & 90 & 80 \\
\hline $5 n$ & & & & 80 & 20 & 90 & 84 \\
\hline 50 & & & & 80 & 20 & 90 & 86 \\
\hline $5 p$ & & & & 80 & 20 & 90 & 88 \\
\hline $5 q$ & & & & 80 & 20 & 90 & 80 \\
\hline
\end{tabular}

${ }^{a}$ Microwave irradiation (MWI) of the reaction mixture was realized in an open glass microwave reactor. ${ }^{b}$ Isolated yield after work up, crystallization, and washing using appropriate solvent. ${ }^{c}$ Synthewave ${ }^{\circledR} 402$ (Merck Eurolab Prolabo Fr) used as a microwave reactor (Power max.: $300 \mathrm{~W}$ ).

To extend the molecular diversity on the C-2 position of the rhodanine platform, we have also examined introduction of aromatic primary amine (i.e., aniline, C-substituted aniline, amino pyridine, etc.) using the microwave dielectric heating protocol for sulfur/nitrogen displacement from 5-arylidene-2-thioxo-1,3-thiazolidin-4-one 3 and appropriate aromatic primary amine. After screening of the microwave irradiation conditions 
based on the reaction temperature $\left(90-160{ }^{\circ} \mathrm{C}\right)$, the power for irradiation $(90-150 \mathrm{~W})$, the reaction time (30-60 $\mathrm{min})$, the use of polar or non-polar solvent (EtOH, hexane), the use of open or closed vessel mode, and the ratio of the reagents (ratio 3/aromatic amine: 1-3.5), it was not possible to obtain the desired 2- $\mathrm{N}$-arylamino-5-arylidene-1,3-thiazolidin-4-one 5 after analysis of the crude reaction mixture by ${ }^{1} \mathrm{H}$ NMR. Accordingly, we decided to drop this synthetic strategy for access to 2- $\mathrm{N}$-arylamino-5-arylidene-1,3-thiazolidin-4-one and to focus now on the use of 2-N-heteroarylamino-1,3-thiazolidin-4-ones 8a-e in Knoevenagel condensation (Scheme 2). The designed compounds $8 \mathbf{a}-\mathbf{e}$ were easily prepared from $\mathrm{N}$-aryl thiourea $\mathbf{6 a}-\mathbf{d}$ and ethyl bromoacetate according to a protocol developed in our laboratory [55]. As shown in Table 3, the "closed vessel" microwave irradiation procedure involved the use of piperidine ( $0.1 \mathrm{eq})$ or $\mathrm{AcONa}(0.1-1 \mathrm{eq})$ in glacial acetic acid for the synthesis of 2- $\mathrm{N}$-heteroarylamino-5-arylidene-1,3-thiazolidin-4-one $5 \mathbf{r}-\mathbf{x}$ from the building blocks 8a-e and aromatic aldehydes $2 \mathbf{a}-\mathbf{c}$ after $20-40 \mathrm{~min}$ at 120 or $150{ }^{\circ} \mathrm{C}$ with a power of 100-200 W. This protocol is also very simple to execute because the desired products $\mathbf{5 r}-\mathbf{x}$ were isolated after crystallization from ethanol in moderate to good yields (34-90\%). The expected Z-geometry of these compounds 5 was confirmed by the chemical shift of the exocyclic methylene proton $(\mathrm{CH}=)$ obtained in ${ }^{1} \mathrm{H}$ NMR [56].



6(a-d): $X=N, C$

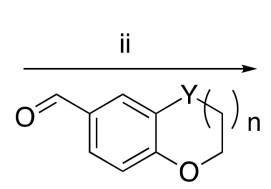

2a: $Y=O, n=0$

2b: $Y=C, n=0$

2c: $Y=O, n=1$

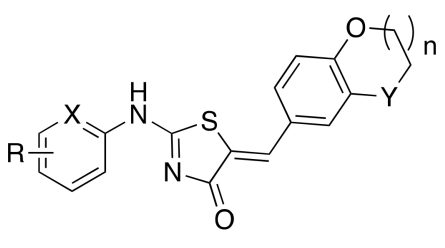

$5(r-x): X=N, C$

Scheme 2. General synthetic approach for the (5Z) 2- $N$-heteroarylamino-5-arylidene-1,3-thiazol-4(5H)-one derivatives $5 \mathbf{r}-\mathbf{x}$ from the starting 2-N-heteroarylamino-1,3-thiazolidin-4-one 8a-e and aromatic aldehydes 3(a-c). Reagents and reaction conditions: (i) $71.3 \mathrm{eq}, \mathrm{EtOH}, 55^{\circ} \mathrm{C}, 3.5-22 \mathrm{~h}$; (ii) piperidine 0.1 eq or AcONa 0.1 eq, $\mathrm{AcOH} 0.1-6.6$ eq, $120-150{ }^{\circ} \mathrm{C}$, MWI in closed vessel (Explorer $24{ }^{\circledR} \mathrm{CEM} \mu$ Wave reactor), 20-40 min.

\subsection{Biological Activities}

The twenty-two (5Z) 5-arylidene-2-thioxo-1,3-thiazolidin-4-ones 3a-v and the twentyfour (5Z) 2-amino-5-arylidene-1,3-thiazolidin-4(5H)-ones $\mathbf{5 a - \mathbf { x }}$ were evaluated against four different and representative in vitro kinase assays DYRK1A (dual specificity tyrosine phosphorylation regulated kinase), CK1 $\delta / e$ (caseine kinase 1), CDK5/p25 (cyclin dependant kinase) [57], and GSK3 $\alpha / \beta$ (glycogen synthase kinase 3) to evaluate their inhibition potency. These kinases were purified and assayed in the presence of $15 \mu \mathrm{M}$ ATP and appropriate substrates (GS-1 peptide for GSK3 $\alpha / \beta$, CKS peptide for CK $1 \delta / \varepsilon$, histone H1 for CDK5/p25) as previously described [39]. All the compounds were initially tested at a $10 \mu \mathrm{M}$ concentration. Those displaying less than $50 \%$ inhibition were considered inactive. Compounds showing more than $50 \%$ inhibition at $10 \mu \mathrm{M}$ were next evaluated over a wide range of concentrations (usually $0.01,5$ and $10 \mu \mathrm{M}$ ), and the $\mathrm{IC}_{50}$ values were calculated from the dose-responses curves (Sigma-plot). (R)-Roscovitine and harmine (a natural $\beta$-carboline alkaloid known to be a potent inhibitor of DYRK1A [12]) were also used as positive control, and its $\mathrm{IC}_{50}$ values were compared with those obtained for the compounds 3 and 5. Results are summarized, respectively, in Table 4 for the (5Z) 5-arylidene-2-thioxo-1,3thiazolidin-4-one $3 \mathbf{a}-\mathbf{v}$, and Table 5 for the (5Z) 2-amino-5-arylidene-1,3-thiazol-4(5H)-one $5 \mathbf{a}-\mathbf{x}$. 
Table 3. Results for the preparation under microwave irradiation of (5Z) 2- $N$-heteroarylamino-5-arylidene-1,3-thiazol-4(5H)one derivatives $\mathbf{5} \mathbf{r}-\mathbf{x}$ from 2-N-heteroarylamino-thiazolidin-4-one $\mathbf{8 a - e}$ and aromatic aldehydes $\mathbf{3 a}-\mathbf{c}$.

\begin{tabular}{|c|c|c|c|c|c|c|}
\hline & \multirow[b]{2}{*}{ Compound 5} & \multicolumn{4}{|c|}{ Reaction Conditions Used under Microwave $^{a}$} & \multirow[b]{2}{*}{$\begin{array}{l}\text { Yield }{ }^{c} \text { of } \\
\quad 5(\%)\end{array}$} \\
\hline & & Reagents & $\begin{array}{l}\text { Reaction } \\
\text { Temp. }\left({ }^{\circ} \mathrm{C}\right)\end{array}$ & $\begin{array}{c}\text { Reaction } \\
\text { Time (min.) }\end{array}$ & Power $^{b}(\mathrm{~W})$ & \\
\hline $5 \mathbf{r}$ & & $\begin{array}{c}\text { piperidine } 0.1 \mathrm{eq} \\
\mathrm{AcOH} 0.1 \mathrm{eq}\end{array}$ & 150 & 20 & 200 & 34 \\
\hline $5 s$ & & $\begin{array}{l}\mathrm{AcONa} 0.1 \mathrm{eq} \\
\mathrm{AcOH} 6.6 \mathrm{eq}\end{array}$ & 120 & 20 & 100 & 90 \\
\hline $5 t$ & & $\begin{array}{c}\mathrm{AcONa} 0.1 \mathrm{eq} \\
\mathrm{AcOH} 6.6 \mathrm{eq}\end{array}$ & 120 & 40 & 100 & 43 \\
\hline $5 \mathbf{u}$ & & $\begin{array}{l}\mathrm{AcONa} 0.1 \mathrm{eq} \\
\mathrm{AcOH} 6.6 \mathrm{eq}\end{array}$ & 120 & 20 & 100 & 90 \\
\hline $5 v$ & & $\begin{array}{l}\mathrm{AcONa} 0.1 \mathrm{eq} \\
\mathrm{AcOH} 6.6 \mathrm{eq}\end{array}$ & 120 & 20 & 100 & 79 \\
\hline $5 w$ & & $\begin{array}{c}\text { piperidine } 0.1 \mathrm{eq} \\
\mathrm{AcOH} 0.1 \mathrm{eq}\end{array}$ & 150 & 20 & 200 & 64 \\
\hline $5 x$ & & $\begin{array}{l}\mathrm{AcONa} 0.1 \mathrm{eq} \\
\mathrm{AcOH} 6.6 \mathrm{eq}\end{array}$ & 120 & 20 & 100 & 98 \\
\hline
\end{tabular}

${ }^{a}$ Microwave irradiation (MWI) of the reaction mixture was realized in a glass tube sealed with a snap cap (closed vessel). ${ }^{b}$ Explorer ${ }^{\circledR}$ 24 (CEM $\mu$ Wave France) used as a microwave reactor (Power max.: $300 \mathrm{~W}$ ). ${ }^{c}$ Isolated yield after work up, crystallization, and washing using appropriate solvent.

Results given in Table 4 showed that, among these products $\mathbf{3}$, the molecules $\mathbf{3} \mathbf{j}-\mathbf{1}$ and $3 \mathbf{n}-\mathbf{t}$ were completely inactive on the four kinases, DYRK1A, CK1, CDK5/p25, and GSK3, for which $\mathrm{IC}_{50}$ values $>10 \mu \mathrm{M}$ were observed. Some interesting results were obtained for products $3 \mathbf{h}, \mathbf{i}, 3 \mathbf{m}$, and $3 \mathbf{u}, \mathbf{v}$ with micromolar $\mathrm{IC}_{50}$ values for DYRK1A. Among these compounds, the presence of the aminoacetic moiety on $\mathrm{N}-3$ position of $3 \mathbf{u}$ leads to enhancement of the inhibitory kinase activity for DYRK1A $\left(3 \mathbf{u}\right.$ : $\left.\mathrm{IC}_{50} 0.16 \mu \mathrm{M}\right)$. The most promising results were obtained with products $\mathbf{3 a}, \mathbf{3} \mathbf{c}$, and $\mathbf{3 e}-\mathbf{g}$ in this series, which exhibited selective, and sub-micromolar inhibitory activity toward DYRK1A $\left(0.090 \mu \mathrm{M}>\mathrm{IC}_{50}>0.028 \mu \mathrm{M}\right)$. The molecule $3 \mathrm{c}$ bearing a hydroxyl group at the $\mathrm{C}-4$ position of the exocyclic phenyl ring was strongly considered as the most interesting compound with an $\mathrm{IC}_{50}$ value of $0.028 \mu \mathrm{M}$. In compound $\mathbf{3} \mathbf{j}$, the presence of a supplementary hydroxyl group in the C-3 position of the phenyl ring completely decreases inhibition of kinase activity $\left(3 \mathbf{j}: \mathrm{IC}_{50}>10 \mu \mathrm{M}\right)$, which confirms that the presence of only one hydroxyl group on the phenyl ring of $3 \mathrm{c}$ seems to be crucial for an optimal inhibition activity. In product 3e, a small methoxy group was partially tolerated, but the DYRK1A inhibition activity decreases slightly (3c: $\left.\mathrm{IC}_{50} 0.064 \mu \mathrm{M}\right)$. The introduction of more bulky groups at the 5-ylidene position as 1,3benzodioxol-5-yl in $3 \mathbf{a}\left(\mathrm{IC}_{50} 0.070 \mu \mathrm{M}\right)$ or 2,3-dihydro-1,4-benzodioxin-5-yl in $3 \mathbf{f}$ (IC 50 $0.056 \mu \mathrm{M})$ or 2,3-dihydro-benzofuran-5-yl in $3 \mathrm{~g}\left(\mathrm{IC}_{50} 0.090 \mu \mathrm{M}\right)$ maintained partially the kinase inhibition activity. 
Table 4. Effects of the (5Z) 5-arylidene-2-thioxo-1,3-thiazolidin-4-one 3a-v intermediates on the catalytic activity of four purified protein kinases ${ }^{a}$.

\begin{tabular}{|c|c|c|c|c|}
\hline Compound & DYRK1A & CK1 & CDK5/p25 & GSK $3 \alpha / \beta$ \\
\hline $3 a$ & 0.070 & - & $>10$ & 8.5 \\
\hline $3 b$ & 1.4 & - & - & $>10$ \\
\hline $3 c$ & 0.064 & $\geq 10$ & 8 & 8 \\
\hline $3 d$ & $>10$ & - & - & - \\
\hline $3 e$ & 0.028 & $>10$ & $>10$ & $>10$ \\
\hline $3 f$ & 0.056 & - & - & $\leq 10$ \\
\hline $3 g$ & 0.090 & - & - & $\geq 10$ \\
\hline $3 \mathrm{~h}$ & 0.35 & - & - & 1.6 \\
\hline $3 \mathbf{i}$ & 0.7 & - & - & $>10$ \\
\hline $3 \mathbf{j}$ & $>10$ & - & - & $>10$ \\
\hline $3 k$ & $>10$ & - & $>10$ & $>10$ \\
\hline 31 & 15 & - & - & $>100$ \\
\hline $3 m$ & 6.5 & - & - & $>10$ \\
\hline $3 n$ & $>10$ & - & - & $>10$ \\
\hline 30 & $>10$ & - & - & $>10$ \\
\hline $3 p$ & $>10$ & - & - & $>10$ \\
\hline $3 q$ & $>10$ & - & - & $>10$ \\
\hline $3 r$ & $>10$ & - & - & $>10$ \\
\hline $3 s$ & $>10$ & - & - & $>10$ \\
\hline $3 t$ & $>10$ & - & - & $>10$ \\
\hline $3 \mathbf{u}$ & 0.16 & - & - & $>10$ \\
\hline $3 v$ & 0.70 & - & - & $>10$ \\
\hline Harmine $^{b}$ & 0.029 & 1.5 & $>10$ & $>10$ \\
\hline$(R)$-Roscovitine ${ }^{b}$ & 11.0 & 2.3 & 0.2 & 130 \\
\hline
\end{tabular}

${ }^{a}$ Compounds were tested at various concentrations on each kinase as described in Experimental Section. $\mathrm{IC}_{50}$ values, calculated from the dose-response curves, are reported in $\mu \mathrm{M}$. -, inactive at the highest concentration tested $(10 \mu \mathrm{M}) ;>10$, inhibitory, but $\mathrm{IC}_{50}>10 \mu \mathrm{M} .{ }^{b} \mathrm{IC}_{50}$ values; see refs. [39,40].

Concerning the library of the twenty-four (5Z) 2-amino-5-arylidene-1,3-thiazolidin$4(5 H)$-one $5 \mathbf{a}-\mathbf{x}$ derivatives, the results are given in Table 5 . The main part of their activity was focused on DYRK1A (and GSK3 $\alpha / \beta$ for some of them) for fourteen products in this second series $(\mathbf{5 a}, \mathbf{5 e}-\mathbf{g}, \mathbf{5 k}-\mathbf{m}, \mathbf{5 p}-\mathbf{r}$, and $\mathbf{5 u}-\mathbf{x})$, which exhibited inhibitory activity in the micromolar and sub-micromolar ranges $\left(2.3 \mu \mathrm{M}>\mathrm{IC}_{50}>0.12 \mu \mathrm{M}\right)$. For the three compounds $5 \mathbf{i}, \mathbf{5 n}$, and $5 \mathbf{o}$, we observed low nano-molar inhibition activity of DYRK1A ( $\mathrm{IC}_{50}$ values for $5 \mathbf{i}: 0.053 \mu \mathrm{M}, 5 \mathrm{n}: 0.070 \mu \mathrm{M}$, and $5 \mathbf{0}: 0.090 \mu \mathrm{M}$ ) with moderate selectivity because they are also able to inhibit GSK3 $\alpha / \beta$. It is interesting to note that these three compounds $\mathbf{5 i}, \mathbf{5 n}$, and $\mathbf{5 o}$ are, respectively, substituted with bulky groups at the 5-ylidene position (1,3-benzodioxol-5-yl or 2,3-dihydro-1,4-benzodioxin-5-yl) and piperidin-1-yl or thiomorpholin-1-yl moieties in the C-2 position of the 1,3-thiazolidin-4(5H)-one platform. Finally, introducing a pyridin-2-yl group in N-2 position of the molecule $5 s$ resulted in selective and sub-micromolar affinity for DYRK1A $\left(5 s\right.$ : IC I0 $\left._{50} 0.033 \mu \mathrm{M}\right)$. Replacement of the pyridin-2-yl group in N-2 position by a pyridin-4-yl at the same position in compound $5 \mathbf{t}$ resulted in a complete loss of kinase inhibitory activity on DYRK1A $\left(5 \mathbf{t}: \mathrm{IC}_{50}>10 \mu \mathrm{M}\right)$. Again, the replacement of the pyridin-2-yl or pyridin-4-yl moiety in N-2 position by a phenyl group, as example in molecule $5 \mathbf{r}$, maintained a moderate inhibition activity at a micromolar range $\left(5 \mathrm{r}\right.$ : $\left.\mathrm{IC}_{50} 0.61 \mu \mathrm{M}\right)$.

Comparison of all the results obtained in the two series showed the difficulties to define any role for the various substituents on the exocyclic phenyl ring (arylidene moiety in C-5 position), as well on the amino substituents in $\mathrm{N}-2$ position, in order to obtain sub-micromolar affinity for DYRK1A with good selectivity. However, it is interesting to note that the presence of hydroxyl group in para-position of the phenyl ring of 5-arylidene2-thioxo-1,3-thiazolidin-4-one derivative $3 \mathrm{c}$ is very important to access of a sub-micromolar inhibitory activity for DYRK1A. However, the presence of the bulky 1,3-benzodioxol-5$\mathrm{yl}$ group on the 5-arylidene moiety is not a crippling factor when it is associated with 
a thiomorpholin-1-yl substituent in N-2 position, with is the case for the compound $5 \mathbf{n}$ $\left(\mathrm{IC}_{50} 0.070 \mu \mathrm{M}\right)$.

Table 5. Effects of the (5Z) 2-amino-5-arylidene-1,3-thiazol-4(5H)-one derivatives 5a-x on the catalytic activity of four purified protein kinases ${ }^{a}$.

\begin{tabular}{|c|c|c|c|c|}
\hline Compound & DYRK1A & CK1 & CDK5/p25 & GSK $3 \alpha / \beta$ \\
\hline $5 a$ & 0.63 & - & - & 7.4 \\
\hline $5 b$ & $>10$ & - & - & - \\
\hline $5 c$ & - & - & - & - \\
\hline $5 d$ & $>10$ & - & - & - \\
\hline $5 e$ & 1.8 & - & - & $\leq 8.8$ \\
\hline $5 f$ & 2.3 & - & - & - \\
\hline $5 g$ & 0.4 & - & - & $\geq 10$ \\
\hline $5 \mathrm{~h}$ & - & - & - & - \\
\hline $5 i$ & 0.053 & - & - & 7.4 \\
\hline $5 \mathbf{j}$ & $\geq 10$ & - & - & - \\
\hline $5 k$ & $\overline{1} .6$ & - & - & - \\
\hline 51 & 1.8 & - & - & $>10$ \\
\hline $5 \mathrm{~m}$ & 0.6 & $>10$ & - & $\geq 10$ \\
\hline $5 n$ & 0.070 & $>10$ & - & 5.3 \\
\hline 50 & 0.090 & $\geq 10$ & - & 4.7 \\
\hline $5 p$ & 0.94 & $\geq 10$ & - & $>10$ \\
\hline $5 q$ & 0.17 & - & - & 3.7 \\
\hline $5 r$ & 0.61 & - & - & - \\
\hline $5 s$ & 0.033 & - & - & $\leq 10$ \\
\hline $5 t$ & $>10$ & - & - & $>10$ \\
\hline $5 u$ & 0.9 & - & - & $>10$ \\
\hline $5 v$ & 9.0 & $>10$ & $>10$ & $>10$ \\
\hline $5 w$ & 0.12 & - & - & - \\
\hline $5 x$ & 0.27 & - & - & - \\
\hline Harmine & 0.029 & 1.5 & $>10$ & $>10$ \\
\hline (R)-Roscovitine & 11 & 2.3 & 0.2 & 130 \\
\hline
\end{tabular}

${ }^{a}$ Compounds were tested at various concentrations on each kinase as described in Experimental Section. IC ${ }_{50}$ values, calculated from the dose-response curves, are reported in $\mu \mathrm{M}$. -, inactive at the highest concentration tested $(10 \mu \mathrm{M}) ;>10$, inhibitory, but $\mathrm{IC}_{50}>10 \mu \mathrm{M}$.

To evaluate the potency of selected compounds 3 and 5 for their in vitro inhibition of cell proliferation, we used a panel of 6 representative tumoral cell lines, namely Huh7 (differential hepatocellular carcinoma), $\mathrm{Caco} 2$ (differentiating colorectal adenocarcinoma), HCT (actively proliferating colorectal carcinoma), PC3 (prostate carcinoma), NCI-H2 (lung carcinoma), MDA-MB 231 (breast carcinoma), and diploid skin fibroblasts, as normal cell lines for control. Results of the in vitro antiproliferative data activity are reported in Table 6. The most active compound is clearly the (5Z)-5-(2,3-dihydro-benzofuran-5-ylmethylene)-2thioxo-1,3-thiazolidin-4-one $\mathbf{3 g}$, which exhibits antitumor activities in the Caco2 and HCT 116 cell lines with $\mathrm{IC}_{50}$ values lower than $10 \mu \mathrm{M}$ (Caco2: $\mathrm{IC}_{50} 8 \mu \mathrm{M}$ and HCT 116: $\mathrm{IC}_{50}$ $6 \mu \mathrm{M})$. Compound $3 \mathrm{~g}$ also presents a selective and sub-micromolar inhibitory activity on DYRK1A $\left(\mathrm{IC}_{50} 0.090 \mu \mathrm{M}\right)$. It is interesting to note that $3 \mathrm{c}$ is also moderately active in the HCT 116 cell line (IC $5012 \mu \mathrm{M}$ ) but showed a more efficient inhibitory activity for DYRK1A $\left(\mathrm{IC}_{50} 0.064 \mu \mathrm{M}\right)$. Compounds $3 \mathrm{c}$ and $3 \mathrm{~g}$ also did not exhibit the growth of normal fibroblasts $\left(\mathrm{IC}_{50}>25 \mu \mathrm{M}\right)$. In the selected (5Z) 2amino-5-arylidene-1,3-thiazol-4(5H)-one derivatives 5 , none of these compounds presented a significant activity against the six representative tumoral cell lines. 
Table 6. Effects of the (5Z) 2-amino-5-arylidene-1,3-thiazol-4(5H)-one derivatives $5 \mathbf{r}-\mathbf{x}^{a}$ and (5Z) 5-arylidene-2-thioxo-1,3thiazolidin-4-one $\mathbf{3 a}-\mathbf{c}, \mathbf{3 f}, \mathbf{g}$ derivatives ${ }^{b}$ on six representative tumoral cell lines.

\begin{tabular}{|c|c|c|c|c|c|c|c|}
\hline \multirow{2}{*}{ Compound } & \multicolumn{7}{|c|}{ Cell Lines $\mathrm{IC}_{50}(\mu \mathrm{M})$} \\
\hline & Huh7 D12 & Caco2 & MDA-MB231 & HCT116 & PC3 & NCI-H727 & Fibroblasts \\
\hline $5(r-x)$ & $>25$ & $>25$ & $>25$ & $>25$ & $>25$ & $>25$ & $>25$ \\
\hline $3 a$ & $>25$ & $>25$ & $>25$ & $>25$ & $>25$ & $>25$ & $>25$ \\
\hline $3 b$ & $>25$ & $>25$ & $>25$ & $>25$ & $>25$ & $>25$ & $>25$ \\
\hline $3 c$ & $>25$ & $>25$ & $>25$ & 12 & $>25$ & $>25$ & $>25$ \\
\hline $3 f$ & $>25$ & $>25$ & $>25$ & $>25$ & $>25$ & $>25$ & $>25$ \\
\hline $3 g$ & $>25$ & $>25$ & $>25$ & $>25$ & $>25$ & $>25$ & $>25$ \\
\hline Roscovitine & 10 & 8 & 15 & 6 & 20 & $>25$ & $>25$ \\
\hline DMSO & $>25$ & $>25$ & $>25$ & $>25$ & $>25$ & $>25$ & $>25$ \\
\hline
\end{tabular}

${ }^{a}$ The other derivatives $\mathbf{5 a - q}$ have not been tested, or some of them are not soluble in the conditions for the preparation of the biological test.

${ }^{b}$ The other derivatives $\mathbf{3 d}$, $\mathbf{e}$ and $\mathbf{3 h}-\mathbf{v}$ have not been tested, or some of them are not soluble in the conditions for the preparation of the biological test.

\section{Material and Methods}

\subsection{Chemistry-General Remarks}

Melting points were determined on a Kofler melting point apparatus and were uncorrected. ${ }^{1} \mathrm{H}$ NMR spectra were recorded on BRUKER AC $300 \mathrm{P}(300 \mathrm{MHz})$ spectrometer, ${ }^{13} \mathrm{C}$ NMR spectra on BRUKER AC 300 P (75 MHz) spectrometer. Chemical shifts are expressed in parts per million downfield from tetramethylsilane as an internal standard. Data are given in the following order: $\delta$ value, multiplicity (s, singlet; $\mathrm{d}$, doublet; $\mathrm{t}$, triplet; $\mathrm{q}$, quartet; $\mathrm{m}$, multiplet; br, broad), and number of protons, and coupling constants $J$ is given in Hertz. The mass spectra (HRMS) were taken, respectively, on a MS/MS ZABSpec Tof Micromass (EBE TOF geometry) at an ionizing potential of $8 \mathrm{eV}$ and on a VARIAN MAT 311 at an ionizing potential of $70 \mathrm{eV}$ in the "Centre Régional de Mesures Physiques de l'Ouest" (CRMPO, Rennes, France). Reactions under microwave irradiations were realized in the Synthewave ${ }^{\circledR} 402$ apparatus (Merck Eurolab, Div. Prolabo, France) or in the Explorer ${ }^{\circledR}$ 24 CEM microwave reactor (CEM France, Saclay, France), as well as in the Anton Paar Monowave $300^{\circledR}$ microwave reactor (Anton Paar France, Les Ulis, France). Microwave irradiation reactions were realized in open cylindrical quartz reactor $(\varnothing=1.8 \mathrm{~cm})$ with the Synthewave ${ }^{\circledR} 402$ apparatus or in borosilicate glass vials of $10 \mathrm{~mL}$ equipped with snap caps (at the end of the irradiation, cooling reaction was realized by compressed air) with the Explorer ${ }^{\circledR} 24$ or Monowave ${ }^{\circledR} 300$ reactors. The microwave instrument consists of a continuous focused microwave power output from 0 to 300W for the Synthewave ${ }^{\circledR} 402$ or the Explorer ${ }^{\circledR} 24$ CEM apparatus and from 0 to $800 \mathrm{~W}$ for the Anton Paar Monowave $300^{\circledR}$ apparatus. All the experiments in each microwave reactor were performed using the stirring option. The target temperature was reached with a ramp of 2-5 min, and the chosen microwave power stays constant to hold the mixture at this temperature. The reaction temperature is monitored using calibrated infrared sensor and the reaction time included the ramp period. The microwave irradiation parameters (power and temperature) were monitored by the ChemDriver software package for the Explorer ${ }^{\circledR} 24$ CEM apparatus and by the Monowave software package for the Anton Paar Monowave $300^{\circledR}$ reactor. Solvents were evaporated with a BUCHI rotary evaporator. All reagents and solvents were purchased from Acros (Geel, Belgium), Sigma-Aldrich Chimie (Saint-Quentin-Fallavier, France), and Fluka France and were used without further purification.

3.1.1. Standard Procedure for the Preparation of 5-Arylidene-2-thioxo-1,3-thiazolidin-4-one (3a-1) in the Synthewave ${ }^{\circledR} 402$ Microwave Reactor

In a cylindrical quartz reactor $(\varnothing=1.8 \mathrm{~cm})$, successively commercial rhodanine $1 \mathrm{a}$ ( 1 eq), aromatic aldehyde 2 ( 1 eq), and $n$-propylamine ( 2 eq) were placed. The reactor was then introduced into the Synthewave ${ }^{\circledR} 402$ Prolabo microwave cavity (power: $300 \mathrm{~W}$ ). The stirred mixture was irradiated at $80^{\circ} \mathrm{C}$ (after a ramp of $2 \mathrm{~min}$. from 20 to $80^{\circ} \mathrm{C}$ ) for $60 \mathrm{~min}$ (power level: $30 \%, 90 \mathrm{~W}$ ). After microwave dielectric heating, the crude reaction mixture 
was allowed to cooling down at room temperature, and ethanol $(20 \mathrm{~mL})$ was added in the cylindrical quartz reactor. The resulting insoluble product 3 was filtered, recrystallized in $\mathrm{EtOH}$, and dried under high vacuum $\left(10^{-2}\right.$ Torr $)$ for $1 \mathrm{~h}$.

(5Z)-5-(1,3-Benzodioxol-5-ylmethylene)-2-thioxo-1,3-thiazolidin-4-one (3a). According to the standard procedure, 3a was synthesized from commercial rhodanine 1 a (958 mg, $7.2 \mathrm{mmol})$, piperonaldehyde $2 \mathrm{a}(1.081 \mathrm{~g}, 7.2 \mathrm{mmol})$, and $n$-propylamine $(1.17 \mathrm{~mL}, 839 \mathrm{mg}, 14.2 \mathrm{mmol})$ in 79\% yield as light-yellow powder; $\mathrm{mp}=246-250{ }^{\circ} \mathrm{C} .{ }^{1} \mathrm{H}$ NMR $\left(\mathrm{DMSO}-d_{6}\right) \delta: 6.13(\mathrm{~s}, 2 \mathrm{H}$, $\left.\mathrm{OCH}_{2} \mathrm{O}\right) ; 7.11$ (d, 3H, J = 8.7 Hz, H-2, H-5, H-6, Ar); 7.54 (s, 1H, =CH); 13.74 (br s, 1H, NH). ${ }^{13} \mathrm{C}$ NMR (DMSO-d $\left.d_{6}\right) \delta: 102.1\left(\mathrm{OCH}_{2} \mathrm{O}\right) ; 109.2\left(\mathrm{C}-2^{\prime}\right) ; 109.4\left(\mathrm{C}-5^{\prime}\right) ; 122.8(\mathrm{C}=, \mathrm{C}-5) ; 126.6$ $\left(\mathrm{C}-6^{\prime}\right) ; 127.1(\mathrm{CH}=) ; 131.8\left(\mathrm{C}-7^{\prime}\right) ; 148.2\left(\mathrm{C}-4^{\prime}\right) ; 149.6\left(\mathrm{C}-3^{\prime}\right) ; 169.3$ (C=O, C-4); 195.3 (C=S, C-2). HRMS, $m / z$ : 264.9864 found (calculated for $\mathrm{C}_{11} \mathrm{H}_{7} \mathrm{NO}_{3} \mathrm{~S}_{2}, \mathrm{M}^{+}$. requires 264.9867).

(5Z)-5-(3-Hydroxy-4-methoxybenzylidene)-2-thioxo-1,3-thiazolidin-4-one (3b). According to the standard procedure, $\mathbf{3 b}$ was synthesized from commercial rhodanine $\mathbf{1 a}$ (958 mg, $7.2 \mathrm{mmol})$, 3-hydroxy-4-methoxybenzaldehyde $2 \mathrm{~d}$ (1.095 g, $7.2 \mathrm{mmol})$, and $n$-propylamine $(1.17 \mathrm{~mL}$, $839 \mathrm{mg}, 14.2 \mathrm{mmol})$ in $81 \%$ yield as light-yellow powder; $\mathrm{mp}=222-224{ }^{\circ} \mathrm{C} .{ }^{1} \mathrm{H}$ NMR $\left(\mathrm{DMSO}_{-} \mathrm{d}_{6}\right) \delta: 3.82\left(\mathrm{~s}, 3 \mathrm{H}, \mathrm{OCH}_{3}\right) ; 6.94(\mathrm{~d}, 1 \mathrm{H}, J=6 \mathrm{~Hz}, \mathrm{H}-6, \mathrm{Ar}) ; 7.04(\mathrm{~d}, 1 \mathrm{H}, J=7.9 \mathrm{~Hz}$, $\mathrm{H}-5, \mathrm{Ar}) ; 7.11$ (s, 1H, H-2, Ar); 7.53 (s, 1H, =CH); 10.06 (br s, 1H, OH); 13.65 (br s, 1H, $\mathrm{NH}) .{ }^{13} \mathrm{C}$ NMR (DMSO-d 6 ) $\delta: 56.0\left(\mathrm{OCH}_{3}\right) ; 114.7\left(\mathrm{C}-2^{\prime}\right) ; 116.7\left(\mathrm{C}-5^{\prime}\right) ; 121.5(\mathrm{C}=, \mathrm{C}-5) ; 124.8$ $\left(\mathrm{C}-6^{\prime}\right) ; 125.5\left({\left.\mathrm{C}-1^{\prime}\right)}_{1}\right.$; 133.1 (=CH); $148.5\left(\mathrm{C}-4^{\prime}\right) ; 150.4\left(\mathrm{C}-3^{\prime}\right) ; 169.8$ (C=O, C-4); 195.8 (C=S, C-2). HRMS, $m / z$ : 267.0023 found (calculated for $\mathrm{C}_{11} \mathrm{H}_{9} \mathrm{NO}_{3} \mathrm{~S}_{2}, \mathrm{M}^{+}$. requires 267.0024).

(5Z)-5-(4-Hydroxy-3-methoxybenzylidene)-2-thioxo-1,3-thiazolidin-4-one (3c). According to the standard procedure, 3c was synthesized from commercial rhodanine 1a (665 mg, $5 \mathrm{mmol})$, 4-hydroxy-3-methoxybenzaldehyde $2 \mathrm{e}(1.52 \mathrm{~g}, 10 \mathrm{mmol})$, and n-propylamine $(1.64 \mathrm{~mL}$, $1.18 \mathrm{~g}, 20 \mathrm{mmol}$ ) in 80\% yield as light-yellow powder; $\mathrm{mp}=220-222{ }^{\circ} \mathrm{C}$. ${ }^{1} \mathrm{H}$ NMR (DMSO$\left.d_{6}\right) \delta: 3.82\left(\mathrm{~s}, 3 \mathrm{H}, \mathrm{OCH}_{3}\right) ; 7.00(\mathrm{~d}, 1 \mathrm{H}, J=8.9 \mathrm{~Hz}, \mathrm{H}-6, \mathrm{Ar}) ; 7.07$ (d, 1H, J = 8.6 Hz, H-5, Ar); 7.13 (s, H-2, Ar); 7.48 (s, 1H, =CH); 9.57 (br s, $1 \mathrm{H}, \mathrm{OH}) ; 13.62$ (br s, $1 \mathrm{H}, \mathrm{NH}) .{ }^{13} \mathrm{C} \mathrm{NMR}$ $\left(\mathrm{DMSO}_{6}\right)$ $\delta: 56.1\left(\mathrm{OCH}_{3}\right) ; 112.9\left(\mathrm{C}-2^{\prime}\right) ; 116.5\left(\mathrm{C}-5^{\prime}\right) ; 122.4(\mathrm{C}=, \mathrm{C}-5) ; 124.8\left(\mathrm{C}-6^{\prime}\right) ; 126.1$

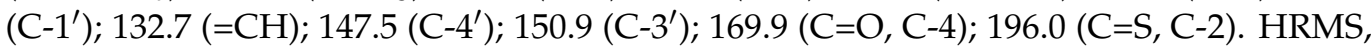
$m / z: 267.0022$ found (calculated for $\mathrm{C}_{11} \mathrm{H}_{9} \mathrm{NO}_{3} \mathrm{~S}_{2}, \mathrm{M}^{+\cdot}$ requires 267.0024).

(5Z)-5-(3,4-Dimethoxybenzylidene)-2-thioxo-1,3-thiazolidin-4-one (3d). According to the standard procedure, $\mathbf{3 d}$ was synthesized from commercial rhodanine $\mathbf{1 a}$ (958 mg, $7.2 \mathrm{mmol}$ ), 3,4-dimethoxybenzaldehyde $2 \mathrm{~h}(1.19 \mathrm{~g}, 7.2 \mathrm{mmol})$, and $n$-propylamine $(1.18 \mathrm{~mL}, 851 \mathrm{mg}$, $14.4 \mathrm{mmol}$ ) in $83 \%$ yield as light-yellow powder; $\mathrm{mp}=232-234{ }^{\circ} \mathrm{C} .{ }^{1} \mathrm{H}$ NMR $\left(\mathrm{DMSO}-d_{6}\right)$ $\delta: 3.74\left(\mathrm{~s}, 3 \mathrm{H}, \mathrm{OCH}_{3}\right) ; 3.81\left(\mathrm{~s}, 3 \mathrm{H}, \mathrm{OCH}_{3}\right) ; 7.14(\mathrm{~s}, 1 \mathrm{H}, \mathrm{H}-2, \mathrm{Ar}) ; 7.32(\mathrm{~d}, 1 \mathrm{H}, J=8.6 \mathrm{~Hz}, \mathrm{H}-5$, Ar); $7.44(\mathrm{~d}, 1 \mathrm{H}, J=6.3 \mathrm{~Hz}, \mathrm{H}-6, \mathrm{Ar}) ; 7.59$ (s, 1H, =CH); 13.72 (br s, $1 \mathrm{H}, \mathrm{NH}) .{ }^{13} \mathrm{C}$ NMR $\left(\mathrm{DMSO}_{6}\right) \delta$ : $57.0\left(\mathrm{OCH}_{3}\right) ; 57.1\left(\mathrm{OCH}_{3}\right) ; 112.4\left(\mathrm{C}-2^{\prime}\right) ; 112.7\left(\mathrm{C}-5^{\prime}\right) ; 123.6(\mathrm{C}=, \mathrm{C}-5) ; 124.8$

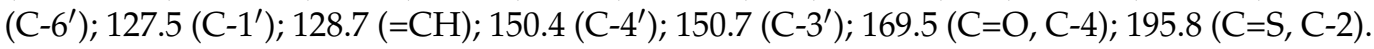
HRMS, $m / z$ : 281.0167 found (calculated for $\mathrm{C}_{12} \mathrm{H}_{11} \mathrm{NO}_{3} \mathrm{~S}_{2}, \mathrm{M}^{+\cdot}$ requires 281.0184).

(5Z)-5-(4-Hydroxybenzylidene)-2-thioxo-1,3-thiazolidin-4-one (3e). According to the standard procedure, $3 \mathbf{e}$ was synthesized from commercial rhodanine $1 \mathbf{1 a}(1.33 \mathrm{~g}, 10 \mathrm{mmol})$, 4-hydroxybenzaldehyde $2 \mathbf{i}(1.22 \mathrm{~g}, 10 \mathrm{mmol})$, and $n$-propylamine $(1.64 \mathrm{~mL}, 1.18 \mathrm{~g}, 20 \mathrm{mmol})$ in $80 \%$ yield as light-yellow powder; $\mathrm{mp}=240-242{ }^{\circ} \mathrm{C} .{ }^{1} \mathrm{H}$ NMR $\left(\mathrm{DMSO}-d_{6}\right) \delta: 6.91(\mathrm{~d}, 2 \mathrm{H}$, $J=8.6 \mathrm{~Hz}, \mathrm{H}-3, \mathrm{Ar}) ; 7.47$ (d, 2H, J = 8.6 Hz, H-2, Ar); 7.58 (S, 1H, =CH); 10.48 (br s, 1H, OH); 13.68 (br s, 1H, NH). ${ }^{13} \mathrm{C} \mathrm{NMR}\left(\mathrm{DMSO}_{6}\right) \delta: 116.7\left(\mathrm{C}-3^{\prime}\right) ; 123.9\left(\mathrm{C}-2^{\prime}\right) ; 123.8$ (C=, C-5); 129.1 $\left(\mathrm{C}-1^{\prime}\right) ; 130.7$ (=CH); $159.9\left(\mathrm{C}-4^{\prime}\right) ; 169.7$ (C=O, C-4); 195.7 (C=S, C-2). HRMS, m/z: 236.9918 found (calculated for $\mathrm{C}_{10} \mathrm{H}_{7} \mathrm{NO}_{2} \mathrm{~S}_{2}, \mathrm{M}^{+}$. requires 236.99182 ).

(5Z)-5-(2,3-Dihydro-1,4-benzodioxin-6-ylmethylene)-2-thioxo-1,3-thiazolidin-4-one (3f). According to the standard procedure, $\mathbf{3} \mathbf{f}$ was synthesized from commercial rhodanine $\mathbf{1 a}(958 \mathrm{mg}$, $7.2 \mathrm{mmol}), 2$,3-dihydro-1,4-benzodioxin-6-carboxaldehyde 2c (1.18 g, $7.2 \mathrm{mmol})$, and $n$ propylamine $(1.18 \mathrm{~mL}, 851 \mathrm{mg}, 14.4 \mathrm{mmol})$ in $89 \%$ yield as light-yellow powder; $\mathrm{mp}=250-252{ }^{\circ} \mathrm{C} .{ }^{1} \mathrm{H}$ NMR $\left(\mathrm{DMSO}_{6}\right) \delta: 4.29\left(\mathrm{t}, 2 \mathrm{H}, \mathrm{OCH}_{2} \mathrm{CH}_{2} \mathrm{O}\right) ; 4.30\left(\mathrm{t}, 2 \mathrm{H}, \mathrm{OCH}_{2} \mathrm{CH}_{2} \mathrm{O}\right)$; 7.02 (d, 1H, J = 8.1 Hz, H-5, Ar); 7.08 (s, 1H, H-2, Ar); 7.10 (d, 1H, J = 8.2 Hz; H-6, Ar); $7.53(\mathrm{~s}, 1 \mathrm{H},=\mathrm{CH}) ; 13.76($ br s, $1 \mathrm{H}, \mathrm{NH}) .{ }^{13} \mathrm{C} \mathrm{NMR}\left(\mathrm{DMSO}-d_{6}\right) \delta: 63.8\left(\mathrm{OCH}_{2} \mathrm{CH}_{2} \mathrm{O}\right) ; 64.4$ 
$\left(\mathrm{OCH}_{2} \mathrm{CH}_{2} \mathrm{O}\right) ; 118.6\left(\mathrm{C}-5^{\prime}\right) ; 119.7\left(\mathrm{C}-2^{\prime}\right) ; 123.5(=\mathrm{CH}) ; 124.7\left(\mathrm{C}-6^{\prime}\right) ; 126.7\left(\mathrm{C}-1^{\prime}\right) ; 132.1(\mathrm{C}=$, C-5); 144.2 (C-4'); 146.5 (C-3'); 170.0 (C=O, C-4); 195.9 (C=S, C-2). HRMS, m/z: 279.0016 found (calculated for $\mathrm{C}_{12} \mathrm{H}_{9} \mathrm{NO}_{3} \mathrm{~S}_{2}, \mathrm{M}^{+}$. requires 279.0024).

(5Z)-5-(2,3-Dihydro-benzofuran-5-ylmethylene)-2-thioxo-1,3-thiazolidin-4-one (3g). According to the standard procedure, $3 \mathrm{~g}$ was synthesized from commercial rhodanine $1 \mathrm{a}(1.357 \mathrm{~g}$, $10.2 \mathrm{mmol}), 2$,3-dihydro-1-benzofuran-5-carbaldehyde $2 \mathbf{b}(1.067 \mathrm{mg}, 7.2 \mathrm{mmol})$, and $n$ propylamine (1.67 mL, $1.205 \mathrm{~g}, 20.4 \mathrm{mmol})$ in $79 \%$ yield as light-yellow powder; $\mathrm{mp}=250-252{ }^{\circ} \mathrm{C} .{ }^{1} \mathrm{H}$ NMR $\left(\mathrm{DMSO}-d_{6}\right) \delta: 4.02\left(\mathrm{t}, 2 \mathrm{H}, J=6.8 \mathrm{~Hz} ; \mathrm{CH}_{2} \mathrm{CH}_{2} \mathrm{O}\right) ; 6.02(\mathrm{t}$, $\left.2 \mathrm{H}, J=6.9 \mathrm{~Hz} ; \mathrm{CH}_{2} \mathrm{C}_{2} \mathrm{O}\right) ; 6.84(\mathrm{~d}, 1 \mathrm{H}, J=8 \mathrm{~Hz}, \mathrm{H}-3, \mathrm{Ar}) ; 7.12(\mathrm{dd}, 1 \mathrm{H}, J=8,1.5 \mathrm{~Hz}$, $\mathrm{H}-2, \mathrm{Ar}) ; 7.37$ (d, $1 \mathrm{H}, J=1.4 \mathrm{~Hz}, \mathrm{H}-6, \mathrm{Ar}) ; 8.16(\mathrm{~s}, 1 \mathrm{H},=\mathrm{CH}) ; 13.66$ (br s, $1 \mathrm{H}, \mathrm{NH}) .{ }^{13} \mathrm{C}$ NMR (DMSO- $\left.d_{6}\right) \delta: 29.2\left(\mathrm{CH}_{2} \mathrm{CH}_{2} \mathrm{O}\right) ; 71.7\left(\mathrm{CH}_{2} \mathrm{CH}_{2} \mathrm{O}\right) ; 107.0\left(\mathrm{C}-5^{\prime}\right) ; 108.4\left(\mathrm{C}-2^{\prime}\right) ; 123.5$ $(=\mathrm{CH}) ; 124.7\left(\mathrm{C}-6^{\prime}\right) ; 126.7\left(\mathrm{C}-1^{\prime}\right) ; 132.1(\mathrm{C}=, \mathrm{C}-5) ; 144.2\left(\mathrm{C}-4^{\prime}\right) ; 148.6\left(\mathrm{C}-3^{\prime}\right) ; 170.0(\mathrm{C}=\mathrm{O}$, C-4); 195.9 (C=S, C-2). HRMS, $m / z: 263.0063$ found (calculated for $\mathrm{C}_{12} \mathrm{H}_{9} \mathrm{NO}_{2} \mathrm{~S}_{2}, \mathrm{M}^{+}$. requires 263.0075).

(5Z)-5-\{[6-(1,3-Benzodioxol-5-yl)pyridin-2-yl]methylene\}-2-thioxo-1,3-thiazolidin-4-one (3h). According to the standard procedure, $3 \mathrm{~h}$ was synthesized from commercial rhodanine $\mathbf{1 a}(18 \mathrm{mg}$, $0.134 \mathrm{mmol}), 6-(1,3-$-benzodioxol-5-yl)-2-pyridinecarbaldehyde $2 \mathrm{k}(30 \mathrm{mg}, 0.134 \mathrm{mmol})$, and $n$-propylamine (22 $\mathrm{mL}, 15.8 \mathrm{mg}, 0.268 \mathrm{mmol}$ ) in $79 \%$ yield as light-yellow powder; $\mathrm{mp}=246-250{ }^{\circ} \mathrm{C} .{ }^{1} \mathrm{H}$ NMR $\left(\mathrm{DMSO}_{6}\right) \delta: 6.05\left(\mathrm{~s}, 2 \mathrm{H}, \mathrm{OCH}_{2} \mathrm{O}\right) ; 6.94\left(\mathrm{~d}, 1 \mathrm{H}, J=8 \mathrm{~Hz}, \mathrm{H}-3^{\prime}\right)$; $7.55\left(\mathrm{dd}, 1 \mathrm{H}, J=8,1.5 \mathrm{~Hz}, \mathrm{H}-2^{\prime}\right) ; 7.59(\mathrm{~d}, 1 \mathrm{H}, J=8 \mathrm{~Hz}, \mathrm{H}-3) ; 7.66(\mathrm{dd}, 1 \mathrm{H}, J=8,1.5 \mathrm{~Hz}, \mathrm{H}-5)$; $7.77(\mathrm{t}, 1 \mathrm{H}, J=8 \mathrm{~Hz}, \mathrm{H}-4) ; 7.93\left(\mathrm{dd}, 1 \mathrm{H}, J=1.4 \mathrm{~Hz}, \mathrm{H}-6^{\prime}\right) ; 8.46(\mathrm{~s}, 1 \mathrm{H},=\mathrm{CH}) ; 12.46(\mathrm{br} \mathrm{s}, 1 \mathrm{H}$, $\mathrm{NH}) .{ }^{13} \mathrm{C}$ NMR (DMSO-d 6 ) $\delta: 101.8\left(\mathrm{OCH}_{2} \mathrm{O}\right) ; 107.0\left(\mathrm{C}-5^{\prime \prime}\right) ; 107.5\left(\mathrm{C}-6^{\prime}\right) ; 108.4\left(\mathrm{C}-2^{\prime \prime}\right) ; 114.0$ $\left(\mathrm{C}-4^{\prime}\right) ; 116.0(\mathrm{C}=, \mathrm{C}-5) ; 118.0\left(\mathrm{C}-5^{\prime \prime}\right) ; 124.5\left(\mathrm{C}-6^{\prime \prime}\right) ; 13 ., 6\left(\mathrm{C}-1^{\prime \prime}\right) ; 131.9$ (=CH); $132.1\left(\mathrm{C}-3^{\prime \prime}\right) ; 132.4$ (C-2'); 148.6 (C-3"); 150.0 (C-4"); 169.9 (C=O, C-4); 192.4 (C=S, C-2). HRMS, $m / z: 342.0131$ found (calculated for $\mathrm{C}_{16} \mathrm{H}_{10} \mathrm{~N}_{2} \mathrm{O}_{3} \mathrm{~S}_{2}, \mathrm{M}^{+\cdot}$ requires 342.0133).

(5Z)-5-[(7-Bromo-1,3-benzodioxol-5-yl)methylene]-2-thioxo-1,3-thiazolidin-4-one (3i). According to the standard procedure, $3 \mathbf{i}$ was synthesized from commercial rhodanine $1 \mathbf{a}(1.31 \mathrm{~g}$, $9.8 \mathrm{mmol}), 7$-bromo-1,3-benzodioxole-5-carbaldehyde 21 ( $2.24 \mathrm{~g}, 9.8 \mathrm{mmol})$, and $n$-propyla mine $(1.6 \mathrm{~mL}, 1.15 \mathrm{~g}, 19.6 \mathrm{mmol})$ in $70 \%$ yield as light-yellow powder; $\mathrm{mp}>260{ }^{\circ} \mathrm{C} .{ }^{1} \mathrm{H}$ NMR (DMSO- $\left.d_{6}\right) \delta: 6.18\left(\mathrm{~s}, 2 \mathrm{H}, \mathrm{OCH}_{2} \mathrm{O}\right) ; 6.37(\mathrm{~s}, 1 \mathrm{H}, \mathrm{H}-6) ; 7.39(\mathrm{~s}, 1 \mathrm{H}, \mathrm{H}-2) ; 7.88(\mathrm{~s}, 1 \mathrm{H}$, $=\mathrm{CH}) ; 12.10(\mathrm{br} \mathrm{s}, 1 \mathrm{H}, \mathrm{NH}) .{ }^{13} \mathrm{C}$ NMR $\left(\mathrm{DMSO}-d_{6}\right) \delta: 100.7(\mathrm{C}-\mathrm{Br}) ; 102.7\left(\mathrm{OCH}_{2} \mathrm{O}\right) ; 109.4$ $\left(\mathrm{C}-2^{\prime}\right) ; 110.7(=\mathrm{CH}) ; 127.7\left(\mathrm{C}-6^{\prime}\right) ; 128.1\left(\mathrm{C}-1^{\prime}\right) ; 128.7(\mathrm{C}=, \mathrm{C}-5) ; 146.8\left(\mathrm{C}-4^{\prime}\right) ; 148.7\left(\mathrm{C}-3^{\prime}\right) ; 166.4$ $(\mathrm{C}=\mathrm{O}, \mathrm{C}-4) ; 192.6(\mathrm{C}=\mathrm{S}, \mathrm{C}-2)$. HRMS, $m / z: 342.8923$ found (calculated for $\mathrm{C}_{11} \mathrm{H}_{16}{ }^{79} \mathrm{BrNO}_{3} \mathrm{~S}_{2}$, $\mathrm{M}^{+\cdot}$ requires 342.8972$)$.

(5Z)-5-(3,4-Dihydroxybenzylidene)-2-thioxo-1,3-thiazolidin-4-one (3j). According to the standard procedure, $3 \mathbf{j}$ was synthesized from commercial rhodanine $\mathbf{1 a}(1.385 \mathrm{~g}, 10.4 \mathrm{mmol})$, 3,4-dihydroxybenzaldehyde $2 \mathrm{f}(1.44 \mathrm{~g}, 10.4 \mathrm{mmol})$, and $n$-propylamine $(1.7 \mathrm{~mL}, 1.23 \mathrm{~g}$, $20.8 \mathrm{mmol}$ ) in $79 \%$ yield as light-yellow powder; $\mathrm{mp}=210-212{ }^{\circ} \mathrm{C} .{ }^{1} \mathrm{H}$ NMR (DMSO- $d_{6}$ ) $\delta: 6.82(\mathrm{~s}, 1 \mathrm{H}, \mathrm{H}-2) ; 6.89$ (d, 1H, J = 8.6 Hz, H-6); 7.05 (d, 1H, J = 8.2 Hz, H-5); 7.47 (s, 1H, $=\mathrm{CH}) ; 9.54(\mathrm{br} \mathrm{s}, 1 \mathrm{H}, \mathrm{OH}) ; 9.96(\mathrm{br} \mathrm{s}, 1 \mathrm{H}, \mathrm{OH}) ; 13.66(\mathrm{br} \mathrm{s}, 1 \mathrm{H}, \mathrm{NH}) .{ }^{13} \mathrm{C}$ NMR $\left(\mathrm{DMSO}-d_{6}\right)$

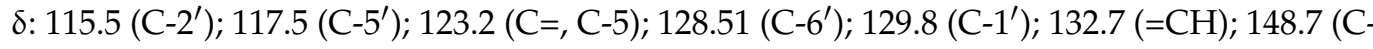
$\left.4^{\prime}\right) ; 149.4\left(\mathrm{C}-3^{\prime}\right) ; 169.6(\mathrm{C}=\mathrm{O}, \mathrm{C}-4) ; 195.8(\mathrm{C}=\mathrm{S}, \mathrm{C}-2)$. HRMS, $m / z: 252.9862$ found (calculated for $\mathrm{C}_{10} \mathrm{H}_{7} \mathrm{NO}_{3} \mathrm{~S}_{2}, \mathrm{M}^{+\cdot}$ requires 252.9867).

(5Z)-5-(3,5-Dihydroxybenzylidene)-2-thioxo-1,3-thiazolidin-4-one (3k). According to the standard procedure, 3k was synthesized from commercial rhodanine $1 \mathbf{a}(1.385 \mathrm{~g}, 10.4 \mathrm{mmol})$, 3,5-dihydroxybenzaldehyde $2 \mathrm{n}(1.44 \mathrm{~g}, 10.4 \mathrm{mmol})$, and $n$-propylamine $(1.7 \mathrm{~mL}, 1.23 \mathrm{~g}$, $20.8 \mathrm{mmol}$ ) in $79 \%$ yield as light-yellow powder; $\mathrm{mp}=230-232{ }^{\circ} \mathrm{C} .{ }^{1} \mathrm{H}$ NMR (DMSO- $d_{6}$ ) $\delta: 6.62(\mathrm{~s}, 1 \mathrm{H}, \mathrm{H}-3) ; 6.65(\mathrm{~d}, 1 \mathrm{H}, J=8.7 \mathrm{~Hz}, \mathrm{H}-5) ; 7.46(\mathrm{~d}, 1 \mathrm{H}, J=5.8 \mathrm{~Hz}, \mathrm{H}-6) ; 7.94(\mathrm{~s}, 1 \mathrm{H}$, $=\mathrm{CH}) ; 10.23(\mathrm{br} \mathrm{s}, 1 \mathrm{H}, \mathrm{OH}) ; 10.54(\mathrm{br} \mathrm{s}, 1 \mathrm{H}, \mathrm{OH}) ; 13.72(\mathrm{br} \mathrm{s}, 1 \mathrm{H}, \mathrm{NH}) .{ }^{13} \mathrm{C}$ NMR $\left(\mathrm{DMSO}-d_{6}\right)$ ঠ: $104.9\left(\mathrm{C}-3^{\prime}\right) ; 110.1\left(\mathrm{C}-5^{\prime}\right) ; 114.1\left(\mathrm{C}-6^{\prime}\right) ; 122.4(\mathrm{C}=, \mathrm{C}-5) ; 130.5\left(\mathrm{C}-1^{\prime}\right) ; 130.8(=\mathrm{CH}) ; 159.8(\mathrm{C}-$ 2'); $161.1\left(\mathrm{C}-4^{\prime}\right) ; 169.9(\mathrm{C}=\mathrm{O}, \mathrm{C}-4)$; 196.1 (C=S, C-2). HRMS, $m / z: 252.9859$ found (calculated for $\mathrm{C}_{10} \mathrm{H}_{7} \mathrm{NO}_{3} \mathrm{~S}_{2}, \mathrm{M}^{++}$requires 252.9867). 
(5Z)-5-(1-Benzofuran-2-ylmethylene)-2-thioxo-1,3-thiazolidin-4-one (31). According to the standard procedure, 31 was synthesized from commercial rhodanine 1a $(1.33 \mathrm{~g}, 10 \mathrm{mmol})$, 1-benzofuran-2-carbaldehyde $2 \mathrm{~m}(1.52 \mathrm{~g}, 10.4 \mathrm{mmol})$, and $n$-propylamine $(1.64 \mathrm{~mL}, 1.18 \mathrm{~g}$, $20 \mathrm{mmol}$ ) in $62 \%$ yield as light-yellow powder; $\mathrm{mp}=246-250{ }^{\circ} \mathrm{C}$. ${ }^{1} \mathrm{H}$ NMR $\left(\mathrm{DMSO}-d_{6}\right)$ $\delta: 6.98$ (s, 1H, C-3); 7.11-7.28 (m, 2H, H-5, H-6); 7.47 (d, 1H, J = $7.7 \mathrm{~Hz}, \mathrm{H}-7) ; 7.83(\mathrm{~d}$, $1 \mathrm{H}, J=7.5 \mathrm{~Hz}, \mathrm{H}-4) ; 8.51$ (s, 1H, H-2); 8.98 (s, $1 \mathrm{H},=\mathrm{CH}) ; 12.10$ (br s, $1 \mathrm{H}, \mathrm{NH}) .{ }^{13} \mathrm{C} \mathrm{NMR}$ $\left(\mathrm{DMSO}-d_{6}\right) \delta: 107.2(=\mathrm{CH}) ; 108.8\left(\mathrm{C}-3^{\prime}\right) ; 112.6\left(\mathrm{C}-7^{\prime}\right) ; 118.6\left(\mathrm{C}-4^{\prime}\right) ; 121.2\left(\mathrm{C}-5^{\prime}\right) ; 122.1(\mathrm{C}=$,

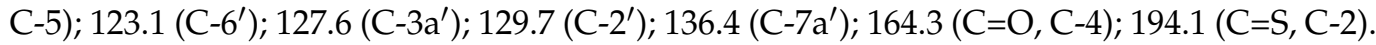
HRMS, $m / z$ : 260.9842 found (calculated for $\mathrm{C}_{12} \mathrm{H}_{7} \mathrm{NO}_{2} \mathrm{~S}_{2}, \mathrm{M}^{+}$. requires 260.9918).

7-Bromo-1,3-benzodioxole-5-carbaldehyde (21). In a $25 \mathrm{~mL}$ round-bottomed flask provided with a magnetic stirrer and condenser, a mixture of commercial 3-bromo-4,5-dihydroxybenz aldehyde (217 mg, $1 \mathrm{mmol}$ ), potassium fluoride (529 mg, $9.1 \mathrm{mmol}, 9.1 \mathrm{eq})$, and dibromomethane $(70 \mathrm{~mL}, 173 \mathrm{mg}, 1 \mathrm{mmol})$ in $3 \mathrm{~mL}$ of dimethylformamide was stirred vigorously under a stream of nitrogen for $4 \mathrm{~h}$ at $140^{\circ} \mathrm{C}$ in an oil bath. After cooling down to room temperature, $3 \mathrm{~mL}$ of deionized water was added in one portion to the crude reaction mixture. The resulting solution was submitted to extraction with $\mathrm{Et}_{2} \mathrm{O}(3 \times 5 \mathrm{~mL})$, and, after decantation, the organic layer was dried over $\mathrm{MgSO}_{4}$. After filtration, the solvent of the filtrate was eliminated in a rotary evaporator under reduced pressure; then, the crude residue was dried under high vacuum $\left(10^{-2}\right.$ Torr $)$ at $25^{\circ} \mathrm{C}$ for $2 \mathrm{~h}$. The desired 7-bromo-1,3-benzodioxole-5-carbaldehyde 21 was obtained as a light-yellow powder in $51 \%$ yield (117 $\mathrm{mg}$ ) and was sufficiently pure to be used further without purification; $\mathrm{mp}=123-125{ }^{\circ} \mathrm{C} .{ }^{1} \mathrm{H}$ NMR $\left(\mathrm{DMSO}_{6}\right) \delta: 6.17\left(\mathrm{~s}, 2 \mathrm{H}, \mathrm{OCH}_{2} \mathrm{O}\right) ; 7.28(\mathrm{~d}, 1 \mathrm{H}, J=1.4 \mathrm{~Hz}, \mathrm{H}-2$, $\mathrm{Ar}) ; 7.55(\mathrm{~d}, 1 \mathrm{H}, \mathrm{J}=1.3 \mathrm{~Hz}, \mathrm{H}-6)$; 9.78 (s, 1H, CHO). ${ }^{13} \mathrm{C}$ NMR (DMSO-d 6 ) $\delta: 100.9$ (C-Br); $102.6\left(\mathrm{OCH}_{2} \mathrm{O}\right) ; 106.2$ (C-2); 131.0 (C-6); 132.8 (C-1); 148.9 (C-4); 151.2 (C-3); 189.1 (C=O). HRMS, $m / z$ : 227.9426 found (calculated for $\mathrm{C}_{8} \mathrm{H}_{5} \mathrm{O}_{3}{ }^{79} \mathrm{Br}, \mathrm{M}^{+}$. requires 227.9422).

3.1.2. Standard Procedure for the Preparation of 5-Arylidene-2-thioxo-1,3-thiazolidin-4-one $(3 \mathbf{m}, \mathbf{n})$ in the Monowave ${ }^{\circledR} 300$ Microwave Reactor

In a $10 \mathrm{~mL}$ glass tube were placed successively commercial rhodanine $\mathbf{1 a}(1 \mathrm{eq})$, aromatic aldehyde 2o,p (1.1-1.2 eq), sodium acetate $(26.4 \mathrm{mg}, 0.31 \mathrm{mmol}, 0.1 \mathrm{eq})$, and glacial acetic acid (1.2 eq). The glass tube was sealed with a snap cap and placed in the Monowave $300^{\circledR}$ Anton-Paar microwave cavity (power $=850 \mathrm{~W}$ ). The mixture was irradiated at $140{ }^{\circ} \mathrm{C}$ for 20-30 min under vigorous magnetic stirring. After microwave dielectric heating, the crude reaction mixture was allowed to cool down at room temperature. To this crude mixture, $4 \mathrm{~mL}$ of deionized water was added, and the resulting suspension was submitted to ultrasound in a Branson 1510 apparatus at $25{ }^{\circ} \mathrm{C}$ for $30 \mathrm{~min}$. Then, the desired compound 3 was collected by filtration, and the crude solid was washed with $5 \mathrm{~mL}$ of deionized water and dried under high vacuum $\left(10^{-2}\right.$ Torr $)$ at $25^{\circ} \mathrm{C}$ for $2 \mathrm{~h}$.

(5Z)-5-(Chroman-6-yl)methylene-2-thioxo-1,3-thiazolidin-4-one (3m). According to the standard procedure, $3 \mathrm{~m}$ was synthesized after a reaction time of $20 \mathrm{~min}$ from commercial rhodanine 1 a (200 mg, $1.5 \mathrm{mmol})$, 6-chromanecarbaldehyde 20 (292 mg, $1.8 \mathrm{mmol})$, sodium acetate $(147 \mathrm{mg}, 1.8 \mathrm{mmol})$, and glacial acetic acid $(0.6 \mathrm{~mL}, 108 \mathrm{mg}, 1.8 \mathrm{mmol})$ in $93 \%$ yield as light-yellow powder; mp > $260{ }^{\circ} \mathrm{C}$. ${ }^{1} \mathrm{H}$ NMR $\left(\right.$ DMSO- $\left._{6}\right) \delta: 1.92\left(\mathrm{~m}, 2 \mathrm{H}, \mathrm{CH}_{2}\right) ; 2.77(\mathrm{t}, 2 \mathrm{H}$, $\left.J=6.3 \mathrm{~Hz}, \mathrm{CH}_{2}\right) ; 4.19\left(\mathrm{~m}, 2 \mathrm{H}, \mathrm{CH}_{2}\right) ; 6.83(\mathrm{~d}, 1 \mathrm{H}, J=8.4 \mathrm{~Hz}, \mathrm{Ar}) ; 7.27(\mathrm{~m}, 2 \mathrm{H}, \mathrm{Ar}) ; 7.47$ (s, 1H, CH=); 12.06 (br s, 1H, NH). $\left.{ }^{13} \mathrm{C} \mathrm{NMR} \mathrm{(DMSO-d} 6\right) \delta: 21.3\left(\mathrm{CH}_{2}\right) ; 24.1\left(\mathrm{CH}_{2}\right) ; 66.6$ $\left(\mathrm{CH}_{2}\right) ; 117.5$ (=CH); 121.9 (Ar); 123.6 (C=, C-5); 124.9 (Ar); 130.2 (Ar); 131.9 (Ar); 132.8 (Ar); 157.0 (Ar); 169.7 (C=O, C-4); 195.6 (C=S, C-2). HRMS, $m / z: 300.0129$ found (calculated for $\mathrm{C}_{15} \mathrm{H}_{11} \mathrm{NO}_{2} \mathrm{NaS}_{2},[\mathrm{M}+\mathrm{Na}]^{+\cdot}$ requires 300.0129).

(5Z)-5-(3,4-Dihydro-2H-1,5-benzodioxepine-7-yl)methylene-2-thioxo-1,3-thiazolidin-4-one (3n). According to the standard procedure, $3 \mathrm{n}$ was synthesized after a reaction time of $20 \mathrm{~min}$ from commercial rhodanine $1 \mathrm{a}$ (200 mg, $1.5 \mathrm{mmol})$, 3,4-dihydro-2H-1,5-benzodioxepine-7carbaldehyde $2 \mathrm{p}$ (321 mg, $1.8 \mathrm{mmol})$, sodium acetate $(147 \mathrm{mg}, 1.8 \mathrm{mmol})$, and glacial acetic acid $(0.6 \mathrm{~mL}, 108 \mathrm{mg}, 1.8 \mathrm{mmol})$ in $94 \%$ yield as light-yellow powder; $\mathrm{mp}=220-222{ }^{\circ} \mathrm{C} .{ }^{1} \mathrm{H}$ NMR (DMSO- $\left.d_{6}\right) \delta: 2.13\left(\mathrm{~m}, 2 \mathrm{H}, \mathrm{CH}_{2}\right) ; 4.20\left(\mathrm{~m}, 4 \mathrm{H}, 2 \mathrm{CH}_{2}\right) ; 7.05(\mathrm{~m}, 1 \mathrm{H}, \mathrm{Ar}) ; 7.15(\mathrm{~m}, 2 \mathrm{H}$, 
Ar); $7.50(\mathrm{~s}, 1 \mathrm{H}, \mathrm{CH}=) ; 13.68$ (br s, $1 \mathrm{H}, \mathrm{NH}) .{ }^{13} \mathrm{C} \mathrm{NMR}\left(\mathrm{DMSO}-d_{6}\right) \delta: 30.7\left(\mathrm{CH}_{2}\right) ; 70.4\left(\mathrm{CH}_{2}\right)$; $70.5\left(\mathrm{CH}_{2}\right) ; 122.4(\mathrm{CH}=)$ 123.7 (Ar); $123.8(\mathrm{C}=, \mathrm{C}-5) ; 125.9(\mathrm{Ar}) ; 128.1(\mathrm{Ar}) ; 131.0(\mathrm{Ar}) ; 150.9$ (Ar); 153.0 (Ar); 169.3 (C=O, C-4); 195.4 (C=S, C-2). HRMS, $m / z: 316.0079$ found (calculated for $\mathrm{C}_{18} \mathrm{H}_{13} \mathrm{NO}_{2} \mathrm{NaS}_{2}$, $[\mathrm{M}+\mathrm{Na}]^{+}$. requires 316.0078).

(5Z)-3-Amino-5-benzo[1,3]dioxol-5-ylmethylene-2-thioxo-thiazolidin-4-one (3o). In a $25 \mathrm{~mL}$ round-bottomed flask provided with a magnetic stirrer and condenser, a mixture of commercial 3-amino rhodanine $\mathbf{1 d}(197 \mathrm{mg}, 1.33 \mathrm{mmol})$, piperonaldehyde $\mathbf{2 a}(200 \mathrm{~g}, 1.33 \mathrm{mmol})$, triethylamine $(19 \mathrm{~mL}, 13 \mathrm{mg}, 0.13 \mathrm{mmol}, 0.1 \mathrm{eq})$, and glacial acetic acid $(8 \mu \mathrm{L}, 8 \mathrm{mg}$, $0.13 \mathrm{mmol}, 0.1 \mathrm{eq}$ ) in $4.3 \mathrm{~mL}$ of ethyl acetate was stirred vigorously under a stream of argon for $3.5 \mathrm{~h}$ at $85^{\circ} \mathrm{C}$ in an oil bath. After cooling down to room temperature, the insoluble product of the orange reaction mixture was filtered, washed with absolute ethanol $(2 \times 3 \mathrm{~mL})$, and was dried under high vacuum $\left(10^{-2}\right.$ Torr $)$ for $1 \mathrm{~h}$. The desired 3-amino-5-benzo[1,3]dioxol-5-ylmethylene-2-thioxo-thiazolidin-4-one 30 was obtained as a light-yellow powder in $26 \%$ yield $(97 \mathrm{mg}) ; \mathrm{mp}=224-226{ }^{\circ} \mathrm{C} .{ }^{1} \mathrm{H}$ NMR $\left(\right.$ DMSO- $\left.d_{6}\right) \delta: 5.92$ $\left(\mathrm{s}, 2 \mathrm{H}, \mathrm{NH}_{2}\right) ; 6.15$ (s, 2H, H-1); 7.12 (d, 1H, J = 8.1Hz, H-7); 7.19-7.25 (m, 2H, H-3, H-4); 7.79 $(\mathrm{s}, 1 \mathrm{H}, \mathrm{H}-5) ; 12.71$ (br s, $1 \mathrm{H}, \mathrm{NH}) .{ }^{13} \mathrm{C}$ NMR (DMSO-d 6 ) $8: 102.1\left(\mathrm{C}-1^{\prime}\right) ; 109.3\left(\mathrm{C}-4^{\prime}\right) ; 109.6$ $\left(\mathrm{C}-3^{\prime}\right) ; 117.5(\mathrm{C}=, \mathrm{C}-5) ; 127.0\left(\mathrm{C}-6^{\prime}\right) ; 127.2\left(\mathrm{C}-5^{\prime}\right) ; 133.5(\mathrm{CH}=) ; 148.3\left(\mathrm{C}-2^{\prime}\right) ; 149.9\left(\mathrm{C}-2^{\prime}\right) ; 163.7$ $(\mathrm{C}=\mathrm{O}, \mathrm{C}-4) ; 187.1$ ( $\mathrm{C}=\mathrm{S}, \mathrm{C}-2)$. HRMS, $m / z: 302.9872$ found (calculated for $\mathrm{C}_{11} \mathrm{H}_{8} \mathrm{~N}_{2} \mathrm{O}_{3} \mathrm{NaS}_{2}$, $[\mathrm{M}+\mathrm{Na}]^{+\cdot}$ requires 302.9874$)$.

3.1.3. Standard Procedure for the Preparation of 5-Arylidene-2-thioxo-1,3-thiazolidin-4-one $(3 \mathbf{p}, \mathbf{q})$ and $(3 \mathbf{s}, \mathbf{t})$ in the Explorer ${ }^{\circledR} 24$ Microwave Reactor

In a $10 \mathrm{~mL}$ glass tube were placed successively the 3- $\mathrm{N}$-amino rhodanine derivative 1 (1 eq), piperonaldehyde $\mathbf{2 a}(1 \mathrm{eq})$, piperidine ( $0.1 \mathrm{eq})$ or sodium acetate $(0.1 \mathrm{eq})$, and glacial acetic acid (0.1-6.6 eq). The glass tube was placed in the Explorer ${ }^{\circledR} 24$ CEM microwave cavity (power $=300 \mathrm{~W}$ ). The mixture was irradiated at 120 or $150{ }^{\circ} \mathrm{C}$ (with a power of 100 or $200 \mathrm{~W}$ ) for $20 \mathrm{~min}$ under vigorous magnetic stirring. After microwave dielectric heating, the insoluble compound 3 was separated from the crude reaction mixture by filtration. To the collected crude compound 3, absolute ethanol or deionized water was added, and the resulting suspension was stirred vigorously under magnetic stirring for $18 \mathrm{~h}$. The desired compound 3 was collected by filtration and was dried under high vacuum $\left(10^{-2}\right.$ Torr $)$ at $25{ }^{\circ} \mathrm{C}$ for $1 \mathrm{~h}$.

(5Z)-N-(5-Benzo[1,3]dioxol-5-ylmethylene-4-oxo-2-thioxo-thiazolidin-3-yl)-benzamide (3p). According to the standard procedure, $3 \mathbf{p}$ was synthesized at $150{ }^{\circ} \mathrm{C}$ with a power of $200 \mathrm{~W}$ from $N$-(4-oxo-2-thioxo-thiazolidin-3-yl)-benzamide $1 \mathrm{ff}(222 \mathrm{mg}, 1 \mathrm{mmol})$, piperonaldehyde 2a (150 mg, $1 \mathrm{mmol})$, piperidine $(10 \mu \mathrm{L}, 9 \mathrm{mg}, 0.1 \mathrm{mmol}, 0.1 \mathrm{eq})$, and glacial acetic acid $(6 \mu \mathrm{L}, 6 \mathrm{mg}, 0.1 \mathrm{mmol}, 0.1 \mathrm{eq})$ in $27 \%$ yield as light-yellow powder; $\mathrm{mp}=182-184{ }^{\circ} \mathrm{C} .{ }^{1} \mathrm{H}$ NMR (DMSO- $\left.d_{6}\right) \delta: 6.64(\mathrm{~s}, 2 \mathrm{H}, \mathrm{H}-1) ; 7.56(\mathrm{~d}, J=8.1 \mathrm{~Hz}, 1 \mathrm{H}, \mathrm{Ar}) ; 7.66(\mathrm{~d}, J=1.7 \mathrm{~Hz}, 1 \mathrm{H}$, Ar); $7.77(\mathrm{dd}, J=1.3,8.2 \mathrm{~Hz}, 1 \mathrm{H}, \mathrm{Ar}) ; 8.03(\mathrm{~m}, 2 \mathrm{H}, \mathrm{Ar}) ; 8.29(\mathrm{~s}, 1 \mathrm{H}, \mathrm{CH}=) ; 8.50(\mathrm{~m}, 1 \mathrm{H}, \mathrm{Ar})$; $8.53(\mathrm{~m}, 1 \mathrm{H}, \mathrm{Ar}) ; 12.03$ (br s, $\left.1 \mathrm{H}, \mathrm{H}-6^{\prime}\right) .{ }^{13} \mathrm{C}$ NMR $\left(\mathrm{DMSO}_{-} d_{6}\right) \delta: 102.3\left(\mathrm{OCH}_{2} \mathrm{O}\right) ; 109.4(\mathrm{Ar}) ;$ 109.80 (Ar); $116.4(\mathrm{C}=$, C-5); $126.9(\mathrm{C}=6) ; 127.6(\mathrm{Ar}) ; 127.8(\mathrm{Ar}) ; 128.8(\mathrm{Ar}) ; 132.9(\mathrm{Ar}) ; 135.2$ $(\mathrm{CH}=) ; 148.4\left(\mathrm{C}_{\text {ipso }}, \mathrm{C}_{\text {ortho }}, \mathrm{Ar}\right) ; 150.3\left(\mathrm{C}-2^{\prime}\right) ; 163.4(\mathrm{C}=\mathrm{O}) ; 164.5(\mathrm{C}=\mathrm{O}, \mathrm{C}-4) ; 190.3(\mathrm{C}=\mathrm{S}, \mathrm{C}-2)$. HRMS, $m / z$ : 385.0307 found (calculated for $\mathrm{C}_{18} \mathrm{H}_{13} \mathrm{~N}_{2} \mathrm{O}_{4} \mathrm{~S}_{2}$, $[\mathrm{M}+\mathrm{H}]^{+}$. requires 385.0317).

(5Z)-N-(5-Benzo[1,3]dioxol-5-ylmethylene-4-oxo-2-thioxo-thiazolidin-3-yl)-2-phenyl-acetamide (3q). According to the standard procedure, $\mathbf{3 q}$ was synthesized at $120{ }^{\circ} \mathrm{C}$ with a power of $100 \mathrm{~W}$ from $\mathrm{N}$-(4-oxo-2-thioxo-thiazolidin-3-yl)-2-phenyl-acetamide $1 \mathrm{~h}(50 \mathrm{mg}, 0.19 \mathrm{mmol})$, piperonaldehyde $2 \mathrm{a}(28 \mathrm{mg}, 0.19 \mathrm{mmol})$, sodium acetate $(15 \mathrm{mg}, 0.19 \mathrm{mmol}, 0.1 \mathrm{eq})$, and glacial acetic acid $(70 \mu \mathrm{L}, 74 \mathrm{mg}, 1.24 \mathrm{mmol}, 6.6 \mathrm{eq})$ in $98 \%$ yield as light-yellow powder; $\mathrm{mp}=216-218{ }^{\circ} \mathrm{C} .{ }^{1} \mathrm{H}$ NMR $\left(\mathrm{DMSO}-d_{6}\right) \delta: 3.71\left(\mathrm{~s}, 2 \mathrm{H}, \mathrm{CH}_{2} \mathrm{Ph}\right) ; 6.16\left(\mathrm{~s}, 2 \mathrm{H}, \mathrm{OCH}_{2} \mathrm{O}\right) ; 7.13$ $(\mathrm{d}, 1 \mathrm{H}, J=8.1 \mathrm{~Hz}, \mathrm{Ar}) ; 7.21(\mathrm{~m}, 1 \mathrm{H}, \mathrm{Ar}) ; 7.25(\mathrm{~m}, 1 \mathrm{H}, \mathrm{Ar}) ; 7.28(\mathrm{~m}, 1 \mathrm{H}, \mathrm{Ar}) ; 7.32-7.34(\mathrm{~m}$, $4 \mathrm{H}, \mathrm{Ar}) ; 7.84(\mathrm{~s}, 1 \mathrm{H}, \mathrm{CH}=) ; 11.44(\mathrm{br} \mathrm{s}, 1 \mathrm{H}, \mathrm{NH}) .{ }^{13} \mathrm{C}$ NMR $\left(\mathrm{DMSO}-d_{6}\right) \delta: 39.5\left(\mathrm{CH}_{2}\right) ; 102.3$ $\left(\mathrm{OCH}_{2} \mathrm{O}\right) ; 109.4(\mathrm{Ar}) ; 109.7(\mathrm{Ar}) ; 116.6(\mathrm{C}=, \mathrm{C}-5) ; 126.7(\mathrm{Ar}) ; 126.9\left(\mathrm{C}_{i p s o}, \mathrm{Ar}\right) ; 127.4(\mathrm{Ar}) ; 128.3$ (Ar); 129.1 (Ar); $134.6\left(\mathrm{C}_{i p s o}, \mathrm{Ar}\right) ; 134.9(\mathrm{Ar}) ; 148.4\left(\mathrm{C}_{\mathrm{Ar}} \mathrm{O}\right) ; 150.2\left(\mathrm{C}_{\mathrm{Ar}}-\mathrm{O}\right) ; 163.2(\mathrm{C}=\mathrm{O}) ; 168.6$ 
(C=O, C-4); 190.2 (C=S, C-2). HRMS, m/z: 421.0294 found (calculated for $\mathrm{C}_{19} \mathrm{H}_{14} \mathrm{~N}_{2} \mathrm{O}_{4} \mathrm{NaS}_{2}$, $[\mathrm{M}+\mathrm{Na}]^{+}$. requires 421.0293).

(5Z)-5-Benzo[1,3]dioxol-5-ylmethylene-3-[2-(4-methoxy-phenyl)-2-oxo-ethyl]-2-thioxo-thiazo lidin4-one (3s). According to the standard procedure, $3 \mathrm{~s}$ was synthesized at $120{ }^{\circ} \mathrm{C}$ with a power of $100 \mathrm{~W}$ from 4-methoxy- $\mathrm{N}$-(4-oxo-2-thioxo-thiazolidin-3-yl)-benzamide $1 \mathrm{~g}$ ( $50 \mathrm{mg}$, $0.18 \mathrm{mmol})$, piperonaldehyde $2 \mathrm{a}(27 \mathrm{mg}, 0.18 \mathrm{mmol})$, sodium acetate $(15 \mathrm{mg}, 0.18 \mathrm{mmol}$, $0.1 \mathrm{eq})$, and glacial acetic acid ( $70 \mu \mathrm{L}, 70 \mathrm{mg}, 1.17 \mathrm{mmol}, 6.6 \mathrm{eq})$ in $83 \%$ yield $(61 \mathrm{mg})$ as light-yellow powder; $\mathrm{mp}=226-228{ }^{\circ} \mathrm{C} .{ }^{1} \mathrm{H}$ NMR $\left(\mathrm{DMSO}-d_{6}\right) \delta: 3.85(\mathrm{~s}, 3 \mathrm{H}, \mathrm{MeO}) ; 6.18$ $\left(\mathrm{s}, 2 \mathrm{H}, \mathrm{OCH}_{2} \mathrm{O}\right) ; 7.11(\mathrm{~m}, 2 \mathrm{H}, \mathrm{Ar}) ; 7.15(\mathrm{~d}, 1 \mathrm{H}, J=8.2 \mathrm{~Hz}, \mathrm{Ar}) ; 7.26(\mathrm{~d}, 1 \mathrm{H}, J=1.7 \mathrm{~Hz}, \mathrm{Ar})$; $7.31(\mathrm{dd}, 1 \mathrm{H}, J=1.5,1.6,8.4 \mathrm{~Hz}, \mathrm{Ar}) ; 7.90(\mathrm{~s}, 1 \mathrm{H}, \mathrm{CH}=) ; 7.93(\mathrm{~m}, 1 \mathrm{H}, \mathrm{Ar}) ; 7.96(\mathrm{~m}, 1 \mathrm{H}, \mathrm{Ar})$; $11.61(\mathrm{~s}, 1 \mathrm{H}, \mathrm{Ar}) .{ }^{13} \mathrm{C}$ NMR (DMSO- $\left.d_{6}\right) \delta$ : $55.5\left(\mathrm{CH}_{3} \mathrm{O}\right) ; 102.3\left(\mathrm{OCH}_{2} \mathrm{O}\right) ; 109.4(\mathrm{Ar}) ; 109.8$ (Ar); 114.0 (Ar); 116.5 (C=, C-5); 122.8 (C Cipso $_{1}$ Ar); 126.9 (C $\left.C_{i p s o}, \mathrm{Ar}\right) ; 127.6(\mathrm{Ar}) ; 129.9$ (Ar); $135.1(\mathrm{CH}=) ; 148.4\left(\mathrm{O}-\mathrm{C}_{\mathrm{Ar}}\right) ; 150.3\left(\mathrm{O}-\mathrm{C}_{\mathrm{Ar}}\right) ; 162.8\left(\mathrm{C}_{i p s o}, \mathrm{Ar}\right) ; 163.5(\mathrm{C}=\mathrm{O}) ; 163.9(\mathrm{C}=\mathrm{O}, \mathrm{C}-4)$; 190.5 (C=S, C-2). HRMS, $m / z: 437.0237$ found (calculated for $\mathrm{C}_{19} \mathrm{H}_{14} \mathrm{~N}_{2} \mathrm{O}_{5} \mathrm{NaS}_{2},[\mathrm{M}+\mathrm{Na}]^{+}$. requires 437.0242$)$.

(5Z)-N-(5-Benzo[1,3]dioxol-5-ylmethylene-4-oxo-2-thioxo-thiazolidin-3-yl)-benzenesulfonam ide (3t). According to the standard procedure, $3 \mathbf{t}$ was synthesized at $150{ }^{\circ} \mathrm{C}$ with a power of $200 \mathrm{~W}$ from $\mathrm{N}$-(4-oxo-2-thioxo-thiazolidin-3-yl)-benzenesulfonamide $1 \mathrm{e}$ ( $100 \mathrm{mg}, 0.35 \mathrm{mmol})$, piperonaldehyde $2 \mathrm{a}(52 \mathrm{mg}, 0.35 \mathrm{mmol})$, piperidine $(3 \mu \mathrm{L}, 3 \mathrm{mg}, 0.034 \mathrm{mmol}, 0.1 \mathrm{eq})$, and glacial acetic acid $(2 \mu \mathrm{L}, 2 \mathrm{mg}, 0.034 \mathrm{mmol}, 0.1 \mathrm{eq})$ in $64 \%$ yield $(94 \mathrm{mg})$ as light-yellow powder; $\mathrm{mp}=214-216{ }^{\circ} \mathrm{C} .{ }^{1} \mathrm{H}$ NMR $\left(\mathrm{DMSO}-d_{6}\right) \delta: 6.16\left(\mathrm{~s}, 2 \mathrm{H}, \mathrm{OCH}_{2} \mathrm{O}\right) ; 7.12(\mathrm{~d}, 1 \mathrm{H}$, $J=8.1 \mathrm{~Hz}, \mathrm{Ar}) ; 7.19(\mathrm{~d}, 1 \mathrm{H}, J=1.6 \mathrm{~Hz}, \mathrm{Ar}) ; 7.24(\mathrm{dd}, 1 \mathrm{H}, J=1.7,8.2 \mathrm{~Hz}, \mathrm{Ar}) ; 7.59(\mathrm{~m}$, $2 \mathrm{H}, \mathrm{Ar}) ; 7.69(\mathrm{~m}, 1 \mathrm{H}, \mathrm{Ar}) ; 7.79(\mathrm{~s}, 1 \mathrm{H}, \mathrm{CH}=) ; 7.86(\mathrm{~m}, 2 \mathrm{H}, \mathrm{Ar}) ; 11.57$ (br s, $1 \mathrm{H}, \mathrm{NH}) .{ }^{13} \mathrm{C}$ NMR (DMSO-d 6 ) $\delta: 102.3\left(\mathrm{OCH}_{2} \mathrm{O}\right) ; 109.4(\mathrm{Ar}) ; 109.7$ (Ar); 115.9 (C=, C-5); $126.8\left(\mathrm{C}_{\text {ipso }}, \mathrm{Ar}\right)$; 127.3 (Ar); $127.5(\mathrm{Ar}) ; 129.1(\mathrm{Ar}) ; 133.5(\mathrm{Ar}) ; 134.9(\mathrm{CH}=) ; 140.7\left(\mathrm{C}_{i p s o}, \mathrm{Ar}\right) ; 148.3\left(\mathrm{O}-\mathrm{C}_{\mathrm{Ar}}\right)$; $150.2\left(\mathrm{O}-\mathrm{C}_{\mathrm{Ar}}\right) ; 163.4(\mathrm{C}=\mathrm{O}, \mathrm{C}-4) ; 189.6$ (C=S, C-2). HRMS, $m / z$ : 442.9785 found (calculated for $\mathrm{C}_{17} \mathrm{H}_{12} \mathrm{~N}_{2} \mathrm{O}_{5} \mathrm{NaS}_{3}$, [M+Na] ${ }^{+}$. requires 442.9806) and 301.9780 found (calculated for $\mathrm{C}_{11} \mathrm{H}_{7} \mathrm{~N}_{2} \mathrm{O}_{3} \mathrm{NaS}_{2}$, [M-SO $\left.\mathrm{Ph}+\mathrm{Na}\right]^{++}$. requires 301.9796).

3.1.4. Standard Procedure for the Preparation of 5-Arylidene-2-thioxo-1,3-thiazolidin-4-one $(3 \mathbf{r})$ and $(\mathbf{3 u}, \mathbf{v})$ in the Monowave ${ }^{\circledR} 300$ Microwave Reactor

In a $10 \mathrm{~mL}$ glass tube, the $3-\mathrm{N}$-amino rhodanine derivative $\mathbf{1}$ ( 1 eq), piperonaldehyde $2 \mathbf{a}(1 \mathrm{eq})$, piperidine ( $0.1 \mathrm{eq})$ or sodium acetate $(0.1 \mathrm{eq})$, and glacial acetic acid (0.1-6.6 eq) were successively placed. The glass tube was placed in the Monowave ${ }^{\circledR} 300$ Anton Paar microwave cavity (power $=850 \mathrm{~W}$ ). The mixture was irradiated at 120 or $150{ }^{\circ} \mathrm{C}$ for $20 \mathrm{~min}$ under vigorous magnetic stirring. After microwave dielectric heating, the reaction was allowed to cool down to room temperature. To this crude mixture, $2.5 \mathrm{~mL}$ of deionized water was added, and the resulting suspension was submitted to ultrasound in a Branson 1510 apparatus at $25^{\circ} \mathrm{C}$ for $30 \mathrm{~min}$. Then, the desired insoluble compound $\mathbf{3}$ was collected by filtration, and $2 \mathrm{~mL}$ of absolute ethanol was added to the collected compound 3 . The resulting suspension was stirred vigorously under magnetic stirring for $18 \mathrm{~h}$. The desired compound 3 was finally collected by filtration and was dried under high vacuum $\left(10^{-2}\right.$ Torr $)$ at $25^{\circ} \mathrm{C}$ for $1 \mathrm{~h}$.

(5Z)-N-(5-Benzo[1,3]dioxol-5-ylmethylene-4-oxo-2-thioxo-thiazolidin-3-yl)-3-phenyl-propiona mide (3r). According to the standard procedure, $3 \mathbf{r}$ was synthesized at $120^{\circ} \mathrm{C}$ from $\mathrm{N}$-(4-oxo-2thioxo-thiazolidin-3-yl)-3-phenyl-propionamide $1 \mathbf{i}(50 \mathrm{mg}, 0.18 \mathrm{mmol})$, piperonaldehyde $2 \mathbf{a}$ $(27 \mathrm{mg}, 0.18 \mathrm{mmol})$, sodium acetate $(15 \mathrm{mg}, 0.18 \mathrm{mmol}, 0.1 \mathrm{eq})$, and glacial acetic acid $(68 \mu \mathrm{L}$, $396 \mathrm{mg}, 6.6 \mathrm{mmol}, 6.6 \mathrm{eq})$ in $68 \%$ yield $(50 \mathrm{mg})$ as light-yellow powder; $\mathrm{mp}=226-228{ }^{\circ} \mathrm{C}$. ${ }^{1} \mathrm{H}$ NMR (DMSO- $\left.d_{6}\right) \delta: 2.65\left(\mathrm{~m}, 2 \mathrm{H}, \mathrm{CH}_{2} \mathrm{CO}\right) ; 2.91\left(\mathrm{~m}, 2 \mathrm{H}, \mathrm{CH}_{2} \mathrm{Ph}\right) ; 6.16\left(\mathrm{~s}, 2 \mathrm{H}, \mathrm{OCH}_{2} \mathrm{O}\right)$; 7.12-7.32 (m, 8H, Ar); 7.85 (s, 1H, CH=); $11.23(\mathrm{br} \mathrm{s}, 1 \mathrm{H}, \mathrm{NH}) .{ }^{13} \mathrm{C}$ NMR (DMSO- $\left.d_{6}\right) \delta: 30.4$ $\left(\mathrm{CH}_{2} \mathrm{Ar}\right) ; 34.5\left(\mathrm{CH}_{2} \mathrm{CO}\right) ; 102.3\left(\mathrm{OCH}_{2} \mathrm{O}\right) ; 109.4(\mathrm{Ar}) ; 109.8(\mathrm{Ar}) ; 116.7(\mathrm{C}=, \mathrm{C}-5) ; 126.1(\mathrm{Ar}) ;$ $126.9\left(\mathrm{C}_{i p s o}, \mathrm{Ar}\right) ; 127.4(\mathrm{Ar}) ; 128.3-128.4(\mathrm{Ar}) ; 134.8(\mathrm{CH}=) ; 140.5\left(\mathrm{C}_{i p s o}, \mathrm{Ar}\right) ; 148.4\left(\mathrm{O}-\mathrm{C}_{\mathrm{Ar}}\right)$; $150.2\left(\mathrm{O}-\mathrm{C}_{\mathrm{Ar}}\right) ; 163.3(\mathrm{C}=\mathrm{O}) ; 170.0(\mathrm{C}=\mathrm{O}, \mathrm{C}-4) ; 190.2$ (C=S, C-2). HRMS, $m / z: 435.0447$ found (calculated for $\mathrm{C}_{20} \mathrm{H}_{16} \mathrm{~N}_{2} \mathrm{O}_{4} \mathrm{NaS}_{2}$, [M+Na] $]^{+}$requires 435.0449). 
(5Z)-(5-Benzo[1,3]dioxol-5-ylmethylene-4-oxo-2-thioxo-thiazolidin-3-yl)-acetic acid (3u). According to the standard procedure, $3 \mathbf{u}$ was synthesized at $120{ }^{\circ} \mathrm{C}$ from 2-(4-oxo-2-thioxothiazolidin-3-yl)acetic acid $\mathbf{1 b}(255 \mathrm{mg}, 1.33 \mathrm{mmol})$, piperonaldehyde $\mathbf{2 a}(200 \mathrm{mg}, 1.33 \mathrm{mmol})$, piperidine $(13 \mu \mathrm{L}, 11 \mathrm{mg}, 0.13 \mathrm{mmol}, 0.1 \mathrm{eq})$, and glacial acetic acid $(8 \mu \mathrm{L}, 7.8 \mathrm{mg}, 0.13 \mathrm{mmol}$, $0.1 \mathrm{eq}$ ) in $72 \%$ yield $(308 \mathrm{mg})$ as light-yellow powder; $\mathrm{mp}>250{ }^{\circ} \mathrm{C} .{ }^{1} \mathrm{H} \mathrm{NMR}\left(\mathrm{DMSO}-d_{6}\right)$ $\delta: 4.81\left(\mathrm{~s}, 2 \mathrm{H}, \mathrm{CH}_{2} \mathrm{COH}\right) ; 6.26\left(\mathrm{~s}, 2 \mathrm{H}, \mathrm{OCH}_{2} \mathrm{O}\right) ; 7.23(\mathrm{~d}, 1 \mathrm{H}, \mathrm{J}=8.1 \mathrm{~Hz}, \mathrm{Ar}) ; 7.31-7.35(\mathrm{~m}$, 2H, Ar); 7.92 (s, 1H, CH=); 12.37 (br s, $1 \mathrm{H}, \mathrm{OH}) .{ }^{13} \mathrm{C} \mathrm{NMR}\left(\mathrm{DMSO}-d_{6}\right) \delta: 45.5\left(\mathrm{CH}_{2} \mathrm{CO}_{2} \mathrm{H}\right)$; $102.0\left(\mathrm{OCH}_{2} \mathrm{O}\right) ; 109.1$ (Ar); 109.4 (Ar); 118.9 (C=, C-5); 126.7 (C $\left.\mathrm{C}_{i p s o}, \mathrm{Ar}\right) ; 127.0$ (Ar); 133.9 $(\mathrm{CH}=) ; 148.1\left(\mathrm{O}-\mathrm{C}_{\mathrm{Ar}}\right) ; 149.9\left(\mathrm{O}-\mathrm{C}_{\mathrm{Ar}}\right) ; 166.1(\mathrm{C}=\mathrm{O}) ; 167.1$ (C=O, C-4); 192.7 (C=S, C-2). HRMS, $m / z: 322.9922$ found (calculated for $\mathrm{C}_{13} \mathrm{H}_{9} \mathrm{NO}_{5} \mathrm{~S}_{2},[\mathrm{M}]^{+\cdot}$ requires 322.9922) and 305.9897 found (calculated for $\mathrm{C}_{13} \mathrm{H}_{8} \mathrm{NO}_{4} \mathrm{~S}_{2},[\mathrm{M}-\mathrm{OH}]^{+}$requires 305.9895).

(5Z)-3-(5-Benzo[1,3]dioxol-5-ylmethylene-4-oxo-2-thioxo-thiazolidin-3-yl)-propionic acid (3v). According to the standard procedure, $3 \mathbf{v}$ was synthesized at $150^{\circ} \mathrm{C}$ from 3-(4-oxo-2-thioxothiazolidin-3-yl)-propionic acid 1c $(50 \mathrm{mg}, 0.24 \mathrm{mmol})$, piperonaldehyde $2 \mathrm{a}$ (37 $\mathrm{mg}$, $0.24 \mathrm{mmol})$, piperidine $(2 \mu \mathrm{L}, 2 \mathrm{mg}, 0.024 \mathrm{mmol}, 0.1 \mathrm{eq})$, and glacial acetic acid $(1.4 \mu \mathrm{L}$, $1.4 \mathrm{mg}, 0.024 \mathrm{mmol}, 0.1 \mathrm{eq})$ in $62 \%$ yield $(50 \mathrm{mg})$ as light-yellow powder; $\mathrm{mp}=218-220^{\circ} \mathrm{C}$. ${ }^{1} \mathrm{H}$ NMR $\left(\mathrm{DMSO}-d_{6}\right) \delta: 2.58\left(\mathrm{~m}, 2 \mathrm{H}, \mathrm{CH}_{2} \mathrm{CO}_{2} \mathrm{H}\right) ; 4.21\left(\mathrm{t}, 2 \mathrm{H}, \mathrm{J}=6.9 \mathrm{~Hz}, \mathrm{NCH}_{2}\right) ; 6.15(\mathrm{~s}$, $2 \mathrm{H}, \mathrm{OCH}_{2} \mathrm{O}$ ); 7.10-7.24 (m, 3H, Ar); 7.75 (br s, 1H, CH=); 11.95 (br s, 1H, OH). ${ }^{13} \mathrm{C} \mathrm{NMR}$ $\left(\mathrm{DMSO}-d_{6}\right) \delta: 31.0\left(\mathrm{CH}_{2} \mathrm{CO}_{2} \mathrm{H}\right) ; 102.2\left(\mathrm{OCH}_{2} \mathrm{O}\right) ; 109.3-109.6(\mathrm{Ar}) ; 119.7\left(\mathrm{C}_{i p s o}, \mathrm{Ar}\right) ; 126.8$ (Ar); $127.2(\mathrm{C}=, \mathrm{C}-5) ; 133.2(\mathrm{CH}=) ; 148.3\left(\mathrm{O}-\mathrm{C}_{\mathrm{Ar}}\right) ; 149.9\left(\mathrm{O}-\mathrm{C}_{\mathrm{Ar}}\right) ; 166.7(\mathrm{C}=\mathrm{O}) ; 171.8(\mathrm{C}=\mathrm{O}$, C-4); 193.0 (C=S, C-2). HRMS, $m / z$ : 336.0005 found (calculated for $\mathrm{C}_{14} \mathrm{H}_{10} \mathrm{NO}_{5} \mathrm{~S}_{2},[\mathrm{M}]^{+}$. requires 336.0004$)$.

3.1.5. Standard Procedure for the Preparation of $(5 Z)$

2-Amino-5-arylidene-1,3-thiazol-4(5H)-4-one (5a-q) by Sulphur-Nitrogen Displacement in the Synthewave ${ }^{\circledR} 402$ Microwave Reactor

In a cylindrical quartz reactor $(\varnothing=1.8 \mathrm{~cm})$, the (5Z)-5-arylidene-2-thioxo-1,3-thiazolid in-4-one 3 (0.5 mmol, $1 \mathrm{eq})$, and the secondary cyclic amine 4 (1.5 mmol, $3 \mathrm{eq}$ ) were successively placed. The reactor was then introduced into the Synthewave ${ }^{\circledR} 402$ Prolabo microwave cavity (power $=300 \mathrm{~W}$ ). The stirred mixture was irradiated (after a ramp of $3 \mathrm{~min}$ from 20 to the appropriate reaction temperature) at $80-120{ }^{\circ} \mathrm{C}$ (power: $80-150 \mathrm{~W}$ ) for 20-120 min. After microwave dielectric heating, the crude reaction mixture was allowed to cooling down at room temperature, and ethanol $(20 \mathrm{~mL})$ was added in the cylindrical quartz reactor. The resulting insoluble product 3 was filtered and recrystallized in absolute EtOH and then dried under high vacuum $\left(10^{-2}\right.$ Torr $)$ for $1 \mathrm{~h}$.

(5Z)-5-(1,3-Benzodioxol-5-ylmethylene)-2-(morpholin-1-yl)-1,3-thiazol-4(5H)-one (5a). According to the standard procedure, 5a was synthesized at $80{ }^{\circ} \mathrm{C}$ (power: $80 \mathrm{~W}$ ) after a reaction time of 20 min from (5Z)-5-(1,3-benzodioxol-5-ylmethylene)-2-thioxo-1,3-thiazolidin-4-one $3 \mathbf{a}(132 \mathrm{mg}, 0.5 \mathrm{mmol})$ and commercial morpholine $4 \mathrm{a}(131 \mu \mathrm{L}, 131 \mathrm{mg}, 1.5 \mathrm{mmol})$ in $96 \%$ yield $(153 \mathrm{mg})$ as light-yellow powder; $\mathrm{mp}=250-252{ }^{\circ} \mathrm{C} .{ }^{1} \mathrm{H}$ NMR $\left(\mathrm{DMSO}-d_{6}\right) \delta: 3.63(\mathrm{~m}$, $\left.4 \mathrm{H}, \mathrm{CH}_{2} \mathrm{NCH}_{2}\right) ; 3.90\left(\mathrm{~m}, 4 \mathrm{H}, \mathrm{CH}_{2} \mathrm{OCH}_{2}\right) ; 6.10\left(\mathrm{~s}, 2 \mathrm{H}, \mathrm{OCH}_{2} \mathrm{O}\right) ; 7.04(\mathrm{~d}, 1 \mathrm{H}, J=8.1 \mathrm{~Hz}$, $\left.\mathrm{H}-2^{\prime}\right) ; 7.15\left(\mathrm{~d}, 1 \mathrm{H}, J=8 \mathrm{~Hz}, \mathrm{H}-5^{\prime}\right) ; 7.17\left(\mathrm{~d}, 1 \mathrm{H}, J=7.9 \mathrm{~Hz}, \mathrm{H}-6^{\prime}\right) ; 7.58(\mathrm{~s}, 1 \mathrm{H}, \mathrm{CH}=) .{ }^{13} \mathrm{C}$ NMR $\left(\mathrm{DMSO}_{6}\right) \delta$ : $66.1\left(\mathrm{CH}_{2} \mathrm{NCH}_{2}\right) ; 74.4\left(\mathrm{CH}_{2} \mathrm{OCH}_{2}\right) ; 102.2\left(\mathrm{OCH}_{2} \mathrm{O}\right) ; 109.1\left(\mathrm{C}-3^{\prime}\right) ; 109.4\left(\mathrm{C}-5^{\prime}\right)$; $113.9(\mathrm{CH}=) ; 125.1\left(\mathrm{C}-6^{\prime}\right) ; 126.9\left(\mathrm{C}-1^{\prime}\right) ; 130.6(\mathrm{C}=, \mathrm{C}-4) ; 148.6\left(\mathrm{C}-4^{\prime}\right) ; 149.2\left(\mathrm{C}-3^{\prime}\right) ; 174.9(\mathrm{C}=\mathrm{O}$, C-4). HRMS, $m / z$ : 318.0688 found (calculated for $\mathrm{C}_{15} \mathrm{H}_{14} \mathrm{~N}_{2} \mathrm{O}_{4} \mathrm{~S},[\mathrm{M}]^{+\cdot}$ requires 318.0674).

(5Z)-5-(3,4-Dimethoxybenzylidene)-2-(morpholin-1-yl)-1,3-thiazol-4(5H)-one (5b). According to the standard procedure, $5 \mathrm{~b}$ was synthesized at $80{ }^{\circ} \mathrm{C}$ (power: $80 \mathrm{~W}$ ) after a reaction time of $25 \mathrm{~min}$ from (5Z)-5-(3,4-dimethoxybenzylidene)-2-thioxo-1,3-thiazolidin-4-one 3d (141 mg, $0.5 \mathrm{mmol})$ and commercial morpholine $4 \mathrm{a}(131 \mu \mathrm{L}, 131 \mathrm{mg}, 1.5 \mathrm{mmol})$ in 64\% yield $\left(107 \mathrm{mg}\right.$ ) as light-yellow powder; $\mathrm{mp}>260{ }^{\circ} \mathrm{C} .{ }^{1} \mathrm{H}$ NMR (DMSO-d 6 ) $\delta: 3.73$ (m, 4H, $\left.\mathrm{CH}_{2} \mathrm{NCH}_{2}\right) ; 3.74\left(\mathrm{~s}, 3 \mathrm{H}, \mathrm{OCH}_{3}\right) ; 3.81\left(\mathrm{~s}, 3 \mathrm{H}, \mathrm{OCH}_{3}\right) ; 3.90\left(\mathrm{~m}, 2 \mathrm{H}, \mathrm{CH}_{2} \mathrm{OCH}_{2}\right) ; 7.04(\mathrm{~d}, 1 \mathrm{H}$, $\left.J=8.1 \mathrm{~Hz}, \mathrm{H}-2^{\prime}\right) ; 7.15\left(\mathrm{~d}, 1 \mathrm{H}, J=8 \mathrm{~Hz}, \mathrm{H}-5^{\prime}\right) ; 7.17\left(\mathrm{~d}, 1 \mathrm{H}, J=7.9 \mathrm{~Hz}, \mathrm{H}-6^{\prime}\right) ; 7.58(\mathrm{~s}, 1 \mathrm{H}, \mathrm{CH}=)$. ${ }^{13} \mathrm{C}$ NMR (DMSO-d 6 ) $\delta: 57.0\left(\mathrm{OCH}_{3}\right) ; 57.1\left(\mathrm{OCH}_{3}\right) ; 66.3\left(\mathrm{CH}_{2} \mathrm{NCH}_{2}\right) ; 74.40\left(\mathrm{CH}_{2} \mathrm{OCH}_{2}\right)$; $102.2\left(\mathrm{OCH}_{2} \mathrm{O}\right) ; 109.1\left(\mathrm{C}-2^{\prime}\right) ; 109.4\left(\mathrm{C}-5^{\prime}\right) ; 113.9(\mathrm{CH}=) ; 125.1\left(\mathrm{C}-6^{\prime}\right) ; 126.9\left(\mathrm{C}-1^{\prime}\right) ; 130.6(\mathrm{C}=$, 
C-4); $148.6\left(\mathrm{C}-4^{\prime}\right) ; 149.2\left(\mathrm{C}-3^{\prime}\right) ; 174.9(\mathrm{C}=\mathrm{O}, \mathrm{C}-4)$. HRMS, $m / z$ : 334.0970 found (calculated for $\mathrm{C}_{16} \mathrm{H}_{18} \mathrm{~N}_{2} \mathrm{O}_{4} \mathrm{~S}$, [M] $]^{+}$. requires 334.0987).

(5Z)-5-(4-Hydroxy-3-methoxybenzylidene)-2-(morpholin-1-yl)-1,3-thiazol-4(5H)-one (5c). According to the standard procedure, $5 \mathbf{c}$ was synthesized at $80{ }^{\circ} \mathrm{C}$ (power: $80 \mathrm{~W}$ ) after a reaction time of $20 \mathrm{~min}$ from (5Z)-5-(4-hydroxy-3-methoxybenzylidene)-2-thioxo-1,3thiazolidin-4-one $3 \mathbf{b}$ (134 mg, $0.5 \mathrm{mmol})$ and commercial morpholine $4 \mathbf{a}(131 \mu \mathrm{L}, 131 \mathrm{mg}$, $1.5 \mathrm{mmol})$ in $88 \%$ yield $(141 \mathrm{mg})$ as light-yellow powder; $\mathrm{mp}=251-253{ }^{\circ} \mathrm{C} .{ }^{1} \mathrm{H}$ NMR (DMSO-d $\left.)_{6}\right)$ : $: 3.46\left(\mathrm{~m}, 4 \mathrm{H}, \mathrm{CH}_{2} \mathrm{NCH}_{2}\right) ; 3.81\left(\mathrm{~s}, 3 \mathrm{H}, \mathrm{OCH}_{3}\right) ; 3.90\left(\mathrm{~m}, 2 \mathrm{H}, \mathrm{CH}_{2} \mathrm{OCH}_{2}\right) ; 7.04$ $\left(\mathrm{d}, 1 \mathrm{H}, J=8.1 \mathrm{~Hz}, \mathrm{H}-2^{\prime}\right) ; 7,15\left(\mathrm{~d}, 1 \mathrm{H}, J=8 \mathrm{~Hz}, \mathrm{H}-5^{\prime}\right) ; 7.17\left(\mathrm{~d}, 1 \mathrm{H}, J=7.9 \mathrm{~Hz}, \mathrm{H}-6^{\prime}\right) ; 7.58$ (s, $1 \mathrm{H}, \mathrm{CH}=) ; 9.57(\mathrm{br} \mathrm{s}, 1 \mathrm{H}, \mathrm{OH}) .{ }^{13} \mathrm{C}$ NMR $\left(\mathrm{DMSO}-d_{6}\right)$ 8: $58.1\left(\mathrm{OCH}_{3}\right) ; 66.1\left(\mathrm{CH}_{2} \mathrm{NCH}_{2}\right)$; $74.5\left(\mathrm{CH}_{2} \mathrm{OCH}_{2}\right) ; 109.1\left(\mathrm{C}-2^{\prime}\right) ; 109.4\left(\mathrm{C}-5^{\prime}\right) ; 113.9(\mathrm{CH}=) ; 125.1\left(\mathrm{C}-6^{\prime}\right) ; 126.9\left(\mathrm{C}-1^{\prime}\right) ; 130.6(\mathrm{C}=$, C-4); $148.6\left(\mathrm{C}-4^{\prime}\right) ; 150.4\left(\mathrm{C}-3^{\prime}\right) ; 174.9(\mathrm{C}=\mathrm{O}, \mathrm{C}-4)$. HRMS, $m / z$ : 320.0836 found (calculated for $\mathrm{C}_{15} \mathrm{H}_{16} \mathrm{~N}_{2} \mathrm{O}_{4} \mathrm{~S},[\mathrm{M}]^{+}$. requires 320.0831$)$.

(5Z)-5-(3-Hydroxy-4-methoxybenzylidene)-2-(morpholin-1-yl)-1,3-thiazol-4(5H)-one (5d). According to the standard procedure, $5 \mathrm{~d}$ was synthesized at $80{ }^{\circ} \mathrm{C}$ (power: $80 \mathrm{~W}$ ) after a reaction time of $20 \mathrm{~min}$ from (5Z)-5-(3-hydroxy-4-methoxybenzylidene)-2-thioxo-1,3thiazolidin-4-one $3 \mathbf{c}(134 \mathrm{mg}, 0.5 \mathrm{mmol})$ and commercial morpholine $4 \mathbf{a}(131 \mu \mathrm{L}, 131 \mathrm{mg}$, $1.5 \mathrm{mmol})$ in $86 \%$ yield $(138 \mathrm{mg})$ as light-yellow powder; $\mathrm{mp}=256-258{ }^{\circ} \mathrm{C} .{ }^{1} \mathrm{H}$ NMR (DMSO-d $\left.d_{6}\right) \delta: 3.45\left(\mathrm{~m}, 4 \mathrm{H}, \mathrm{CH}_{2} \mathrm{NCH}_{2}\right) ; 3.91\left(\mathrm{~s}, 3 \mathrm{H}, \mathrm{OCH}_{3}\right) ; 4.01\left(\mathrm{~m}, 2 \mathrm{H}, \mathrm{CH}_{2} \mathrm{OCH}_{2}\right) ; 7.04$ $\left(\mathrm{d}, 1 \mathrm{H}, J=8.1 \mathrm{~Hz}, \mathrm{H}-2^{\prime}\right) ; 7.15\left(\mathrm{~d}, 1 \mathrm{H}, J=8 \mathrm{~Hz}, \mathrm{H}-5^{\prime}\right) ; 7.17\left(\mathrm{~d}, 1 \mathrm{H}, J=7.9 \mathrm{~Hz}, \mathrm{H}-6^{\prime}\right) ; 7.58$ (s, $1 \mathrm{H}, \mathrm{CH}=) ; 9.54(\mathrm{br} \mathrm{s}, 1 \mathrm{H}, \mathrm{OH}) .{ }^{13} \mathrm{C}$ NMR $\left(\mathrm{DMSO}-d_{6}\right)$ ): $58.1\left(\mathrm{OCH}_{3}\right) ; 66.1\left(\mathrm{CH}_{2} \mathrm{NCH}_{2}\right)$; $74.4\left(\mathrm{CH}_{2} \mathrm{OCH}_{2}\right) ; 109.1\left(\mathrm{C}-2^{\prime}\right) ; 109.4\left(\mathrm{C}-5^{\prime}\right) ; 113.5(\mathrm{CH}=) ; 125.3\left(\mathrm{C}-6^{\prime}\right) ; 126.9\left(\mathrm{C}-1^{\prime}\right) ; 130.3(\mathrm{C}=$, C-4); $148.8\left(\mathrm{C}-4^{\prime}\right) ; 149.2\left(\mathrm{C}-3^{\prime}\right) ; 175.1(\mathrm{C}=\mathrm{O}, \mathrm{C}-4)$. HRMS, $m / z: 320.0834$ found (calculated for $\mathrm{C}_{15} \mathrm{H}_{16} \mathrm{~N}_{2} \mathrm{O}_{4} \mathrm{~S}$, [M] ${ }^{+}$. requires 320.0831).

(5Z)-5-(1,3-Benzodioxol-5-ylmethylene)-2-(piperazin-1-yl)-1,3-thiazol-4(5H)-one (5e). According to the standard procedure, $5 \mathbf{e}$ was synthesized at $80^{\circ} \mathrm{C}$ (power: $80 \mathrm{~W}$ ) after a reaction time of $60 \mathrm{~min}$ from (5Z)-5-(1,3-benzodioxol-5-ylmethylene)-2-thioxo-1,3-thiazolidin-4-one 3a $(132 \mathrm{mg}, 0.5 \mathrm{mmol})$ and commercial piperazine $4 \mathrm{~d}$ (129 mg, $1.5 \mathrm{mmol})$ in 78\% yield (124 mg) as light-yellow powder; $\mathrm{mp}>260{ }^{\circ} \mathrm{C} .{ }^{1} \mathrm{H}$ NMR $\left(\mathrm{DMSO}_{-} d_{6}\right) \delta: 3.75\left(\mathrm{~m}, 4 \mathrm{H}, \mathrm{CH}_{2} \mathrm{NCH}_{2}\right)$; $3.90\left(\mathrm{~m}, 4 \mathrm{H}, \mathrm{CH}_{2} \mathrm{NHCH}_{2}\right) ; 6.10\left(\mathrm{~s}, 2 \mathrm{H}, \mathrm{OCH}_{2} \mathrm{O}\right) ; 7.06\left(\mathrm{~d}, 1 \mathrm{H}, J=8.1 \mathrm{~Hz}, \mathrm{H}-2^{\prime}\right) ; 7.17(\mathrm{~d}, 1 \mathrm{H}$, $\left.J=8 \mathrm{~Hz}, \mathrm{H}-5^{\prime}\right) ; 7.15\left(\mathrm{~d}, 1 \mathrm{H}, J=7.9 \mathrm{~Hz}, \mathrm{H}-6^{\prime}\right) ; 7.56(\mathrm{~s}, 1 \mathrm{H}, \mathrm{CH}=) ; 12.58(\mathrm{br} \mathrm{s}, 1 \mathrm{H}, \mathrm{NH}) .{ }^{13} \mathrm{C}$ NMR (DMSO-d $\left.d_{6}\right) \delta$ : $66.2\left(\mathrm{CH}_{2} \mathrm{NCH}_{2}\right) ; 74.4\left(\mathrm{CH}_{2} \mathrm{NHCH}_{2}\right) ; 102.2\left(\mathrm{OCH}_{2} \mathrm{O}\right) ; 109.3\left(\mathrm{C}-2^{\prime}\right)$; $109.1\left(\mathrm{C}-5^{\prime}\right) ; 113.9(\mathrm{CH}=) ; 125.1\left(\mathrm{C}-6^{\prime}\right) ; 126.9\left(\mathrm{C}-1^{\prime}\right) ; 130.6(\mathrm{C}=, \mathrm{C}-4) ; 148.6\left(\mathrm{C}-4^{\prime}\right) ; 149.2$ $\left(\mathrm{C}-3^{\prime}\right) ; 174.9(\mathrm{C}=\mathrm{O}, \mathrm{C}-4)$. HRMS, $m / z$ : 317.0831 found (calculated for $\mathrm{C}_{15} \mathrm{H}_{15} \mathrm{~N}_{3} \mathrm{O}_{3} \mathrm{~S}$, [M] ${ }^{+}$. requires 317.0834).

(5Z)-5-(1,3-Benzodioxol-5-ylmethylene)-2-(4-N-methylpiperazin-1-yl)-1,3-thiazol-4(5H)-one (5f). According to the standard procedure, $5 \mathbf{f}$ was synthesized at $80^{\circ} \mathrm{C}$ (power: $80 \mathrm{~W}$ ) after a reaction time of $60 \mathrm{~min}$ from (5Z)-5-(1,3-benzodioxol-5-ylmethylene)-2-thioxo-1,3-thiazolidin4-one $3 \mathbf{a}(132 \mathrm{mg}, 0.5 \mathrm{mmol})$ and commercial $\mathrm{N}$-methylpiperazine $4 \mathbf{d}(166 \mu \mathrm{L}, 150 \mathrm{mg}$, $1.5 \mathrm{mmol})$ in $84 \%$ yield $(139 \mathrm{mg})$ as light-yellow powder; $\mathrm{mp}=202-204{ }^{\circ} \mathrm{C} .{ }^{1} \mathrm{H}$ NMR $\left(\mathrm{DMSO}_{-} d_{6}\right) \delta: 3.03\left(\mathrm{~S}, 3 \mathrm{H}, \mathrm{NCH}_{3}\right) ; 3.73\left(\mathrm{~m}, 4 \mathrm{H}, \mathrm{CH}_{2} \mathrm{NCH}_{2}\right) ; 3.90\left(\mathrm{~m}, 4 \mathrm{H}, \mathrm{CH}_{2} \mathrm{NMeCH}_{2}\right)$; $6.10\left(\mathrm{~s}, 2 \mathrm{H}, \mathrm{OCH}_{2} \mathrm{O}\right) ; 7.04\left(\mathrm{~d}, 1 \mathrm{H}, J=8.1 \mathrm{~Hz}, \mathrm{H}-2^{\prime}\right) ; 7.15\left(\mathrm{~d}, 1 \mathrm{H}, J=8 \mathrm{~Hz}, \mathrm{H}-6^{\prime}\right) ; 7.17(\mathrm{~d}, 1 \mathrm{H}, J$ $\left.=7.9 \mathrm{~Hz}, \mathrm{H}-6^{\prime}\right) ; 7.57(\mathrm{~s}, 1 \mathrm{H}, \mathrm{CH}=) .{ }^{13} \mathrm{C} \mathrm{NMR}\left(\mathrm{DMSO}-d_{6}\right) \delta: 36.1\left(\mathrm{NCH}_{3}\right) ; 65.1\left(\mathrm{CH}_{2} \mathrm{NCH}_{2}\right)$; $74.2\left(\mathrm{CH}_{2} \mathrm{NMeCH}_{2}\right) ; 102.2\left(\mathrm{OCH}_{2} \mathrm{O}\right) ; 109.4\left(\mathrm{C}-5^{\prime}\right) ; 113.9(\mathrm{CH}=) ; 125.4\left(\mathrm{C}-6^{\prime}\right) ; 126.2\left(\mathrm{C}-1^{\prime}\right)$; $130.6(\mathrm{C}=, \mathrm{C}-4) ; 148.1\left(\mathrm{C}-4^{\prime}\right) ; 149.6\left(\mathrm{C}-3^{\prime}\right) ; 173.6(\mathrm{C}=\mathrm{O}, \mathrm{C}-4)$. HRMS, $m / z: 331.0962$ found (calculated for $\mathrm{C}_{16} \mathrm{H}_{17} \mathrm{~N}_{3} \mathrm{O}_{3} \mathrm{~S}$, [M] ${ }^{+}$. requires 331.0991).

(5Z)-5-(1,3-Benzodioxol-5-ylmethylene)-2-(thiomorpholin-1-yl)-1,3-thiazol-4(5H)-one (5g). According to the standard procedure, $5 \mathrm{~g}$ was synthesized at $80^{\circ} \mathrm{C}$ (power: $80 \mathrm{~W}$ ) after a reaction time of $30 \mathrm{~min}$ from (5Z)-5-(1,3-benzodioxol-5-ylmethylene)-2-thioxo-1,3-thiazolidin-4one $3 \mathbf{a}(132 \mathrm{mg}, 0.5 \mathrm{mmol})$ and commercial thiomorpholine $4 \mathbf{b}(150 \mu \mathrm{L}, 154 \mathrm{mg}, 1.5 \mathrm{mmol})$ in $80 \%$ yield $(134 \mathrm{mg})$ as light-yellow powder; $\mathrm{mp}=204-208{ }^{\circ} \mathrm{C} .{ }^{1} \mathrm{H}$ NMR (DMSO- $\left.d_{6}\right)$ ঠ: $3.79\left(\mathrm{~m}, 4 \mathrm{H}, \mathrm{CH}_{2} \mathrm{NCH}_{2}\right) ; 3.90\left(\mathrm{~m}, 4 \mathrm{H}, \mathrm{CH}_{2} \mathrm{SCH}_{2}\right) ; 6.10\left(\mathrm{~s}, 2 \mathrm{H}, \mathrm{OCH}_{2} \mathrm{O}\right) ; 7.01(\mathrm{~d}, 1 \mathrm{H}$, $\left.J=8.1 \mathrm{~Hz}, \mathrm{H}-2^{\prime}\right) ; 7.16\left(\mathrm{~d}, 1 \mathrm{H}, J=8 \mathrm{~Hz}, \mathrm{H}-6^{\prime}\right) ; 7.17\left(\mathrm{~d}, 1 \mathrm{H}, J=7.8 \mathrm{~Hz}, \mathrm{H}-6^{\prime}\right) ; 7.57(\mathrm{~s}, 1 \mathrm{H}, \mathrm{CH}=)$. 
${ }^{13} \mathrm{C}$ NMR (DMSO- $\left.d_{6}\right) \delta: 67.0\left(\mathrm{CH}_{2} \mathrm{NCH}_{2}\right) ; 74.4\left(\mathrm{CH}_{2} \mathrm{SCH}_{2}\right) ; 102.7\left(\mathrm{OCH}_{2} \mathrm{O}\right) ; 109.5\left(\mathrm{C}-5^{\prime}\right)$; $114.1(\mathrm{CH}=) ; 125.1\left(\mathrm{C}-6^{\prime}\right) ; 126.9\left(\mathrm{C}-1^{\prime}\right) ; 130.8(\mathrm{C}=, \mathrm{C}-4) ; 148.6\left(\mathrm{C}-4^{\prime}\right) ; 149.2\left(\mathrm{C}-3^{\prime}\right) ; 174.9(\mathrm{C}=\mathrm{O}$, C-4). HRMS, $m / z$ : 334.0441 found (calculated for $\mathrm{C}_{15} \mathrm{H}_{14} \mathrm{~N}_{2} \mathrm{O}_{3} \mathrm{~S}_{2}$, [M] ${ }^{+}$. requires 334.0449).

(5Z)-5-(3,4-Dimethoxybenzylidene)-2-(thiomorpholin-1-yl)-1,3-thiazol-4(5H)-one (5h). According to the standard procedure, $5 \mathrm{~h}$ was synthesized at $80^{\circ} \mathrm{C}$ (power: $80 \mathrm{~W}$ ) after a reaction time of $30 \mathrm{~min}$ from (5Z)-5-(3,4-dimethoxybenzylidene)-2-thioxo-1,3-thiazolidin-4-one 3d $(141 \mathrm{mg}, 0.5 \mathrm{mmol})$ and commercial thiomorpholine $4 \mathrm{~b}(150 \mu \mathrm{L}, 154 \mathrm{mg}, 1.5 \mathrm{mmol})$ in $78 \%$ yield $(137 \mathrm{mg})$ as light-yellow powder; $\mathrm{mp}=240-242{ }^{\circ} \mathrm{C} .{ }^{1} \mathrm{H}$ NMR $\left(\right.$ DMSO- $\left.d_{6}\right) \delta: 3.73$ $\left(\mathrm{m}, 4 \mathrm{H}, \mathrm{CH}_{2} \mathrm{NCH}_{2}\right) ; 3.74\left(\mathrm{~s}, 3 \mathrm{H}, \mathrm{OCH}_{3}\right) ; 3.81\left(\mathrm{~s}, 3 \mathrm{H}, \mathrm{OCH}_{3}\right) ; 3.90\left(\mathrm{~m}, 2 \mathrm{H}, \mathrm{CH}_{2} \mathrm{SCH}_{2}\right) ; 7.04$ $\left(\mathrm{d}, 1 \mathrm{H}, J=8.1 \mathrm{~Hz}, \mathrm{H}-2^{\prime}\right) ; 7.15\left(\mathrm{~d}, 1 \mathrm{H}, J=8 \mathrm{~Hz}, \mathrm{H}-5^{\prime}\right) ; 7.17\left(\mathrm{~d}, 1 \mathrm{H}, J=7.9 \mathrm{~Hz}, \mathrm{H}-6^{\prime}\right) ; 7.60$ (s, $1 \mathrm{H}, \mathrm{CH}=) .{ }^{13} \mathrm{C}$ NMR (DMSO-d $\left.d_{6}\right)$ 8: $57.0\left(\mathrm{OCH}_{3}\right) ; 57.1\left(\mathrm{OCH}_{3}\right) ; 66.0\left(\mathrm{CH}_{2} \mathrm{NCH}_{2}\right) ; 74.4$ $\left(\mathrm{CH}_{2} \mathrm{SCH}_{2}\right) ; 109.1\left(\mathrm{C}-5^{\prime}\right) ; 113.9(\mathrm{CH}=) ; 125.1\left(\mathrm{C}-6^{\prime}\right) ; 126.9\left(\mathrm{C}-1^{\prime}\right) ; 130.6(\mathrm{C}=, \mathrm{C}-4) ; 148.6\left(\mathrm{C}-4^{\prime}\right)$; $149.2\left(\mathrm{C}-3^{\prime}\right) ; 174.9(\mathrm{C}=\mathrm{O}, \mathrm{C}-4)$. HRMS, $m / z$ : 350.0749 found (calculated for $\mathrm{C}_{16} \mathrm{H}_{18} \mathrm{~N}_{2} \mathrm{O}_{3} \mathrm{~S}_{2}$, $[\mathrm{M}]^{+\cdot}$ requires 350.0759$)$.

(5Z)-5-(1,3-Benzodioxol-5-ylmethylene)-2-(piperidin-1-yl)-1,3-thiazol-4(5H)-one (5i). According to the standard procedure, $5 \mathbf{i}$ was synthesized at $80^{\circ} \mathrm{C}$ (power: $80 \mathrm{~W}$ ) after a reaction time of $20 \mathrm{~min}$ from (5Z)-5-(1,3-benzodioxol-5-ylmethylene)-2-thioxo-1,3-thiazolidin-4-one 3a $(132 \mathrm{mg}, 0.5 \mathrm{mmol})$ and commercial piperidine $4 \mathrm{f}(149 \mu \mathrm{L}, 128 \mathrm{mg}, 1.5 \mathrm{mmol})$ in $80 \%$ yield (127 mg) as light-yellow powder; $\mathrm{mp}=201-203{ }^{\circ} \mathrm{C} .{ }^{1} \mathrm{H}$ NMR $\left(\mathrm{DMSO}-d_{6}\right) \delta: 3.79(\mathrm{~m}, 4 \mathrm{H}$, $\left.\mathrm{CH}_{2} \mathrm{NCH}_{2}\right) ; 3.90\left(\mathrm{~m}, 4 \mathrm{H}, \mathrm{CH}_{2} \mathrm{SCH}_{2}\right) ; 6.10\left(\mathrm{~s}, 2 \mathrm{H}, \mathrm{OCH}_{2} \mathrm{O}\right) ; 7.04\left(\mathrm{~d}, 1 \mathrm{H}, J=8.1 \mathrm{~Hz}, \mathrm{H}-2^{\prime}\right)$; $7.15\left(\mathrm{~d}, 1 \mathrm{H}, J=8 \mathrm{~Hz}, \mathrm{H}-5^{\prime} ; 7.17\left(\mathrm{~d}, 1 \mathrm{H}, J=7.8 \mathrm{~Hz}, \mathrm{H}-6{ }^{\prime}\right) ; 7.58(\mathrm{~s}, 1 \mathrm{H}, \mathrm{CH}=) .{ }^{13} \mathrm{C} \mathrm{NMR}\right.$ (DMSO-d 6 ) $\delta: 60.0\left(\mathrm{CH}_{2} \mathrm{CH}_{2} \mathrm{CH}_{2}\right) ; 65.9\left(\mathrm{CH}_{2} \mathrm{CH}_{2} \mathrm{CH}_{2}\right) ; 74.4\left(\mathrm{CH}_{2} \mathrm{NCH}_{2}\right) ; 102.3\left(\mathrm{OCH}_{2} \mathrm{O}\right)$; 109.1 (C-5'); $109.4\left(\mathrm{C}-5^{\prime}\right) ; 113.7(\mathrm{CH}=) ; 125.1\left(\mathrm{C}-6^{\prime}\right) ; 126.6\left(\mathrm{C}-1^{\prime}\right) ; 130.5(\mathrm{C}=, \mathrm{C}-4) ; 148.8\left(\mathrm{C}-4^{\prime}\right)$; $149.4\left(\mathrm{C}-3^{\prime}\right) ; 174.7(\mathrm{C}=\mathrm{O}, \mathrm{C}-4)$. HRMS, $m / z: 316.0860$ found (calculated for $\mathrm{C}_{16} \mathrm{H}_{16} \mathrm{~N}_{2} \mathrm{O}_{3} \mathrm{~S}$, $[\mathrm{M}]^{+}$. requires 316.0882$)$.

(5Z)-5-(1,3-Benzodioxol-5-ylmethylene)-2-[1-(1,3-benzodioxol-5-ylmethyl)piperazin-1-yl]-1,3-thiazol$4(5 \mathrm{H})$-one $(\mathbf{5 j})$. According to the standard procedure, $5 \mathbf{j}$ was synthesized at $100{ }^{\circ} \mathrm{C}$ (power: $80 \mathrm{~W}$ ) after a reaction time of $30 \mathrm{~min}$ from (5Z)-5-(1,3-benzodioxol-5-ylmethylene)-2-thioxo1,3-thiazolidin-4-one $3 a$ (132 mg, $0.5 \mathrm{mmol}$ ) and commercial 1-(1,3-benzodioxol-5-ylmethyl) piperazine $4 \mathbf{e}(330 \mathrm{mg}, 1.5 \mathrm{mmol})$ in $75 \%$ yield $(169 \mathrm{mg})$ as light-yellow powder; $\mathrm{mp}>260^{\circ} \mathrm{C}$. ${ }^{1} \mathrm{H}$ NMR (DMSO-d $\left.d_{6}\right) \delta: 3.24\left(\mathrm{~s}, 2 \mathrm{H}, \mathrm{CH}_{2} \mathrm{~N}\right) ; 3.73\left(\mathrm{~m}, 4 \mathrm{H}, \mathrm{CH}_{2} \mathrm{NCH}_{2}\right) ; 3.92\left(\mathrm{~m}, 4 \mathrm{H}, \mathrm{CH}_{2} \mathrm{NCH}_{2}\right)$; $6.12\left(\mathrm{~s}, 2 \mathrm{H}, \mathrm{OCH}_{2} \mathrm{O}\right) ; 6.15\left(\mathrm{~s}, 2 \mathrm{H}, \mathrm{OCH}_{2} \mathrm{O}\right) ; 7.06\left(\mathrm{~d}, 1 \mathrm{H}, J=8.1 \mathrm{~Hz}, \mathrm{H}-2^{\prime}\right) ; 7.09(\mathrm{~d}, 1 \mathrm{H}, J=8.1 \mathrm{~Hz}$, $\left.\mathrm{H}-2^{\prime \prime}\right) ; 7.15\left(\mathrm{~d}, 1 \mathrm{H}, J=8 \mathrm{~Hz}, \mathrm{H}-5^{\prime}\right) ; 7.16\left(\mathrm{~d}, 1 \mathrm{H}, J=8 \mathrm{~Hz}, \mathrm{H}-3^{\prime \prime}\right) ; 7.18\left(\mathrm{~d}, 1 \mathrm{H}, J=7.9 \mathrm{~Hz}, \mathrm{H}-6^{\prime}\right)$; $7.19\left(\mathrm{~d}, 1 \mathrm{H}, J=7.9 \mathrm{~Hz}, \mathrm{H}-2^{\prime \prime}\right) ; 7.59$ (s, $\left.1 \mathrm{H}, \mathrm{CH}=\right) .{ }^{13} \mathrm{C}$ NMR (DMSO-d 6 ) $\delta: 66.1\left(\mathrm{CH}_{2} \mathrm{NCH}_{2}\right)$; $74.6\left(\mathrm{CH}_{2} \mathrm{NCH}_{2}\right) ; 102.4\left(\mathrm{OCH}_{2} \mathrm{O}\right) ; 103.2\left(\mathrm{OCH}_{2} \mathrm{O}\right) ; 109.1\left(\mathrm{C}-2^{\prime}\right) ; 109.2(\mathrm{Ar}) ; 109.4\left(\mathrm{C}-5^{\prime}\right) ; 110.1$ (Ar); $113.9(\mathrm{CH}=) ; 125.3\left(\mathrm{C}-6^{\prime}\right) ; 125.6(\mathrm{Ar}) ; 126.9\left(\mathrm{C}-1^{\prime}\right) ; 127.3\left(\mathrm{C}_{\text {ipso }} \mathrm{Ar}\right) ; 130.6(\mathrm{C}=, \mathrm{C}-4) ; 148.6$ $\left(\mathrm{C}-4^{\prime}\right) ; 148.8\left(\mathrm{C}_{i p s o} \mathrm{Ar}\right) ; 149.2\left(\mathrm{C}-3^{\prime}\right) ; 149.8(\mathrm{Ar}) ; 174.9$ (C=O, C-4). HRMS, $m / z: 451.1191$ found (calculated for $\mathrm{C}_{21} \mathrm{H}_{21} \mathrm{~N}_{3} \mathrm{O}_{5} \mathrm{~S}$, [M] ${ }^{+\cdot}$ requires 451.1202).

(5Z)-5-(1,3-Benzodioxol-5-ylmethylene)-2-[1-(4-fluorophenyl)piperazin-1-yl]-1,3-thiazol-4(5H)-one (5k). According to the standard procedure, 5k was synthesized at $120^{\circ} \mathrm{C}$ (power: $150 \mathrm{~W}$ ) after a reaction time of $30 \mathrm{~min}$ from (5Z)-5-(1,3-benzodioxol-5-ylmethylene)-2-thioxo-1,3thiazolidin-4-one $3 \mathrm{a}(132 \mathrm{mg}, 0.5 \mathrm{mmol})$ and commercial 1-(4-fluorophenyl)piperazine $4 \mathrm{~g}$ (270 mg, $1.5 \mathrm{mmol}$ ) in $72 \%$ yield $\left(148 \mathrm{mg}\right.$ ) as light-yellow powder; $\mathrm{mp}>260{ }^{\circ} \mathrm{C}$. ${ }^{1} \mathrm{H}$ NMR (DMSO-d $\left.d_{6}\right) \delta: 3.71\left(\mathrm{~m}, 4 \mathrm{H}, \mathrm{CH}_{2} \mathrm{NCH}_{2}\right) ; 3.90\left(\mathrm{~m}, 4 \mathrm{H}, \mathrm{CH}_{2} \mathrm{NCH}_{2}\right) ; 6.10\left(\mathrm{~s}, 2 \mathrm{H}, \mathrm{OCH}_{2} \mathrm{O}\right) ; 7.04$ $\left(\mathrm{d}, 1 \mathrm{H}, J=8 \mathrm{~Hz}, \mathrm{H}-2^{\prime}\right) ; 7.12\left(\mathrm{~d}, 2 \mathrm{H}, J=8.1 \mathrm{~Hz}, \mathrm{H}-2^{\prime \prime}\right) ; 7.15\left(\mathrm{~d}, 1 \mathrm{H}, J=8 \mathrm{~Hz}, \mathrm{H}-5^{\prime}\right) ; 7.16(\mathrm{~d}$, $1 \mathrm{H}, J=7.9 \mathrm{~Hz}, \mathrm{H}-6) ; 7.18$ (d, $\left.1 \mathrm{H}, J=7.9 \mathrm{~Hz}, \mathrm{H}-3{ }^{\prime \prime}\right) ; 7.56$ (s, $\left.1 \mathrm{H}, \mathrm{CH}=\right) .{ }^{13} \mathrm{C}$ NMR (DMSO-d $d_{6}$ ) ঠ: $65.9\left(\mathrm{CH}_{2} \mathrm{NCH}_{2}\right) ; 74.4\left(\mathrm{CH}_{2} \mathrm{NCH}_{2}\right) ; 102.7\left(\mathrm{OCH}_{2} \mathrm{O}\right) ; 109.4\left(\mathrm{C}-2^{\prime}\right) ; 109.2\left(\mathrm{C}_{\text {ortho }} \mathrm{Ar}\right) ; 109.4$ $\left(\mathrm{C}-5^{\prime}\right) ; 110.1\left(\mathrm{C}_{\text {meta }} \mathrm{Ar}\right) ; 113.7(\mathrm{CH}=) ; 125.1\left(\mathrm{C}-6^{\prime}\right) ; 125.6\left(\mathrm{C}-4^{\prime \prime}\right) ; 126.9\left(\mathrm{C}-1^{\prime}\right) ; 127.3(\mathrm{Ar}) ; 130.6$ $(\mathrm{C}=, \mathrm{C}-4) ; 148.4\left(\mathrm{C}-4^{\prime}\right) ; 148.7\left(\mathrm{C}_{i p s o} \mathrm{Ar}\right) ; 149.5\left(\mathrm{C}-3^{\prime}\right) ; 174.5$ (C=O, C-4). HRMS, m/z: 411.1021 found (calculated for $\mathrm{C}_{21} \mathrm{H}_{18} \mathrm{~N}_{3} \mathrm{O}_{3} \mathrm{~S}^{19} \mathrm{~F}$, [M] ${ }^{+}$. requires 411.1053).

(5Z)-5-(1,3-Benzodioxol-5-ylmethylene)-2-[4-(pyrimidin-2-yl)piperazin-1-yl]-1,3-thiazol-4(5H)-one (5l). According to the standard procedure, 51 was synthesized at $100{ }^{\circ} \mathrm{C}$ (power: $150 \mathrm{~W}$ ) after a reaction time of $25 \mathrm{~min}$ from (5Z)-5-(1,3-benzodioxol-5-ylmethylene)-2-thioxo-1,3- 
thiazolidin-4-one $3 a$ (132 mg, $0.5 \mathrm{mmol}$ ) and commercial 2-(1-piperazin-1-yl)pyrimidine $4 \mathrm{~h}$ $(212 \mu \mathrm{L}, 246 \mathrm{mg}, 1.5 \mathrm{mmol})$ in $80 \%$ yield $(158 \mathrm{mg})$ as light-yellow powder; $\mathrm{mp}>260{ }^{\circ} \mathrm{C} .{ }^{1} \mathrm{H}$ NMR (DMSO- $\left.d_{6}\right) \delta: 3.75\left(\mathrm{~m}, 4 \mathrm{H}, \mathrm{CH}_{2} \mathrm{NCH}_{2}\right) ; 3.87\left(\mathrm{~m}, 4 \mathrm{H}, \mathrm{CH}_{2} \mathrm{NCH}_{2}\right) ; 6.14\left(\mathrm{~s}, 2 \mathrm{H}, \mathrm{OCH}_{2} \mathrm{O}\right)$; $7.06\left(\mathrm{~d}, 1 \mathrm{H}, J=7.9 \mathrm{~Hz}, \mathrm{H}-2^{\prime}\right) ; 7.13\left(\mathrm{~d}, 1 \mathrm{H}, J=8 \mathrm{~Hz}, \mathrm{H}-5^{\prime}\right) ; 7.16\left(\mathrm{~d}, 1 \mathrm{H}, J=7.9 \mathrm{~Hz}, \mathrm{H}-6^{\prime}\right) ; 7.18$ (m, 3H, Ar); $7.61(\mathrm{~s}, 1 \mathrm{H}, \mathrm{CH}=) .{ }^{13} \mathrm{C} \mathrm{NMR}\left(\mathrm{DMSO}-d_{6}\right)$ 8: $66.0\left(\mathrm{CH}_{2} \mathrm{NCH}_{2}\right) ; 74.2\left(\mathrm{CH}_{2} \mathrm{NCH}_{2}\right)$; $102.5\left(\mathrm{OCH}_{2} \mathrm{O}\right) ; 109.2\left(\mathrm{C}-2^{\prime}\right) ; 109.4\left(\mathrm{C}-5^{\prime}\right) ; 110.1(\mathrm{Ar}) ; 113.9(\mathrm{CH}=) ; 125.2\left(\mathrm{C}-6^{\prime}\right) ; 125.6\left(\mathrm{C}_{\text {ipso }}\right.$ Ar); $126.9\left(\mathrm{C}-1^{\prime}\right) ; 130.5$ (C=, C-4); $148.6\left(\mathrm{C}-4^{\prime}\right) ; 148.8$ ( $\left.\mathrm{C}_{i p s o} \mathrm{Ar}\right) ; 149.2\left(\mathrm{C}-3^{\prime}\right) ; 174.7$ (C=O, C-4). HRMS, $m / z: 395.1006$ found (calculated for $\mathrm{C}_{19} \mathrm{H}_{17} \mathrm{~N}_{5} \mathrm{O}_{3} \mathrm{~S},[\mathrm{M}]^{+}$. requires 395.1052).

(5Z)-5-(2,3-Dihydro-benzofuran-5-ylmethylene)-2-(morpholin-4-yl)-1,3-thiazol-4(5H)-one (5m). According to the standard procedure, $5 \mathrm{~m}$ was synthesized at $80{ }^{\circ} \mathrm{C}$ (power: $90 \mathrm{~W}$ ) after a reaction time of $20 \mathrm{~min}$ from (5Z)-5-(2,3-dihydro-benzofuran-5-ylmethylene)-2-thioxo-1,3thiazolidin-4-one $3 \mathbf{g}(131 \mathrm{mg}, 0.5 \mathrm{mmol})$ and commercial morpholine $4 \mathrm{a}(131 \mu \mathrm{L}, 131 \mathrm{mg}, 1.5$ $\mathrm{mmol}$ ) in $80 \%$ yield $\left(127 \mathrm{mg}\right.$ ) as light-yellow powder; $\mathrm{mp}=222-224{ }^{\circ} \mathrm{C} .{ }^{1} \mathrm{H} \mathrm{NMR}$ (DMSO$\left.d_{6}\right) \delta: 3.70\left(\mathrm{t}, 2 \mathrm{H}, \mathrm{J}=6.8 \mathrm{~Hz} ; \mathrm{CH}_{2} \mathrm{CH}_{2} \mathrm{O}\right) ; 3.73\left(\mathrm{~m}, 4 \mathrm{H}, \mathrm{CH}_{2} \mathrm{NCH}_{2}\right) ; 3.90(\mathrm{t}, 2 \mathrm{H}, J=6.9 \mathrm{~Hz}$; $\left.\mathrm{CH}_{2} \mathrm{CH}_{2} \mathrm{O}\right) ; 5.20\left(\mathrm{~m}, 2 \mathrm{H}, \mathrm{CH}_{2} \mathrm{OCH}_{2}\right) ; 7.04\left(\mathrm{~d}, 1 \mathrm{H}, \mathrm{J}=8.1 \mathrm{~Hz}, \mathrm{H}-2^{\prime}\right) ; 7.15\left(\mathrm{~d}, 1 \mathrm{H}, J=8 \mathrm{~Hz}, \mathrm{H}-5^{\prime}\right)$; $7.17\left(\mathrm{~d}, 1 \mathrm{H}, \mathrm{J}=7.9 \mathrm{~Hz}, \mathrm{H}-6{ }^{\prime}\right) ; 7.58(\mathrm{~s}, 1 \mathrm{H}, \mathrm{CH}=) .{ }^{13} \mathrm{C}$ NMR $\left(\mathrm{DMSO}-d_{6}\right) \delta: 29.2\left(\mathrm{CH}_{2} \mathrm{CH}_{2} \mathrm{O}\right)$; $65.9\left(\mathrm{CH}_{2} \mathrm{NCH}_{2}\right) ; 71.7\left(\mathrm{CH}_{2} \mathrm{CH}_{2} \mathrm{O}\right) ; 74.4\left(\mathrm{CH}_{2} \mathrm{OCH}_{2}\right) ; 109.1\left(\mathrm{C}-2^{\prime}\right) ; 109.5\left(\mathrm{C}-5^{\prime}\right) ; 113.9(\mathrm{CH}=)$; $125.1\left(\mathrm{C}-6^{\prime}\right) ; 126.9\left(\mathrm{C}-1^{\prime}\right) ; 130.6(\mathrm{C}=, \mathrm{C}-4) ; 148.6\left(\mathrm{C}-4^{\prime}\right) ; 149.4\left(\mathrm{C}-3^{\prime}\right) ; 174.9(\mathrm{C}=\mathrm{O}, \mathrm{C}-4)$. HRMS, $m / z: 316.0864$ found (calculated for $\mathrm{C}_{16} \mathrm{H}_{16} \mathrm{~N}_{2} \mathrm{O}_{3} \mathrm{~S}$, [M] $]^{+}$. requires 316.0882).

(5Z)-5-(2,3-Dihydro-benzofuran-5-ylmethylene)-2-(thiomorpholin-4-yl)-1,3-thiazol-4(5H)-one (5n). According to the standard procedure, 5 n was synthesized at $80{ }^{\circ} \mathrm{C}$ (power: $90 \mathrm{~W}$ ) after a reaction time of $20 \mathrm{~min}$ from (5Z)-5-(2,3-dihydro-benzofuran-5-ylmethylene)-2-thioxo-1,3thiazolidin-4-one $3 \mathbf{g}$ (131 mg, $0.5 \mathrm{mmol})$ and commercial thiomorpholine $4 \mathbf{b}(150 \mu \mathrm{L}, 154$ $\mathrm{mg}, 1.5 \mathrm{mmol})$ in $84 \%$ yield $(140 \mathrm{mg})$ as light-yellow powder; $\mathrm{mp}=230-232{ }^{\circ} \mathrm{C} .{ }^{1} \mathrm{H} \mathrm{NMR}$ $\left(\mathrm{DMSO}_{6}\right) \delta: 3.73\left(\mathrm{t}, 2 \mathrm{H}, J=6.8 \mathrm{~Hz} ; \mathrm{CH}_{2} \mathrm{CH}_{2} \mathrm{O}\right) ; 4.02\left(\mathrm{~m}, 4 \mathrm{H}, \mathrm{CH}_{2} \mathrm{NCH}_{2}\right) ; 4.09(\mathrm{~m}, 4 \mathrm{H}$, $\left.\mathrm{CH}_{2} \mathrm{SCH}_{2}\right) ; 5.22\left(\mathrm{t}, 2 \mathrm{H}, J=6.9 \mathrm{~Hz} ; \mathrm{CH}_{2} \mathrm{CH}_{2} \mathrm{O}\right) ; 7.02\left(\mathrm{~d}, 1 \mathrm{H}, J=8.1 \mathrm{~Hz}, \mathrm{H}-2^{\prime}\right) ; 7.13(\mathrm{~d}, 1 \mathrm{H}$, $\left.J=8 \mathrm{~Hz}, \mathrm{H}-5^{\prime}\right) ; 7.19\left(\mathrm{~d}, 1 \mathrm{H}, J=7.9 \mathrm{~Hz}, \mathrm{H}-6^{\prime}\right) ; 7.60(\mathrm{~s}, 1 \mathrm{H}, \mathrm{CH}=) .{ }^{13} \mathrm{C}$ NMR (DMSO-d 6$) \delta: 29.3$ $\left(\mathrm{CH}_{2} \mathrm{CH}_{2} \mathrm{O}\right) ; 66.1\left(\mathrm{CH}_{2} \mathrm{NCH}_{2}\right) ; 71.7\left(\mathrm{CH}_{2} \mathrm{SCH}_{2}\right) ; 74.4\left(\mathrm{CH}_{2} \mathrm{CH}_{2} \mathrm{O}\right) ; 108.9\left(\mathrm{C}-2^{\prime}\right) ; 109.4\left(\mathrm{C}-5^{\prime}\right)$; $113.7(\mathrm{CH}=) ; 125.2\left(\mathrm{C}-6^{\prime}\right) ; 126.9\left(\mathrm{C}-1^{\prime}\right) ; 130.7(\mathrm{C}=, \mathrm{C}-4) ; 148.4\left(\mathrm{C}-4^{\prime}\right) ; 149.2\left(\mathrm{C}-3^{\prime}\right) ; 174.6(\mathrm{C}=\mathrm{O}$, $\mathrm{C}-4)$. HRMS, $m / z$ : 332.0643 found (calculated for $\mathrm{C}_{16} \mathrm{H}_{16} \mathrm{~N}_{2} \mathrm{O}_{2} \mathrm{~S}_{2},[\mathrm{M}]^{+}$. requires 332.0653).

(5Z)-5-(2,3-Dihydro-benzofuran-5-ylmethylene)-2-(piperidin-1-yl)-1,3-thiazol-4(5H)-one (5o). According to the standard procedure, 5o was synthesized at $80{ }^{\circ} \mathrm{C}$ (power: $90 \mathrm{~W}$ ) after a reaction time of $20 \mathrm{~min}$ from (5Z)-5-(2,3-dihydro-benzofuran-5-ylmethylene)-2-thioxo-1,3thiazolidin-4-one $3 \mathrm{~g}$ (131 mg, $0.5 \mathrm{mmol})$ and commercial piperidine $4 \mathrm{f}(149 \mu \mathrm{L}, 128 \mathrm{mg}$, $1.5 \mathrm{mmol}$ ) in $86 \%$ yield (135 mg) as light-yellow powder; $\mathrm{mp}=252-254{ }^{\circ} \mathrm{C} .{ }^{1} \mathrm{H} \mathrm{NMR}$ (DMSO$\left.d_{6}\right) \delta: 3.71\left(\mathrm{~m}, 6 \mathrm{H}, \mathrm{CH}_{2}\right) ; 3.73\left(\mathrm{t}, 2 \mathrm{H}, \mathrm{J}=6.8 \mathrm{~Hz} ; \mathrm{CH}_{2} \mathrm{CH}_{2} \mathrm{O}\right) ; 4.02\left(\mathrm{~m}, 4 \mathrm{H}, \mathrm{CH}_{2} \mathrm{NCH}_{2}\right) ; 5.22$ $\left(\mathrm{t}, 2 \mathrm{H}, J=6.9 \mathrm{~Hz} ; \mathrm{CH}_{2} \mathrm{CH}_{2} \mathrm{O}\right) ; 7.06\left(\mathrm{~d}, 1 \mathrm{H}, J=8 \mathrm{~Hz}, \mathrm{H}-2^{\prime}\right) ; 7.15\left(\mathrm{~d}, 1 \mathrm{H}, J=8.2 \mathrm{~Hz}, \mathrm{H}-5^{\prime}\right) ; 7.17$ $\left(\mathrm{d}, 1 \mathrm{H}, J=7.9 \mathrm{~Hz}, \mathrm{H}-6^{\prime}\right) ; 7.56(\mathrm{~s}, 1 \mathrm{H}, \mathrm{CH}=) .{ }^{13} \mathrm{C} \mathrm{NMR}\left(\mathrm{DMSO}-d_{6}\right) \delta: 24.1\left(\mathrm{CH}_{2} \mathrm{CH}_{2} \mathrm{CH}_{2}\right)$; $29.1\left(\underline{\mathrm{CH}}_{2} \mathrm{CH}_{2} \underline{\mathrm{CH}_{2}}\right) ; 31.2\left(\underline{\mathrm{CH}}_{2} \mathrm{CH}_{2} \mathrm{O}\right) ; 66.2\left(\mathrm{CH}_{2} \mathrm{NCH}_{2}\right) ; 74.3\left(\mathrm{CH}_{2} \underline{\left.\mathrm{CH}_{2} \mathrm{O}\right)} ; 109.1\left(\mathrm{C}-2^{\prime}\right)\right.$; $109.3\left(\mathrm{C}-5^{\prime}\right) ; 113.9(\mathrm{CH}=) ; 125.1\left(\mathrm{C}-6^{\prime}\right) ; 126.8\left(\mathrm{C}-1^{\prime}\right) ; 130.6(\mathrm{C}=, \mathrm{C}-4) ; 148.6\left(\mathrm{C}-4^{\prime}\right) ; 149.3$ $\left(\mathrm{C}-3^{\prime}\right) ; 174.9$ (C=O, C-4). HRMS, $m / z$ : 314.1075 found (calculated for $\mathrm{C}_{17} \mathrm{H}_{18} \mathrm{~N}_{2} \mathrm{O}_{2} \mathrm{~S}$, [M] $]^{+}$ requires 314.1089$)$.

(5Z)-5-(2,3-Dihydro-1,4-benzodioxin-6-ylmethylene)-2-(piperidin-1-yl)-1,3-thiazol-4(5H)-one (5p). According to the standard procedure, 5 p was synthesized at $80{ }^{\circ} \mathrm{C}$ (power: $90 \mathrm{~W}$ ) after a reaction time of $20 \mathrm{~min}$ from (5Z)-5-(2,3-dihydro-1,4-benzodioxin-6-ylmethylene)-2-thioxo1,3-thiazolidin-4-one $3 f(140 \mathrm{mg}, 0.5 \mathrm{mmol})$ and commercial piperidine $4 \mathrm{f}(149 \mu \mathrm{L}, 128$ $\mathrm{mg}, 1.5 \mathrm{mmol})$ in $88 \%$ yield $(145 \mathrm{mg})$ as light-yellow powder; $\mathrm{mp}=257-259{ }^{\circ} \mathrm{C} .{ }^{1} \mathrm{H} \mathrm{NMR}$ $\left(\mathrm{DMSO}_{6} \mathrm{~d}_{6}\right) \delta: 2.93\left(\mathrm{~m}, 6 \mathrm{H}, \mathrm{CH}_{2}\right) ; 3.72\left(\mathrm{~m}, 4 \mathrm{H}, \mathrm{CH}_{2} \mathrm{NCH}_{2}\right) ; 4.28\left(\mathrm{t}, 2 \mathrm{H}, \mathrm{OCH}_{2} \mathrm{CH}_{2} \mathrm{O}\right) ; 4.30$ $\left(\mathrm{t}, 2 \mathrm{H}, \mathrm{OCH}_{2} \mathrm{CH}_{2} \mathrm{O}\right) ; 7.04\left(\mathrm{~d}, 1 \mathrm{H}, J=8.1 \mathrm{~Hz}, \mathrm{H}-2^{\prime}\right) ; 7,14\left(\mathrm{~d}, 1 \mathrm{H}, J=8 \mathrm{~Hz}, \mathrm{H}_{-} 5^{\prime}\right) ; 7.18(\mathrm{~d}$, $\left.1 \mathrm{H}, J=7.9 \mathrm{~Hz}, \mathrm{H}-6{ }^{\prime}\right) ; 7.60(\mathrm{~s}, 1 \mathrm{H}, \mathrm{CH}=) .{ }^{13} \mathrm{C} \mathrm{NMR}\left(\mathrm{DMSO}-d_{6}\right) \delta: 24.0\left(\mathrm{CH}_{2} \mathrm{CH}_{2} \mathrm{CH}_{2}\right)$; $29.0\left(\mathrm{CH}_{2} \mathrm{CH}_{2} \mathrm{CH}_{2}\right) ; 63.1\left(\mathrm{CH}_{2} \mathrm{NCH}_{2}\right) ; 64.8\left(\mathrm{OCH}_{2} \mathrm{CH}_{2} \mathrm{O}\right) ; 66.4\left(\mathrm{OCH}_{2} \mathrm{CH}_{2} \mathrm{O}\right) ; 109.2\left(\mathrm{C}-2^{\prime}\right)$; $109.4\left(\mathrm{C}-5^{\prime}\right) ; 113.7(\mathrm{CH}=) ; 125.2\left(\mathrm{C}-6^{\prime}\right) ; 126.9\left(\mathrm{C}-1^{\prime}\right) ; 130.7(\mathrm{C}=, \mathrm{C}-4) ; 148.7\left(\mathrm{C}-4^{\prime}\right) ; 149.2$ 
(C-3'); $175.1(\mathrm{C}=\mathrm{O}, \mathrm{C}-4)$. HRMS, $m / z: 330.1081$ found (calculated for $\mathrm{C}_{17} \mathrm{H}_{18} \mathrm{~N}_{2} \mathrm{O}_{3} \mathrm{~S}$, [M] ${ }^{+}$. requires 330.1038).

(5Z)-5-(2,3-Dihydro-1,4-benzodioxin-6-ylmethylene)-2-(thiomorpholin-4-yl)-1,3-thiazol-4(5H)-one $(5 q)$. According to the standard procedure, $\mathbf{5 q}$ was synthesized at $80^{\circ} \mathrm{C}$ (power: $90 \mathrm{~W}$ ) after a reaction time of $20 \mathrm{~min}$ from (5Z)-5-(2,3-dihydro-1,4-benzodioxin-6-ylmethylene)2-thioxo-1,3-thiazolidin-4-one $3 \mathrm{f}(140 \mathrm{mg}, 0.5 \mathrm{mmol})$ and commercial thiomorpholine $4 \mathrm{~b}$ $(150 \mu \mathrm{L}, 154 \mathrm{mg}, 1.5 \mathrm{mmol})$ in $80 \%$ yield $(139 \mathrm{mg})$ as light-yellow powder; $\mathrm{mp}>260^{\circ} \mathrm{C}$. ${ }^{1} \mathrm{H}$ NMR (DMSO- $\left.d_{6}\right) \delta: 3.71\left(\mathrm{~m}, 4 \mathrm{H}, \mathrm{CH}_{2} \mathrm{NCH}_{2}\right) ; 3.90\left(\mathrm{~m}, 2 \mathrm{H}, \mathrm{CH}_{2} \mathrm{SCH}_{2}\right) ; 4.27(\mathrm{t}, 2 \mathrm{H}$, $\left.\mathrm{OCH}_{2} \mathrm{CH}_{2} \mathrm{O}\right) ; 4.30\left(\mathrm{t}, 2 \mathrm{H}, \mathrm{OCH}_{2} \mathrm{CH}_{2} \mathrm{O}\right) ; 5.10\left(\mathrm{~m}, 2 \mathrm{H}, \mathrm{CH}_{2} \mathrm{OCH}_{2}\right) ; 7.01(\mathrm{~d}, 1 \mathrm{H}, J=8.2 \mathrm{~Hz}$, $\left.\mathrm{H}-2^{\prime}\right) ; 7.15\left(\mathrm{~d}, 1 \mathrm{H}, J=8 \mathrm{~Hz}, \mathrm{H}-5^{\prime}\right) ; 7.19\left(\mathrm{~d}, 1 \mathrm{H}, J=7.9 \mathrm{~Hz}, \mathrm{H}-6^{\prime}\right) ; 7.58(\mathrm{~s}, 1 \mathrm{H}, \mathrm{CH}=) .{ }^{13} \mathrm{C} \mathrm{NMR}$ (DMSO-d 6 ) $\delta$ : $64.8\left(\mathrm{OCH}_{2} \mathrm{CH}_{2} \mathrm{O}\right) ; 66.2\left(\mathrm{CH}_{2} \mathrm{NCH}_{2} \mathrm{O}\right) ; 66.6\left(\mathrm{OCH}_{2} \mathrm{CH}_{2} \mathrm{O}\right) ; 74.40\left(\mathrm{CH}_{2} \mathrm{SCH}_{2}\right)$; $102.2\left(\mathrm{OCH}_{2} \mathrm{O}\right) ; 109.0\left(\mathrm{C}-2^{\prime}\right) ; 109.4\left(\mathrm{C}-5^{\prime}\right) ; 113.9(\mathrm{CH}=) ; 125.1\left(\mathrm{C}-6^{\prime}\right) ; 126.9\left(\mathrm{C}-1^{\prime}\right) ; 130.8(\mathrm{C}=$, C-4); $148.6\left(\mathrm{C}-4^{\prime}\right) ; 149.4\left(\mathrm{C}-3^{\prime}\right) ; 174.9$ (C=O, C-4). HRMS, $m / z$ : 348.0603 found (calculated for $\mathrm{C}_{16} \mathrm{H}_{16} \mathrm{~N}_{2} \mathrm{O}_{3} \mathrm{~S}_{2}$, [M] ${ }^{+}$requires 348.0602).

3.1.6. Standard Procedure for the Preparation of (5Z)

2- $\mathrm{N}$-Heteroarylamino-5-arylidene-1,3-thiazol-4 $(5 \mathrm{H})$-one Derivatives $(\mathbf{5} \mathbf{r}-\mathbf{x})$ by Solution Phase Condensation under Microwave in the Explorer ${ }^{\circledR} 24$ Reactor

In a $10 \mathrm{~mL}$ glass tube, the $2-\mathrm{N}$-heteroarylamino-thiazolidin-4-one 8 ( $1 \mathrm{eq})$, aromatic aldehyde 2 ( 1 eq), piperidine $(0.1 \mathrm{eq})$ or sodium acetate $(0.1 \mathrm{eq})$, and glacial acetic acid (0.1-6.6 eq) were successively placed. The glass tube was placed in the Explorer ${ }^{\circledR} 24$ CEM microwave cavity (power $=300 \mathrm{~W}$ ). The mixture was irradiated at 120 or $150{ }^{\circ} \mathrm{C}$ (with a power of 100 or $200 \mathrm{~W}$ ) for 20 or $40 \mathrm{~min}$ under vigorous magnetic stirring. After microwave dielectric heating, the reaction was allowed to cool down to room temperature. To this crude mixture, $1-2 \mathrm{~mL}$ of deionized water was added, and the resulting suspension was submitted to ultrasound in a Branson 1510 apparatus at $25^{\circ} \mathrm{C}$ for $30 \mathrm{~min}$. Then, the desired insoluble compound 3 was collected by filtration, and $2 \mathrm{~mL}$ of absolute ethanol was added to this collected compound 5 . The resulting suspension was stirred vigorously under magnetic stirring for $18 \mathrm{~h}$. The desired compound 3 was finally collected by filtration and was dried under high vacuum $\left(10^{-2}\right.$ Torr) at $25^{\circ} \mathrm{C}$ for $1 \mathrm{~h}$.

(5Z)-5-Benzo[1,3]dioxol-5-ylmethylene-2-phenylamino-1,3-thiazol-4(5H)-one (5r). According to the standard procedure, $5 \mathrm{r}$ was synthesized at $150{ }^{\circ} \mathrm{C}$ with a power of $200 \mathrm{~W}$ for $20 \mathrm{~min}$ from 2-phenylamino-1,3-thiazolidin-4-one $8 \mathrm{a}(192 \mathrm{mg}, 1 \mathrm{mmol})$, piperonaldehyde 2a (150 mg, $1 \mathrm{mmol})$, piperidine $(10 \mu \mathrm{L}, 9 \mathrm{mg}, 0.1 \mathrm{mmol}, 0.1 \mathrm{eq})$, and glacial acetic acid $(6 \mu \mathrm{L}, 6 \mathrm{mg}, 0.1 \mathrm{mmol}, 0.1 \mathrm{eq})$ in $34 \%$ yield $(100 \mathrm{mg})$ as reddish powder; $\mathrm{mp}>250{ }^{\circ} \mathrm{C} .{ }^{1} \mathrm{H}$ NMR (DMSO-d $\left.d_{6}\right) \delta: 6.08\left(\mathrm{~s}, 2 \mathrm{H}, \mathrm{OCH}_{2} \mathrm{O}\right) ; 7.03-7.22(\mathrm{~m}, 5 \mathrm{H}, \mathrm{Ar}+\mathrm{CH}=) ; 7.42(\mathrm{q}, J=7.4 \mathrm{~Hz}$, $2 \mathrm{H}, \mathrm{Ar}) ; 7.56-7.78(\mathrm{~m}, 2 \mathrm{H}, \mathrm{Ar}) ; 12.21(\mathrm{br} \mathrm{s}, 1 \mathrm{H}, \mathrm{NH}) .{ }^{13} \mathrm{C} \mathrm{NMR}\left(\mathrm{DMSO}-d_{6}\right) \delta: 101.8\left(\mathrm{OCH}_{2} \mathrm{O}\right)$;

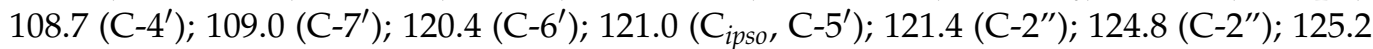
(C-4"); 127.5 (C=, C-5); 129.1 (C-3"); 129.4 (C-3"); 130.6 (CH=); $147.9\left(\mathrm{C}_{i p s o}, \mathrm{C}-1^{\prime \prime}\right) ; 148.1$ $\left(\mathrm{C}_{i p s o}, \mathrm{C}-3 \mathrm{a}^{\prime}\right) ; 148.7\left(\mathrm{C}_{i p s o}, \mathrm{C}-7 \mathrm{a}^{\prime}\right) ; 170.4(\mathrm{C}=\mathrm{N}, \mathrm{C}-2) ; 180.5$ (C=O, C-4). HRMS, $m / z: 325.0646$ found (calculated for $\mathrm{C}_{17} \mathrm{H}_{13} \mathrm{~N}_{2} \mathrm{O}_{3} \mathrm{~S}$, [M+H] ${ }^{+}$. requires 325.0647).

(5Z)-5-Benzo[1,3]dioxol-5-ylmethylene-2-(pyridin-2-yl)amino-1,3-thiazol-4(5H)-one (5s). According to the standard procedure, $5 \mathrm{~s}$ was synthesized at $120^{\circ} \mathrm{C}$ with a power of $100 \mathrm{~W}$ for $20 \mathrm{~min}$ from 2-(pyridin-2-yl)amino-1,3-thiazolidin-4-one $8 \mathbf{b}$ (50 mg, $0.26 \mathrm{mmol}$ ), piperonaldehyde $2 \mathbf{a}$ ( $39 \mathrm{mg}, 0.26 \mathrm{mmol})$, sodium acetate $(21 \mathrm{mg}, 0.26 \mathrm{mmol}, 1 \mathrm{eq})$, and glacial acetic acid $(0.1 \mathrm{~mL}, 102 \mathrm{mg}, 1.7 \mathrm{mmol}, 6.6 \mathrm{eq})$ in $90 \%$ yield $(76 \mathrm{mg})$ as green-yellowish powder; mp $>250{ }^{\circ} \mathrm{C} .{ }^{1} \mathrm{H}$ NMR $\left(\right.$ DMSO- $\left._{6}\right) \delta: 6.13\left(\mathrm{~s}, 2 \mathrm{H}, \mathrm{OCH}_{2} \mathrm{O}\right) ; 7.12(\mathrm{~d}, J=7.9 \mathrm{~Hz}, 1 \mathrm{H}$, $\mathrm{CH}=)$; 7.17-7.23 (m, 4H, H-7' $\left.{ }^{\prime} \mathrm{H}-4^{\prime}, \mathrm{H}-3^{\prime \prime}, \mathrm{H}^{-5}{ }^{\prime \prime}\right) ; 7.58\left(\mathrm{~m}, 1 \mathrm{H}, \mathrm{H}-6^{\prime}\right) ; 7.85(\mathrm{t}, J=7.6 \mathrm{~Hz}, 1 \mathrm{H}$, $\left.\mathrm{H}-4^{\prime \prime}\right) ; 8.52\left(\mathrm{~d}, J=4.1 \mathrm{~Hz}, 1 \mathrm{H}, \mathrm{H}-6{ }^{\prime \prime}\right) ; 12.39$ (br s, $\left.1 \mathrm{H}, \mathrm{NH}\right) .{ }^{13} \mathrm{C}$ NMR (DMSO- $\left.d_{6}\right) \delta: 101.9$ $\left(\mathrm{OCH}_{2} \mathrm{O}\right) ; 109.0\left(\mathrm{C}-4^{\prime}\right) ; 120.1(\mathrm{Ar}) ; 127.8(\mathrm{C}=, \mathrm{C}-5) ; 130.2(\mathrm{Ar}) ; 131.1(\mathrm{CH}=) ; 133.1(\mathrm{Ar})$; 138.9 ( $\mathrm{Ar}) ; 145.6\left(\mathrm{C}_{i p s o}, \mathrm{C}-2^{\prime \prime}\right) ; 148.0\left(\mathrm{C}_{i p s o}, \mathrm{C}-3 \mathrm{a}^{\prime}\right) ; 148.8\left(\mathrm{C}_{i p s o}, \mathrm{C}-7 \mathrm{a}^{\prime}\right) ; 163.6(\mathrm{C}=\mathrm{N}, \mathrm{C}-2)$; $187.4(\mathrm{C}=\mathrm{O}, \mathrm{C}-4)$. HRMS, $m / z: 348.0418$ found (calculated for $\mathrm{C}_{16} \mathrm{H}_{11} \mathrm{~N}_{3} \mathrm{O}_{3} \mathrm{SNa}$, [M+Na] ${ }^{+}$. requires 348.0419). 
(5Z)-5-Benzo[1,3]dioxol-5-ylmethylene-2-(pyridin-4-yl)amino-1,3-thiazol-4(5H)-one (5t). According to the standard procedure, $5 \mathbf{t}$ was synthesized at $120^{\circ} \mathrm{C}$ with a power of $100 \mathrm{~W}$ for $40 \mathrm{~min}$ from 2-(pyridin-4-yl)amino-1,3-thiazolidin-4-one 8c (150 mg, $0.78 \mathrm{mmol})$, piperonaldehyde $2 \mathrm{a}(117 \mathrm{mg}, 0.78 \mathrm{mmol})$, sodium acetate $(64 \mathrm{mg}, 0.78 \mathrm{mmol}, 1 \mathrm{eq})$, and glacial acetic acid $(295 \mu \mathrm{L}, 307 \mathrm{mg}, 5.11 \mathrm{mmol}, 6.6 \mathrm{eq})$ in $43 \%$ yield $(109 \mathrm{mg})$ as orange-yellowish powder; mp > $250{ }^{\circ} \mathrm{C}$. ${ }^{1} \mathrm{H}$ NMR $\left.\left(\mathrm{DMSO}_{-}\right)_{6}\right) \delta: 6.11\left(\mathrm{~s}, 2 \mathrm{H}, \mathrm{OCH}_{2} \mathrm{O}\right) ; 7.11\left(\mathrm{~m}, 2 \mathrm{H}, \mathrm{H}-3^{\prime \prime}\right)$; 7.13 (s, 1H, H-7'); $7.72-7.67\left(\mathrm{~m}, 3 \mathrm{H}, \mathrm{CH}=, \mathrm{H}-6^{\prime}, \mathrm{H}-4^{\prime}\right) ; 8.72\left(\mathrm{~m}, 2 \mathrm{H}, \mathrm{H}-2^{\prime \prime}\right) .{ }^{13} \mathrm{C}$ NMR

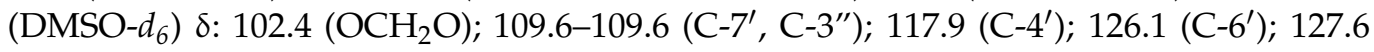
$\left(\mathrm{C}-5^{\prime}\right) ; 132.4(\mathrm{CH}=) ; 146.3-146.3\left(\mathrm{C}-2^{\prime \prime}\right) ; 149.2-148.1\left(\mathrm{C}-3 \mathrm{a}^{\prime}, \mathrm{C}-7 \mathrm{a}^{\prime}\right) ; 170.4$ (C=N, C-2); 180.5 $(\mathrm{C}=\mathrm{O}, \mathrm{C}-4)$. HRMS, $m / z: 370.0243$ found (calculated for $\mathrm{C}_{16} \mathrm{H}_{10} \mathrm{~N}_{3} \mathrm{O}_{3} \mathrm{Na}_{2} \mathrm{~S}$, [M-H+2Na] ${ }^{+}$ requires 370.0238$)$.

(5Z)-5-Benzo[1,3]dioxol-5-ylmethylene-2-(4-methoxy-phenylamino)-1,3-thiazol-4(5H)-one (5u). According to the standard procedure, $5 \mathbf{u}$ was synthesized at $120{ }^{\circ} \mathrm{C}$ with a power of $100 \mathrm{~W}$ for $20 \mathrm{~min}$ from 2-(4-methoxyphenyl)amino-1,3-thiazolidin-4-one 8d (50 mg, $0.22 \mathrm{mmol}$ ), piperonaldehyde $2 \mathbf{a}(34 \mathrm{mg}, 0.22 \mathrm{mmol})$, sodium acetate $(18 \mathrm{mg}, 0.22 \mathrm{mmol}, 1 \mathrm{eq})$, and glacial acetic acid ( $80 \mu \mathrm{L}, 87 \mathrm{mg}, 1.45 \mathrm{mmol}, 6.6 \mathrm{eq})$ in $90 \%$ yield (72 mg) as light-yellow powder; $\mathrm{mp}>250{ }^{\circ} \mathrm{C} .{ }^{1} \mathrm{H}$ NMR $\left(\mathrm{DMSO}-d_{6}\right) \delta: 3.76\left(\mathrm{~s}, 3 \mathrm{H}, \mathrm{CH}_{3} \mathrm{O}\right) ; 6.13\left(\mathrm{~s}, 2 \mathrm{H}, \mathrm{OCH}_{2} \mathrm{O}\right) ; 7.04-7.16$ $(\mathrm{m}, 5 \mathrm{H}, \mathrm{CH}=, \mathrm{Ar}) ; 7.55-7.70(\mathrm{~m}, 3 \mathrm{H}, \mathrm{Ar}) ; 11.56$ (br s, 1H, NH). ${ }^{13} \mathrm{C}$ NMR (DMSO- $\left.d_{6}\right) \delta: 55.3$ $\left(\mathrm{CH}_{3} \mathrm{O}\right) ; 101.8\left(\mathrm{OCH}_{2} \mathrm{O}\right) ; 108.7\left(\mathrm{C}-5^{\prime}\right) ; 109.0\left(\mathrm{C}-4^{\prime}\right) ; 114.2\left(\mathrm{C}-3^{\prime \prime}\right) ; 114.6\left(\mathrm{C}-3^{\prime \prime}\right) ; 122.0\left(\mathrm{C}-7^{\prime}\right) ; 123.1$ $(\mathrm{C}=, \mathrm{C}-5) ; 124.8\left(\mathrm{C}-2^{\prime \prime}\right) ; 125.1\left(\mathrm{C}-2^{\prime \prime}\right) ; 127.7\left(\mathrm{C}_{i p s o}, \mathrm{C}-1^{\prime \prime}\right) ; 128.2\left(\mathrm{C}-4^{\prime \prime}\right) ; 129.4\left(\mathrm{C}-6^{\prime}\right) ; 130.0(\mathrm{CH}=)$; 147.9 (C-3a'); $148.1\left(\mathrm{C}-7 \mathrm{a}^{\prime}\right) ; 148.7$ (C=O, C-4); 156.5 (C=N, C-2). HRMS, $m / z: 377.0574$ found (calculated for $\mathrm{C}_{18} \mathrm{H}_{14} \mathrm{~N}_{2} \mathrm{O}_{4} \mathrm{NaS}$, [M+Na] ${ }^{+}$. requires 377.0572).

(5Z)-5-Benzo[1,3]dioxol-5-ylmethylene-2-(4-chloro-phenylamino)-1,3-thiazol-4(5H)-one (5v). According to the standard procedure, $5 \mathbf{v}$ was synthesized at $120^{\circ} \mathrm{C}$ with a power of $100 \mathrm{~W}$ for $20 \mathrm{~min}$ from 2-(4-chlorophenyl)amino-1,3-thiazolidin-4-one $8 \mathbf{e}$ (50 mg, $0.22 \mathrm{mmol}$ ), piperonaldehyde $2 \mathrm{a}(34 \mathrm{mg}, 0.22 \mathrm{mmol})$, sodium acetate $(18 \mathrm{mg}, 0.22 \mathrm{mmol}, 1 \mathrm{eq})$, and glacial acetic acid $(80 \mu \mathrm{L}, 87 \mathrm{mg}, 1.45 \mathrm{mmol}, 6.6 \mathrm{eq})$ in $79 \%$ yield $(62 \mathrm{mg})$ as light-yellow powder; $\mathrm{mp}>250{ }^{\circ} \mathrm{C} .{ }^{1} \mathrm{H}$ NMR $\left(\mathrm{DMSO}_{6}\right) \delta: 6.08\left(\mathrm{~s}, 2 \mathrm{H}, \mathrm{OCH}_{2} \mathrm{O}\right) ; 7.04-7.17(\mathrm{~m}, 4 \mathrm{H}, \mathrm{Ar}) ; 7.43-7.51$ (m, 2H, Ar); 7.57-7.68 (m, 2H, Ar); 7.81 (d, J = 7.2 Hz, 1H, CH=); 11.65 (br s, $1 \mathrm{H}, \mathrm{NH}) .{ }^{13} \mathrm{C}$ NMR $\left(\mathrm{DMSO}-d_{6}\right) \delta$ : $101.8\left(\mathrm{OCH}_{2} \mathrm{O}\right) ; 108.8\left(\mathrm{C}-4^{\prime \prime}\right) ; 109.1\left(\mathrm{C}-5^{\prime}\right) ; 109.3\left(\mathrm{C}-4^{\prime}\right) ; 122.0\left(\mathrm{C}-7^{\prime}\right)$; 123.1 (C-2"); 124.9 (C-2"); 125.3 (C-5'); 127.4 (C=, C-5); 129.0 (C-1" $) ; 129.4$ (C-4"); 129.8 $\left(\mathrm{C}-6^{\prime}\right) ; 131.0(\mathrm{CH}=) ; 148.0\left(\mathrm{C}-3 \mathrm{a}^{\prime}\right) ; 148.1\left(\mathrm{C}-7 \mathrm{a}^{\prime}\right) ; 148.8(\mathrm{C}=\mathrm{O}, \mathrm{C}-4) ; 156.7(\mathrm{C}=\mathrm{N}, \mathrm{C}-2)$. HRMS, $m / z$ : 381.0079 found (calculated for $\mathrm{C}_{17} \mathrm{H}_{11} \mathrm{~N}_{2} \mathrm{O}_{3}{ }^{35} \mathrm{ClSNa},[\mathrm{M}+\mathrm{Na}]^{+}$. requires 381.0077).

(5Z)-5-(2,3-Dihydro-benzofuran-5-ylmethylene)-2-phenylamino-1,3-thiazol-4(5H)-one (5w). According to the standard procedure, $5 \mathrm{w}$ was synthesized at $150{ }^{\circ} \mathrm{C}$ with a power of $200 \mathrm{~W}$ for 20 min from 2-phenylamino-1,3-thiazolidin-4-one $8 \mathbf{a}(100 \mathrm{mg}, 0.22 \mathrm{mmol}), 2,3$-dihydro1-benzofuran-5-carbaldehyde $2 \mathrm{~b}$ (77 mg, $0.52 \mathrm{mmol})$, piperidine $(5 \mathrm{~mL}, 4 \mathrm{mg}, 0.052 \mathrm{mmol}$, $0.1 \mathrm{eq})$, and glacial acetic acid ( $3 \mu \mathrm{L}, 3 \mathrm{mg}, 0.052 \mathrm{mmol}, 0.1 \mathrm{eq})$ in $64 \%$ yield $(107 \mathrm{mg})$ as light-yellow powder; $\mathrm{mp}>250{ }^{\circ} \mathrm{C}$. ${ }^{1} \mathrm{H}$ NMR $\left(\mathrm{DMSO}_{6}\right) \delta: 3.21\left(\mathrm{~m}, 2 \mathrm{H}, \mathrm{CH}_{2}\right) ; 4.54-4.65(\mathrm{~m}$, $\left.2 \mathrm{H}, \mathrm{CH}_{2} \mathrm{O}\right) ; 6.90$ (m, 1H, H-2"); 7.03 (m, 1H, H-4"); 7.19 (t, J = 7.4 Hz, 1H, H-7'); 7.27-7.66 (m, 5H, H-4' ${ }^{\prime}$ H-6', $\left.\mathrm{H}-3^{\prime \prime}\right) ; 7.77$ (d, $\left.J=7.7 \mathrm{~Hz}, 1 \mathrm{H}, \mathrm{CH}=\right) ; 12.25$ (br s, $\left.1 \mathrm{H}, \mathrm{NH}\right) .{ }^{13} \mathrm{C} \mathrm{NMR}$

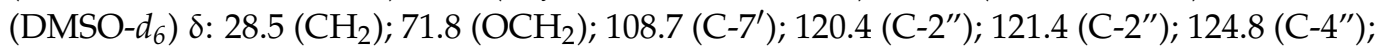
125.9 (C-3a'); 126.5 (C-6'); 128.9 (C=, C-5); 129.0 (C-1"); 129.2 (C-4'); 129.4 (C-3"); 129.9 $\left(\mathrm{C}-3^{\prime \prime}\right) ; 131.0(\mathrm{CH}=)$; $148.0\left(\mathrm{C}-3 \mathrm{a}^{\prime}\right) ; 148.1\left(\mathrm{C}-7 \mathrm{a}^{\prime}\right) ; 161.4(\mathrm{C}=\mathrm{O}, \mathrm{C}-4)$; 206.7 (C=N, C-2). HRMS, $m / z: 345.0676$ found (calculated for $\mathrm{C}_{18} \mathrm{H}_{14} \mathrm{~N}_{2} \mathrm{O}_{2} \mathrm{SNa}$, $[\mathrm{M}+\mathrm{Na}]^{+}$. requires 345.0674).

(5Z)-5-(2,3-Dihydro-benzo[1,4]dioxin-6-ylmethylene)-2-phenylamino-1,3-thiazol-4(5H)-one (5x). According to the standard procedure, $5 \mathbf{x}$ was synthesized at $120{ }^{\circ} \mathrm{C}$ with a power of $100 \mathrm{~W}$ for $20 \mathrm{~min}$ from 2-phenylamino-1,3-thiazolidin-4-one $8 \mathrm{a}$ (100 mg, $0.52 \mathrm{mmol}), 2,3$-dihydro1,4-benzodioxine-6-carbaldehyde $2 \mathrm{c}(85 \mathrm{mg}, 0.52 \mathrm{mmol})$, sodium acetate ( $43 \mathrm{mg}, 0.52 \mathrm{mmol}$, $1 \mathrm{eq})$, and glacial acetic acid $(0.2 \mu \mathrm{L}, 205 \mathrm{mg}, 3.42 \mathrm{mmol}, 6.6 \mathrm{eq})$ in $98 \%$ yield $(175 \mathrm{mg})$ as light-yellow powder; $\mathrm{mp}>250{ }^{\circ} \mathrm{C} .{ }^{1} \mathrm{H}$ NMR $\left(\mathrm{DMSO}-d_{6}\right) \delta: 4.24-4.33\left(\mathrm{~m}, 4 \mathrm{H}, \mathrm{OCH}_{2} \mathrm{CH}_{2} \mathrm{O}\right)$; 6.93-7.06 (m, 2H, H-2"); 7.12 (m, 1H, H-8'); 7.20 (t, J = 7.4 Hz, 1H, H-4"); 7.42 (m, 2H, H-3"'); $7.52\left(\mathrm{~m}, 1 \mathrm{H}, \mathrm{H}-5^{\prime}\right) ; 7.62\left(\mathrm{~m}, 1 \mathrm{H}, \mathrm{H}-7^{\prime}\right) ; 7.77$ (m, 1H, CH=); 12.26 (br s, $\left.1 \mathrm{H}, \mathrm{NH}\right) .{ }^{13} \mathrm{C} \mathrm{NMR}$ 
(DMSO-d 6 ) 8: 63.9-64.4 ( $\left.\mathrm{CH}_{2} \mathrm{CH}_{2} \mathrm{O}\right) ; 117.7\left(\mathrm{C}-5^{\prime}\right) ; 117.8\left(\mathrm{C}-8^{\prime}\right) ; 120.5\left(\mathrm{C}-2^{\prime \prime}\right) ; 121.0\left(\mathrm{C}-1^{\prime}\right)$; 121.4 (C-2"); 123.3 (C-7'); 124.9 (C-4"); 126.7 (C=, C-5); 127.1 (C-1"); 129.1 (C-3"); 129.4 (C-3"); $130.4(\mathrm{CH}=) ; 143.5\left(\mathrm{C}-4 \mathrm{a}^{\prime}\right) ; 145.1\left(\mathrm{C}-8 \mathrm{a}^{\prime}\right) ; 170.5(\mathrm{C}=\mathrm{O}, \mathrm{C}-4)$; $117.3(\mathrm{C}=\mathrm{N}, \mathrm{C}-2)$. HRMS, $m / z: 361.0623$ found (calculated for $\mathrm{C}_{18} \mathrm{H}_{14} \mathrm{~N}_{2} \mathrm{O}_{3} \mathrm{SNa}$, [M+Na] ${ }^{+}$. requires 361.0623).

\subsection{Biochemistry Part}

3.2.1. Protein Kinase Assay Buffers

Buffer A: $10 \mathrm{mM} \mathrm{MgCl}$, $1 \mathrm{mM}$ EGTA, $1 \mathrm{mM}$ DTT, $25 \mathrm{mM}$ Tris-HCl pH 7.5, $50 \mu \mathrm{g}$ heparin $/ \mathrm{mL}$.

Buffer C: $60 \mathrm{mM} \beta$-glycerophosphate, $15 \mathrm{mM}$-nitrophenyl-phosphate, $25 \mathrm{mM}$ Mops

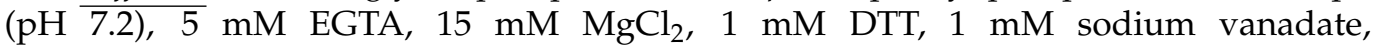
$1 \mathrm{mM}$ phenylphosphate.

\subsubsection{Kinase Preparations and Assays}

Kinase activities for each enzyme were assayed in buffer A or C, with their corresponding substrates, in the presence of $15 \mu \mathrm{M}$ ATP in a final volume of $30 \mu \mathrm{L}$. After 30-min incubation at $30^{\circ} \mathrm{C}$, the reaction was stopped by harvesting, using a FilterMate harvester (Packard), onto P81 phospho-cellulose papers (GE Healthcare, Chicago, IL, USA) which were washed in $1 \%$ phosphoric acid. Scintillation fluid was added and the radioactivity measured in a Packard counter. Blank values were subtracted and activities calculated as pmoles of phosphate incorporated for the 30-min incubation. The activities were expressed in $\%$ of the maximal activity, i.e., in the absence of inhibitors. Controls were performed with appropriate dilutions of DMSO.

$C D K 5 / p 25$ (human, recombinant) was prepared as previously described [57]. Its kinase activity was assayed in buffer $\mathrm{C}$, with $1 \mathrm{mg}$ histone $\mathrm{H} 1 / \mathrm{mL}$, in the presence of $15 \mu \mathrm{M}\left[\gamma^{33} \mathrm{P}\right]$ ATP $(3000 \mathrm{Ci} / \mathrm{mmol} ; 10 \mathrm{mCi} / \mathrm{mL})$ in a final volume of $30 \mu \mathrm{L}$. After 30 -min incubation at $30^{\circ} \mathrm{C}, 25 \mu \mathrm{L}$ aliquots of supernatant were spotted onto $2.5 \times 3 \mathrm{~cm}$ pieces of Whatman P81 phospho-cellulose paper, and, $20 \mathrm{~s}$ later, the filters were washed five times (for at least $5 \mathrm{~min}$ each time) in a solution of $10 \mathrm{~mL}$ phosphoric acid/litter of water. The wet filters were counted in the presence of $1 \mathrm{~mL}$ ACS (Amersham, UK) scintillation fluid.

DYRK1A (rat, recombinant, expressed in Escherichia coli as a GST fusion protein, provided by Dr. W. Becker) was purified by affinity chromatography on glutathioneagarose and assayed as described for CDK5/p25 using myelin basic protein $(1 \mathrm{mg} / \mathrm{mL})$ as a substrate.

Casein kinase $1(C K 1 \delta / \varepsilon)$ (porcine brain, native) was assayed with $0.67 \mu \mathrm{g}$ of CKS peptide (RRKHAAIGpSAYSITA), a CK1 specific substrate obtained from Millegen (Labege, France) [58].

GSK- $3 \alpha / \beta$ (porcine brain, native) was assayed, as described for CDK5/p25 but in Buffer A and using a GSK-3 specific substrate (GS-1: YRRAAVPPSPSLSRHSSPHQSpEDEEE) (pS stands for phosphorylated serine) [59]. GS-1 was synthesized by Millegen (Labege, France).

\subsubsection{Cell Culture and Survival Assays}

Skin diploid fibroblastic cells were provided by BIOPREDIC International Company (Rennes, France). Caco2 (Ref ECACC: 86010202), Huh-7D12 (Ref ECACC: 01042712), MDAMB-231 (Ref ECACC: 92020424), HCT-116 (Ref ECACC: 91091005), PC3 (Ref ECACC: 90112714), and NCI-H727 (Ref ECACC: 94060303) cell lines were obtained from the ECACC collection. Cells were grown according to ECACC recommendations [60]. The toxicity test of the compounds on these cells was as follows: $2 \times 10^{3}$ cells for HCT-116 cells or $4 \times 10^{3}$ for the other cells were seeded in 96-multi-well plates in triplicate and left for $24 \mathrm{~h}$ for attachment, spreading and growing. Then, cells were exposed for $48 \mathrm{~h}$ to increasing concentrations of the compounds, ranging from 0.1 to $25 \mathrm{mM}$, in a final volume of $120 \mu \mathrm{L}$ of culture medium. Cells were fixed in cooled $90 \%$ ethanol $/ 5 \%$ acetic acid solution, and nuclei were stained with Hoechst 3342 (Sigma) and counted using automated imaging 
analysis (Cellomics Arrayscan VTI/HCS Reader, Thermo/Scientific, Waltham, MA, USA). The $\mathrm{IC}_{50}$ were graphically determined.

\section{Conclusions}

All the data presented in this study demonstrate the interest and the potential of the 1,3-thiazolidin-4-one core in inhibition of the protein kinase DYRK1A. In this preliminary project of pharmacology, we have developed two series of new compounds under microwave irradiation. In the first library, the twenty-two 5-arylidene-2-thioxo-1,3thiazolidin-4-ones $3 \mathbf{a}-\mathbf{v}$ were synthesized in yields ranging from 26 to $98 \%$ by microwave irradiation assisted Knoevenagel condensation using an "open or closed vessel" approach using organic bases (propylamine, TEA, and $\mathrm{AcONa}$ ). Next, most of the compounds 3 were transformed into 2-amino-5-arylidene-1,3-thiazol-4(5H)-ones 5a-q under microwave irradiation by sulphur/nitrogen displacement with appropriate secondary cyclic amines $\mathbf{4 a}-\mathbf{h}$. This second family was completed by the preparation of seven new 2- $\mathrm{N}$-heteroarylamino-5arylidene-1,3-thiazol-4(5H)-ones $\mathbf{5} \mathbf{r}-\mathbf{x}$ from the 2- $N$-heteroarylamino-1,3-thiazolidin-4-one building blocks 8a-e under microwave irradiation (34-98\% yield). In the two libraries, all the 46 compounds 3 and 5 have been built with a Z-geometry and were evaluated against four protein kinases. Among all these compounds, nine of them turned out to be very interesting because they presented sub-micromolar inhibition activity on DYRK1A $\left(0.090 \mu \mathrm{M}>\mathrm{IC}_{50}>0.028 \mu \mathrm{M}\right)$. The most effective compounds in these two libraries are the molecules $3 \mathbf{e}$ and $5 \mathbf{s}$, as new nano-molar DYRK1A inhibitors (3e: $\mathrm{IC}_{50} 0.028 \mu \mathrm{M}$ and 5s: $\left.\mathrm{IC}_{50} 0.033 \mu \mathrm{M}\right)$. The current results are the starting point of a new larger program within our group to investigate the biological properties of these new inhibitors with potential application in Alzheimer's disease or in cancer.

Supplementary Materials: The following are available online at https:/ /www.mdpi.com/article/10.339 0/ph14111086/s1, Supporting information.

Author Contributions: Organic synthesis under microwave, K.B., S.G. and E.L.; supervision for organic synthesis under microwave, L.P. and M.R.; tumoral cell lines assays, R.L.G.; supervision for tumoral cell lines assays, T.C.; protein kinase screening, E.D. and O.L.; supervision for protein kinase screening, L.M.; supervision for organic synthesis, F.C.; supervision of project, writing-review, editing and funding acquisition of NCI contracts, J.-P.B. All authors have read and agreed to the published version of the manuscript.

Funding: This research work was funded by the "Ministère de l'Enseignement Supérieur et de la Recherche de la République Algérienne Démocratique et Populaire" (PhD fellowship for K.B.) and by the "Ministère de l'Enseignement Supérieur et de la Recherche de la République Française" (PhD fellowship for S.G.). This research was supported by the "Cancéropôle Grand Ouest" of French National Cancer Institute (contracts PRIR 04-8390 and ACI 04-2254). This research was supported by grants from the "Fondation Jérôme Lejeune" (L.M.), the "Agence Nationale pour la Recherche (ANR)" (DYRK-DOWN) (L.M.), the "Fonds Unique Interministériel" (FUI) PHARMASEA and TRIAD (L.M., J.-P.B., F.C.) projects, an FP7-KBBE-2012 grant (BlueGenics) (L.M.). This project has received funding from the European Union's Horizon 2020 research and innovation program under grant agreement No 848077. This reflects only the authors' view and the European Commission is not responsible for any use that may be made of the information it contains.

Institutional Review Board Statement: Not applicable.

Informed Consent Statement: Not applicable.

Data Availability Statement: The data presented in this study are available on request from the corresponding author.

Acknowledgments: The authors are grateful to the assistance of the staff (N. le Yondre, P. Jéhan, F. Lambert) of CMRPO analytical chemistry core facility for HRMS analysis (CRMPO platform UMS 2001 CNRS, Université de Rennes 1, Bât. 11A, Campus de Beaulieu, Rennes, France). We are thankful to Merck Eurolab Prolabo (France) for providing the Synthewave ${ }^{\circledR} 402$ microwave apparatus.

Conflicts of Interest: The authors declare no conflict of interest regarding the publication of this paper. 


\section{References}

1. Fedorov, O.; Müller, S.; Knapp, S. The (un)targeted cancer kinome. Nat. Chem. Biol. 2010, 6, 166-169. [CrossRef]

2. Dar, A.C.; Shokat, K.M. The evolution of protein kinase inhibitors from antagonists to agonists of cellular signaling. Ann. Rev. Biochem. 2011, 80, 769-795. [CrossRef]

3. Kimura, R.; Kamino, K.; Yamamoto, M.; Nuripa, A.; Kida, T.; Kazui, H.; Hashimoto, R.; Tanaka, T.; Kudo, T.; Yamagata, H.; et al The DYRK1A gene, encoded in chromosome 21 Down syndrome critical region, bridges between beta-amyloid production and tau phosphorylation in Alzheimer disease. Hum. Mol. Genet. 2007, 16, 15-23. [CrossRef] [PubMed]

4. Smith, B.; Medda, F.; Gokhale, V.; Dunckley, T.; Hulme, C. Recent Advances in the Design, Synthesis, and Biological Evaluation of Selective DYRK1A Inhibitors: A New Avenue for a Disease Modifying Treatment of Alzheimer's? ACS Chem. Neurosci. 2012, 3, 857-872. [CrossRef] [PubMed]

5. $\quad$ Ling, Y.; Wang, Z.-Q.; Xiao, Y.-A.; Zhu, C.; Shen, L.; Wang, X.-M.; Hui, Y.; Wang, X.-Y. Benzylidene 2-aminoimidazolones derivatives: Synthesis and in vitro evaluation of anti-tumor carcinoma activity. Chem. Pharm. Bull. 2013, 61, 1081-1084. [CrossRef]

6. Ionescu, A.; Dufrasne, F.; Gelbcke, M.; Jabin, I.; Kiss, R.; Lamoral-Theys, D. DYRK1A Kinase inhibitors with emphasis on cancer. Mini Rev. Med. Chem. 2012, 12, 1315-1329. [PubMed]

7. Xiao, Y.-A.; Wang, Z.-Q.; Wang, X.-M.; Hui, Y.; Ling, Y.; Wang, X.-Y.; He, L.-Q. Synthesis and in-vitro biological evaluation of novel 2-aminoimidazolinone derivatives as anti-tumor agents. Chin. Chem. Lett. 2013, 24, 727-730. [CrossRef]

8. Lindberg, M.; Meijer, L. Dual-specificity, tyrosine phosphorylation-regulated kinases (DYRKs) and cdc2-like kinases (CLKs) in human disease, an overview. Int. J. Mol. Sci. 2021, 22, 6047. [CrossRef] [PubMed]

9. Nguyen, T.L.; Fruit, C.; Hérault, Y.; Meijer, L.; Besson, T. Dual-specificity tyrosine phosphorylation-regulated kinase 1A (DYRK1A) inhibitors: A survey of recent patent literature. Expert Opin. Ther. Pat. 2017, 27, 1183-1199. [CrossRef]

10. Hagiwara, M.; Shibuya, H.; Onishi, E.; Ogawa, Y.; Hosoya, T.; Hiramatsu, T.; Yoshida, M. Pharmaceutical Composition Comprising DYRK-Inhibiting Compound. Patent WO 2010/010797 A1, 28 January 2010.

11. Fedorov, O.; Huber, K.; Eisenreich, A.; Filippakopoulos, P.; King, O.; Bullock, A.-N.; Szklarczyk, D.; Jensen, L.-J.; Fabbro, D.; Trappe, J.; et al. Specific CLK Inhibitors from a Novel Chemotype for Regulation of Alternative Splicing. Chem. Biol. 2011, 18, 67-76. [CrossRef] [PubMed]

12. Göckler, N.; Jofre, G.; Papadopoulous, C.; Soppa, U.; Tejedor, F.-J.; Becker, W. Harmine specifically inhibits protein kinase DYRK1A and interferes with neurite formation. FEBS J. 2009, 276, 6324-6337. [CrossRef] [PubMed]

13. Wang, S.; Wood, G.; Duncan, K.W.; Meades, C.; Gibson, D.; McLachlan, J.C.; Perry, A.; Blake, D.; Zheleva, D.L.; Fischer, P.M. Pyrimidin-4-yl-3,4-thione Compounds and their Use in Therapy. Patent WO 2005/042525 A1, 12 May 2005.

14. Mott, B.T.; Tanega, C.; Shen, M.; Maloney, D.J.; Shinn, P.; Leister, W.; Marugan, J.J.; Inglese, J.; Austin, C.P.; Misteli, T.; et al. Evaluation of substituted 6-arylquinazolin-4-amines as potent and selective inhibitors of cdc2-like kinases (Clk). Bioorg. Med. Chem. Lett. 2009, 19, 6700-6705. [CrossRef]

15. Rosenthal, A.S.; Tanega, C.; Shen, M.; Mott, B.T.; Bougie, J.M.; Nguyen, D.-T.; Misteli, T.; Auld, D.S.; Maloney, D.J.; Thomas, C.J. Potent and selective small molecule inhibitors of specific isoforms of Cdc2-like kinases (Clk) and dual specificity tyrosinephosphorylation-regulated kinases (Dyrk). Bioorg. Med. Chem. Lett. 2011, 21, 3152-3158. [CrossRef]

16. Leblond, B.; Casagrande, A.-S.; Désiré, L.; Foucourt, A.; Besson, T. Tricyclic Pyrimidines as Inhibitors of DYRK1A/DYRK1B as Potential Treatment for Down's Syndrome or Alzheimer's Disease. Patent WO/026806 A1, 28 February 2013.

17. Giraud, F.; Alves, G.; Debiton, E.; Nauton, L.; Thiéry, V.; Durieu, E.; Ferandin, Y.; Lozach, O.; Meijer, L.; Anizon, F.; et al. Synthesis, protein kinase inhibitory potencies, and in vitro antiproliferative activities of Meridianin derivatives. ACS J. Med. Chem. 2011, 54, 4474-4489. [CrossRef] [PubMed]

18. Echalier, A.; Bettayeb, K.; Ferandin, Y.; Lozach, O.; Clement, M.; Valette, A.; Liger, F.; Marquet, B.; Morris, J.C.; Endicott, J.A.; et al. Meriolins (3-(pyrimidin-4-yl)-7-azaindoles): Synthesis, Kinase Inhibitory Activity, Cellular Effects, and Structure of a CDK2/CyclinA/Meriolin Complex. ACS J. Med. Chem. 2008, 51, 737-751. [CrossRef] [PubMed]

19. Kassis, P.; Brzeszcz, J.; Bénéteau, V.; Lozach, O.; Meijer, L.; Le Guével, R.; Guillouzo, C.; Lewinski, K.; Bourg, S.; Colliandre, L.; et al. Synthesis and biological evaluation of new 3-(6-hydroxyindol-2-yl)-5-(Phenyl) pyridine or pyrazine V-Shaped molecules as kinase inhibitors and cytotoxic agents. Eur. J. Med. Chem. 2011, 46, 5416-5434. [CrossRef]

20. Neagoie, C.; Vedrenne, E.; Buron, F.; Mérour, J.-Y.; Rosca, S.; Bourg, S.; Lozach, O.; Meijer, L.; Baldeyrou, B.; Lansiaux, A.; et al. Synthesis of chromeno[3,4-b]indoles as Lamellarin D analogues: A novel DYRK1A inhibitor class. Eur. J. Med. Chem. 2012, 49, 379-396. [CrossRef] [PubMed]

21. Yoshida, K.; Itoyama, R.; Yamahira, M.; Tanaka, J.; Loaëc, N.; Lozach, O.; Durieu, E.; Fukuda, T.; Ishibashi, F.; Meijer, L.; et al. Synthesis, resolution, and biological evaluation of atropisomeric $(\mathrm{a} R)$ - and $(\mathrm{a} S)$-16-methyllamellarins $\mathrm{N}$ : Unique effects of the axial chirality on the selectivity of protein kinases inhibition. ACS J. Med. Chem. 2013, 56, 7289-7301. [CrossRef]

22. Davis, R.A.; Aalbersberg, W.; Meo, S.; da Rocha, R.M.; Ireland, C.M. The isolation and synthesis of polyandrocarpamines A and B. Two new 2-aminoimidazolone compounds from the Fijian ascidian, Polyandrocarpa sp. Tetrahedron Lett. 2002, 58, 3263-3269. [CrossRef]

23. Loaëc, N.; Attanasio, E.; Villiers, B.; Durieu, E.; Tahtouh, T.; Cam, M.; Davis, R.A.; Alencar, A.; Roué, M.; BourguetKondracki, M.L.; et al. Marine derived 2-aminoimidazolone alkaloids. Leucettamine B -related polyandrocarpamines inhibit mammalian and protozoan DYRK \& CLK kinases. Mar. Drugs 2017, 15, 316. 
24. Davis, R.A.; Baron, P.S.; Neve, J.E.; Cullinane, C. A microwave-assisted stereoselective synthesis of polyandrocarpamines A and B. Tetrahedron Lett. 2009, 50, 880-882. [CrossRef]

25. Lindel, T.; Hoffmann, H. Synthesis of dispacamide from the marine sponge Agelas dispar. Tetrahedron Lett. 1997, 38, 8935-8938. [CrossRef]

26. Fresneda, P.M.; Molina, P.; Sanz, M.A. A convergent approach to midpacamide and dispacamide pyrrole-imidazole marine alkaloids. Tetrahedron Lett. 2001, 42, 851-854. [CrossRef]

27. Roué, M.; Domart-Coulon, I.; Ereskovsky, A.; Djediat, C.; Perez, T.; Bourguet-Kondracki, M.-L. Cellular localization of clathridimine, an antimicrobial 2-aminoimidazole alkaloid produced by the Mediterranean calcareous sponge Clathrina clathrus. J. Nat. Prod. 2010, 73, 1277-1282. [CrossRef]

28. Chan, G.W.; Mong, S.; Hemling, M.E.; Freyer, A.J.; Offen, P.H.; De Brosse, C.W.; Sarau, H.M.; Westley, J.W. New leukotriene B4 receptor antagonist: Leucettamine A and related imidazole alkaloids from the marine sponge Leucetta microraphis. J. Nat. Prod. 1993, 56, 116-121. [CrossRef]

29. Cimino, G.; de Rosa, S.; de Stefano, S.; Mazzarella, L.; Puliti, R.; Sodano, G. Isolation and X-ray crystal structure of a novel bromo-compound from two marine sponges. Tetrahedron Lett. 1982, 23, 767-768. [CrossRef]

30. Sharma, G.M.; Buyer, J.S.; Pomerantz, M.W. Characterization of a yellow compound isolated from the marine sponge Phakellia flabellata. J. Chem. Soc. Chem. Commun. 1980, 10, 435-436. [CrossRef]

31. Williams, D.H.; Faulkner, J. Isomers and tautomers of hymenialdisine and debromohymenialdisine. Nat. Prod. Lett. 1996, 9, 57-64. [CrossRef]

32. Xu, Y.Y.; Yakushijin, K.; Horne, D.A. Synthesis of C(11)N(5) Marine sponge alkaloids: ( \pm )-hymenin, stevensine, hymenialdisine, and debromohymenialdisine. J. Org. Chem. 1997, 62, 456-464. [CrossRef]

33. Papeo, G.; Posteri, H.; Borghi, D.; Varasi, M. A new glycociamidine ring precursor: Syntheses of (Z)-hymenialdisine, (Z)-2debromohymenialdisine, and ( \pm )-endo-2-debromohymenialdisine. Org. Lett. 2005, 7, 5641-5644. [CrossRef]

34. Nguyen, T.N.; Tepe, J.J. Preparation of hymenialdisine, analogues and their evaluation as kinase inhibitors. Curr. Med. Chem. 2009, 16, 3122-3143. [CrossRef] [PubMed]

35. Meijer, L.; Thunnissen, A.M.W.H.; White, A.; Garnier, M.; Nikolic, M.; Tsai, L.H.; Walter, J.; Cleverley, K.E.; Salinas, P.C.; $\mathrm{Wu}$, Y.Z.; et al. Inhibition of cyclin-dependent kinases, GSK-3 and casein kinase 1 by hymenialdisine, a marine sponge constituent. Chem. Biol. 2000, 7, 51-63. [CrossRef]

36. Wan, Y.; Hur, W.; Cho, C.Y.; Liu, Y.; Adrian, F.J; Lozach, O.; Bach, S.; Mayer, T.; Fabbro, D.; Meijer, L.; et al. Synthesis and target identification of hymenialdisine analogs. Chem. Biol. 2004, 11, 247-259. [CrossRef] [PubMed]

37. Roué, N.; Bergman, J. Synthesis of the marine alkaloid leucettamine B. Tetrahedron 1999, 55, 14729-14738. [CrossRef]

38. Bazureau, J.-P.; Carreaux, F.; Renault, S.; Meijer, L.; Lozach, O. Imidazolone Derivatives, Preparation Method Thereof and Biological Use of Same. Patent WO 2009/05032 A2, 23 April 2009. Demande PCT/FR 2008/001152, 1 October 2008.

39. Debdab, M.; Carreaux, F.; Renault, S.; Soundararajan, M.; Fedorov, O.; Filippakopoulos, P.; Lozach, O.; Babault, L.; Tahtouh, T.; Baratte, B.; et al. Design, synthesis and biological evaluation of leucettines, a class of potent CLK and DYRK kinases inhibitors derived from the marine sponge leucettamine B. Modulation of alternative RNA splicing. ACS J. Med. Chem. 2011, 54, $4172-4186$. [CrossRef]

40. Tahtouh, T.; Elkins, J.M.; Filippakopoulos, P.; Soundararajan, M.; Burgy, G.; Durieu, E.; Cochet, C.; Schmid, R.S.; Lo, D.C.; Delhommel, F.; et al. Selectivity, cocrystal structures, and neuroprotective properties of Leucettines, a family of protein kinase inhibitors derived from the marine sponge alkaloid Leucettamine B. ACS J. Med. Chem. 2012, 55, 9312-9330. [CrossRef]

41. Mendgen, T.; Steuer, C.; Klein, C.D. Privileged Scaffolds or Promiscuous Binders: A comparative Study on Rhodanines and Related Heterocycles in Medicinal Chemistry. ACS J. Med. Chem. 2012, 55, 743-753. [CrossRef]

42. Nasr, M.N.A.; Said, S.-A. Novel 3, 3a, 4, 5, 6, 7-Hexahydroindazole and arylthiazolylpyrazoline derivatives as anti-inflammatory agents. Arch. Pharm. 2003, 336, 551-559. [CrossRef] [PubMed]

43. Martin, L.; Rabasseda, X.; Castaner, J. Darbufelone Mesilate. Drugs Futur. 1999, 24, 853-857. [CrossRef]

44. Cutshall, N.-S.; O’Day, C.; Prezhdo, M. Rhodanine derivatives as inhibitors of JSP-1. Bioorg. Med. Chem. Lett. 2005, 15, 3374-3382. [CrossRef]

45. Radi, M.; Botta, M.; Falchi, F.; Maga, G.; Baldanti, F.; Paolucci, S. Compounds with ddx3 Inhibitory Activity and Uses Thereof. Patent WO 2011/039735 A2, 7 April 2011. Demande PCT/IT 2010/054475, 4 October 2010.

46. Powers, J.-P.; Piper, D.-E.; Li, Y.; Mayorga, V.; Anzola, J.; Chen, J.-M.; Jaen, J.-C.; Lee, G.; Liu, J.; Peterson, M.G.; et al. SAR and Mode of Action of Novel Non-Nucleoside Inhibitors of Hepatitis C NS5b RNA Polymerase. ACS J. Med. Chem. 2006, 49, 1034-1046. [CrossRef]

47. Guihéneuf, S.; Paquin, L.; Carreaux, F.; Durieu, E.; Roisnel, T.; Meijer, L.; Bazureau, J.-P. New 5-ylidene rhodanine derivatives based on the Dispacamide A model. Mol. Divers. 2014, 18, 375-388. [CrossRef] [PubMed]

48. Song, Y.; Connor, D.T.; Doubleday, R.; Sorenson, R.J.; Sercel, A.; Unangst, P.C.; Roth, B.D.; Gilbertsen, R.B.; Chan, K.; Schrier, D.J.; et al. Synthesis, structure-activity relationships, and in vivo evaluations of substituted di-tert-butylphenols as a novel class of potent, selective, and orally active cyclooxygenase-2 inhibitors. 1 . Thiazolone and oxazolone series. ACS J. Med. Chem. 1999, 42, 1151-1160. [CrossRef] 
49. Lohray, B.B.; Bhushan, V.; Rao, P.B.; Madhavan, G.R.; Murali, N.; Rao, K.N.; Reddy, K.A.; Rajesh, B.M.; Reddy, P.G.; Chakrabarti, R.; et al. Novel indole containing thiazolidinedione derivatives as potent euglycemic and hypolipidaemic agents. Bioorg. Med. Chem. Lett. 1997, 7, 785-788. [CrossRef]

50. Zhou, J.F.; Zhu, F.X.; Song, Y.Z.; Zhu, Y.L. Synthesis of 5-arylalkylidenerhodanines catalyzed by tetrabutylammonium bromine in water under microwave irradiation. Arkivoc 2006, 14, 175-180. [CrossRef]

51. Safonov, I.G.; Heerding, D.A.; Keenan, R.M.; Price, A.T.; Erickson-Miller, C.L.; Hopson, C.B.; Levin, J.L.; Lord, K.A.; Tapley, P.M. New benzimidazoles as thrombopoietin receptor agonists. Bioorg. Med. Chem. Lett. 2006, 16, 1212-1216. [CrossRef]

52. Bourahla, K.; Derdour, A.; Rahmouni, M.; Carreaux, F.; Bazureau, J.-P. A practical access to novel 2-amino-5-arylidene-thiazol4-ones via sulfur/nitrogen displacement under solvent-free microwave irradiations. Tetrahedron Lett. 2007, 48, 5785-5789. [CrossRef]

53. Xia, Z.; Knaak, C.; Ma, J.; Beharry, Z.M.; McInnes, C.; Wang, W.; Kraft, A.S.; Smith, C.D. Synthesis and evaluation of novel inhibitors of Pim-1 and Pim-2 protein kinases. ACS J. Med. Chem. 2009, 52, 74-86. [CrossRef] [PubMed]

54. Unangst, P.C.; Connor, D.T.; Cetenko, W.A.; Sorenson, R.J.; Kostlan, C.R.; Sircar, J.C.; Wright, C.D.; Schrier, D.J.; Dyer, R.D. Synthesis and biological evaluation of 5-[[3,5-bis(1,1-dimethylethyl)-4-hydroxyphenyl]methylene]oxazoles, -thiazoles, and imidazoles: Novel dual 5-lipoxygenase and cyclooxygenase inhibitors with antiinflammatory activity. ACS J. Med. Chem. 1994, 37, 322-328. [CrossRef]

55. Guihéneuf, S.; Paquin, L.; Carreaux, F.; Durieu, E.; Bénédetti, H.; Le Guével, R.; Corlu, A.; Meijer, L.; Bazureau, J.-P. Microwave Assisted Organic Synthesis (MAOS) of new Dispacamide A derivatives bearing a thiazolinone platform, biological assays on inhibition of protein kinases and cell effects. Curr. Microw. Chem. 2014, 1, 33-40. [CrossRef]

56. Pulici, M.; Quartieri, F. Traceless solid-phase synthesis of 2-amino-5-alkylidene-thiazol-4-ones. Tetrahedron Lett. 2005, 46, 2387-2391. [CrossRef]

57. Leclerc, S.; Garnier, M.; Hoessel, R.; Marko, D.; Bibb, J.-A.; Snyder, G.L.; Greengard, P.; Biernat, J.; Mandelkow, E.M.; Eisenbrand, G.; et al. Indirubins inhibit glycogen synthase kinase-3 beta and CDK5/p25, two protein kinases involved in abnormal tau phosphorylation in Alzheimer's disease. A property common to most cyclin-dependent kinase inhibitors? J. Biol. Chem. 2001, 276, 251-260. [CrossRef]

58. Reinhardt, J.; Ferandin, Y.; Meijer, L. Purification of CK1 by affinity chromatography on immobilised axin. Protein Expr. Purif. 2007, 54, 101-109. [CrossRef] [PubMed]

59. Primot, A.; Baratte, B.; Gompel, M.; Borgne, A.; Liabeuf, S.; Romette, J.L.; Costantini, F.; Meijer, L. Purification of GSK-3 by affinity chromatography on immobilised axin. Protein Expr. Purif. 2000, 20, 394-404. [CrossRef]

60. Nakabayashi, H.; Taketa, K.; Miyano, K.; Yamane, T.; Sato, J. Growth of human hepatoma cell lines with differentiated functions in chemically defined medium. Cancer Res. 1982, 42, 3858-3863. [PubMed] 